\title{
An Archaeological Investigation of Late Archaic Cerros de TrincherasSites in Chihuahua, Mexico
}

Robert J. Hard

Department of Anthropology, University of Texas at San Antonio

John R. Roney

Bureau of Land Management

Follow this and additional works at: https://scholarworks.sfasu.edu/ita

Part of the American Material Culture Commons, Archaeological Anthropology Commons, Environmental Studies Commons, Other American Studies Commons, Other Arts and Humanities Commons, Other History of Art, Architecture, and Archaeology Commons, and the United States History Commons

Tell us how this article helped you.

This Article is brought to you for free and open access by the Center for Regional Heritage Research at SFA ScholarWorks. It has been accepted for inclusion in Index of Texas Archaeology: Open Access Gray Literature from the Lone Star State by an authorized editor of SFA ScholarWorks. For more information, please contact cdsscholarworks@sfasu.edu. 


\section{An Archaeological Investigation of Late Archaic Cerros de TrincherasSites in Chihuahua, Mexico}

\section{Creative Commons License}

\section{(c) (1) (8)}

This work is licensed under a Creative Commons Attribution-NonCommercial 4.0 International License 


\section{REPORT}

to

Consejo de Arqueología

Instituto Nacional de Antropología e Historia

\section{An Archaeological Investigation of Late Archaic Cerros de Trincheras Sites in Chihuahua, Mexico}

Results of the 1998 Investigations

Robert J. Hard

Center for Archaeological Research

The University of Texas at San Antonio

San Antonio, Texas 78249-0658

U.S.A.

and

John R. Roney

Bureau of Land Management

United States Department of the Interior

435 Montaño, N.E.

Albuquerque, New Mexico 87107

U.S.A.

with contributions by

Karen Adams, Susan Fish, Gayle Fritz, Kevin Hanselka, Bruce Moses,

Lee Nordt, Kari Schmidt, Steven Shackley, Bradley Vierra, and José Zapata

Translated by José Zapata

April 26, 1999

Center for Archaeological Research

Special Report, No. 25 


\section{Contents}

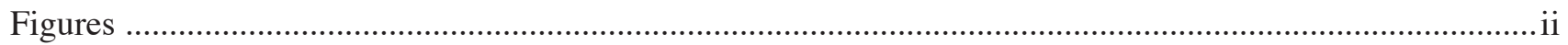

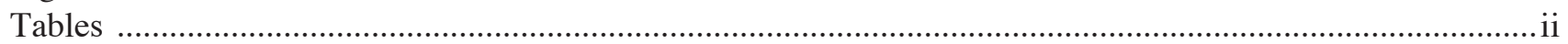

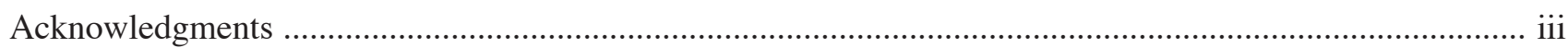

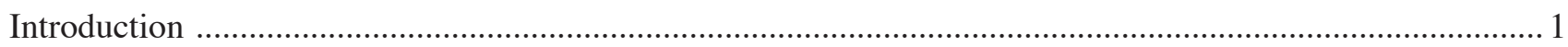

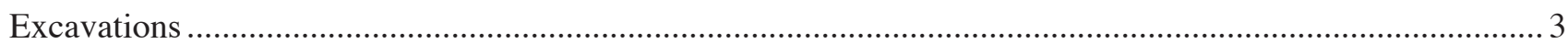

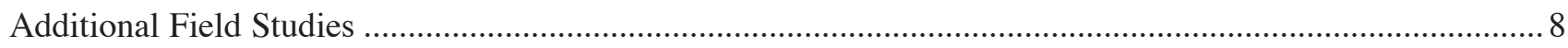

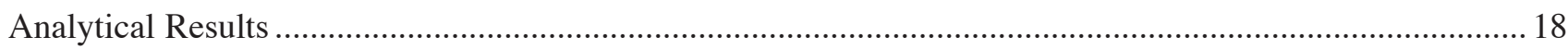

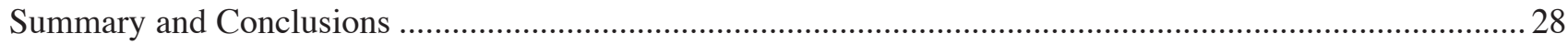

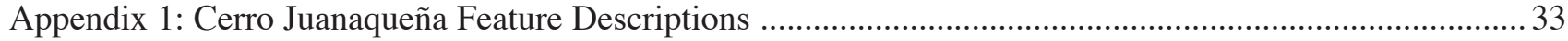

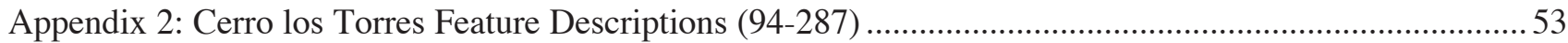

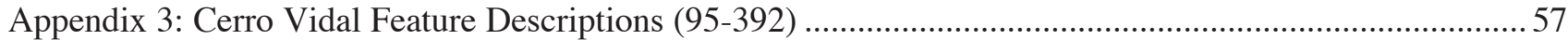

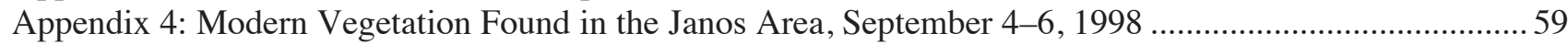

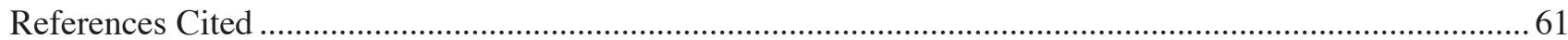




\section{Figures}

1. Aerial photograph of Cerro Juanaqueña, with the Rio Casas Grandes floodplain in foreground................... 1

2. Five cerro de trincheras sites photographed with aerial imagery..........................................................2

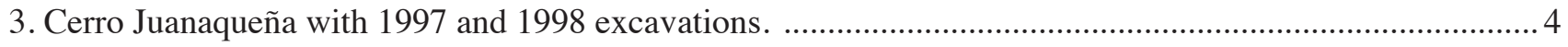

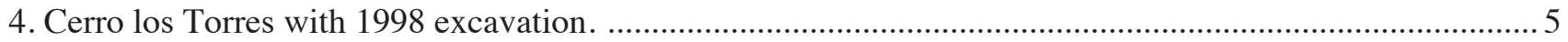

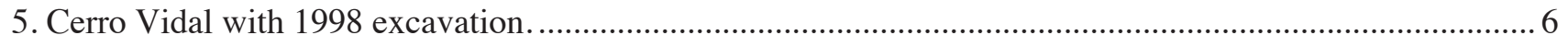

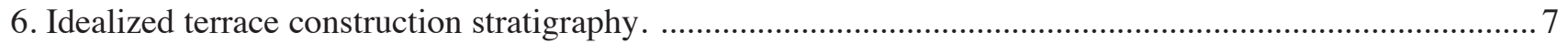

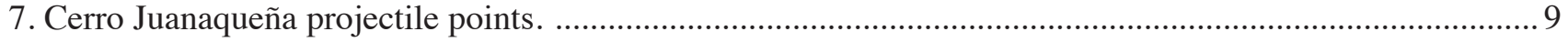

8. Geomorphic map of the Rio Casas Grandes and Rio San Pedro............................................................ 12

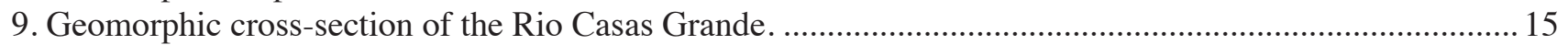

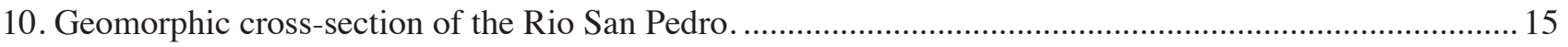

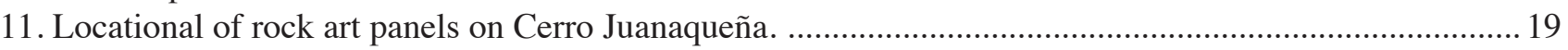

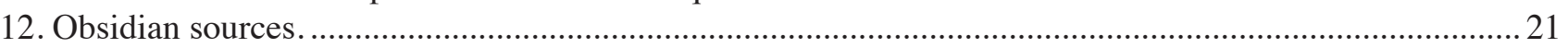

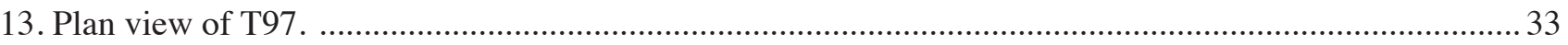

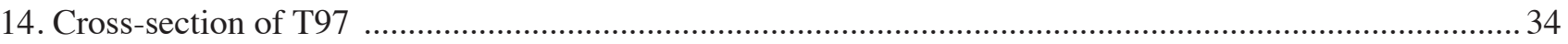

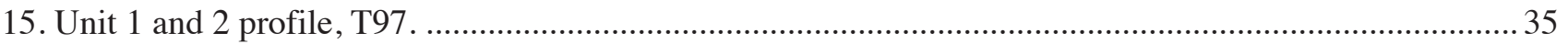

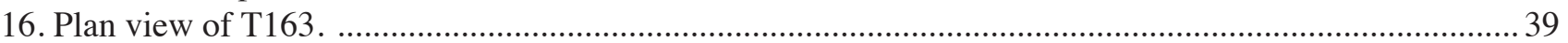

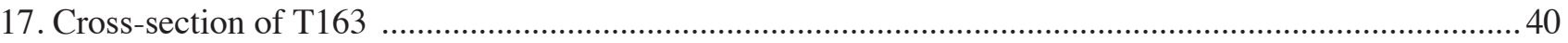

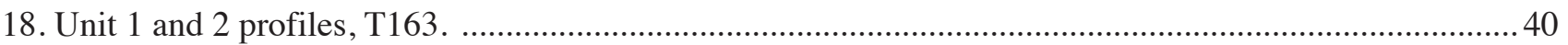

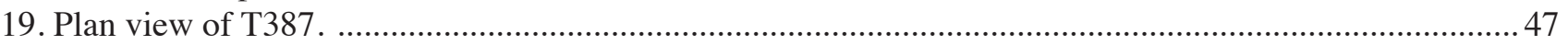

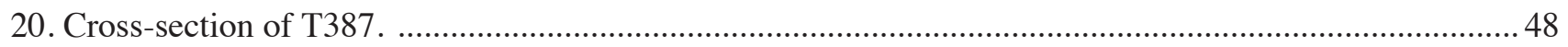

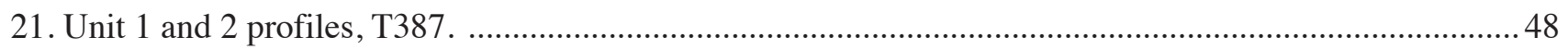

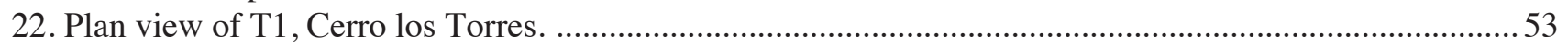

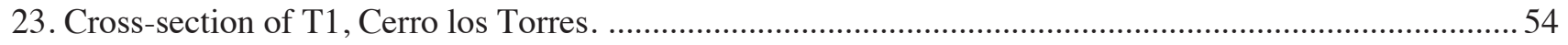

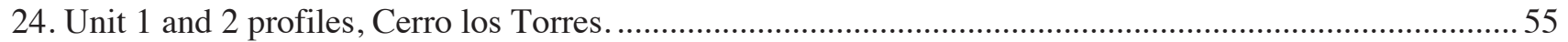

25. Rock-Ring Features on north end of Cerro Vidal. ...............................................................................56

\section{Tables}

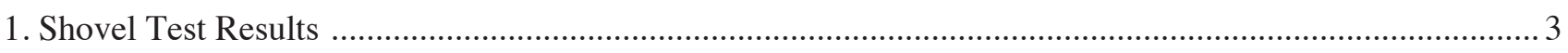

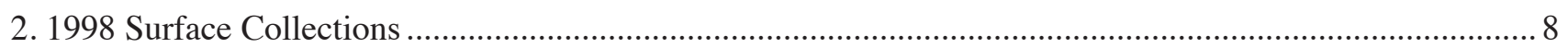

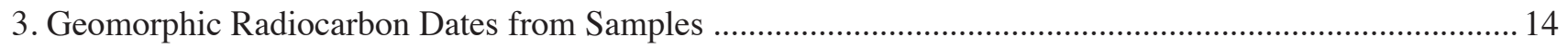

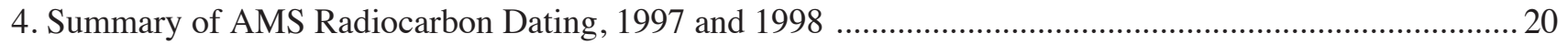

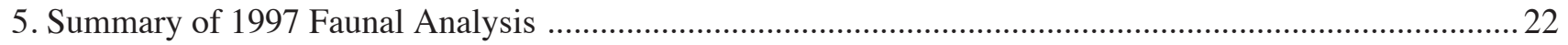

6. Number and Percentage of Identified Faunal Remains from 1997 Excavations .......................................22

7. Summary of Faunal Remains from Terrace 163, 1998 Excavations …....................................................23

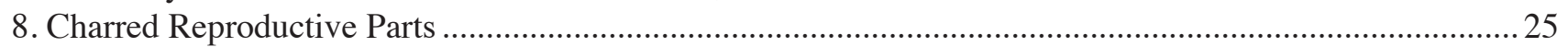

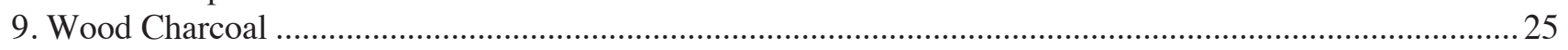

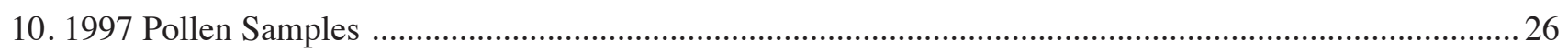

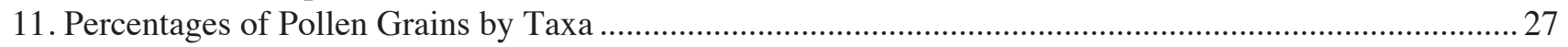




\section{Acknowledgments}

We conducted the field work reported here between June 1 and July 3, 1998, with the permission of INAH's Counsel on Archaeology (Instituto Nacional de Antropología e Historia, PA/21/98/No. 3143) and with the concurrence of the Municipalities of Casas Grandes and Janos, and the Ejidos of Casas Grandes, Hidalgo, and Janos. The study was funded by the National Science Foundation (SBR-97086210 and SBR-9809839). We could not have conducted this work without the support of these organizations and greatly appreciate the assistance their personnel have provided us. We greatly appreciate the assistance of the many individuals who have assisted us and we apologize for being unable to include everyone.

We want to thank Ing. Joaquin García Barcena, President of INAH's Counsel on Archaeology (INAH-México); Antrop. José Luis Perea González, Director of Centro INAH-Chihuahua; Lic. Arturo Peña Zazueta, Administrator of Customs, Paloma, Chihuahua; Sr. Nazario L. Prieto, Mayor of Janos; Sr. Lorenzo Barajas, President of the Janos Ejido; Sr. C. Alfonso Bustillos, Mayor of Casas Grandes; Sr. Espiridión Terrazas of Nuevo Casas Grandes; and Sr. Cruz Lara, President of the Hidalgo Ejido.

In the field, our project was greatly aided by the efforts of Jorge Bencomo, Casimiro Lucero, and Peter Wall, residents of Colonia Oaxaca and Colonia la Virginia. We also greatly appreciated the assistance and patience of Sr. Gerardo Barajas, Mayor's Secretary, Municipality of Janos; Sra. Geli Rubio and Sr. Saul Jaques, who provided our living accommodations in Janos; and Sr. Filiberto Lopez, for the many instances that he assisted us with repairs of various sorts. And for the attention, assistance, and the many delicious meals, we particularly want to thank Sra. Angelina Madrid and members of her family.

We are extremely fortunate to have some of the finest colleagues in the world whose expertise, dedication, and personal qualities have made this project successful and enjoyable from the beginning. Thanks to: Dr. Karen Adams for her wonderful ethnobotanical analyses; Dr. Susan Fish for her detailed pollen work; Dr. Gayle Fritz for her careful analysis of our cheno-am samples; Dr. Lee Nordt for his unraveling of the geomorphology of the floodplain and the trincheras; Dr. Steven Shackley for his thorough obsidian work; and Dr. Brad Vierra for his sophisticated lithic analysis.

The support of our home institutions has been essential to negotiate all the details necessary to conduct a project of this scale: The Bureau of Land Management has been very supportive of this project. At UTSA we would like to thank in particular Dwight Henderson, dean of the College of Social and Behavioral Sciences, for his support; Sherri Sunaz, administrative assistant at CAR, has performed hundreds of tasks related to the preparations for and administration of the project; Carol Hollingsworth, Kathi Kortz, and Cyndi Orth of Grants and Contracts and Mike Wright of CAR have expertly handled the many financial transactions; and Britt Bousman has served asinterim and associate director of CAR and kept CAR running smoothly while Robert J. Hard's attention and presence was focused on this project. Bruce Moses has prepared all of the excellent figures and William Bishel also has done a superb job preparing this document for publication. A UTSA Faculty Development Award was also instrumental in allowing Hard time to work on this report and other aspects of the project analysis and reporting.

Finally we want to recognize the members of our team who bore the brunt of the heat, the hill, and the hard work; but always with good cheer: Kevin Hanselka, Bruce Moses, Jennifer Nisengard, Gerry Raymond, Rudi Roney, Kari Schmidt, Cindy Tennis, José E. Zapata, and Bridget Zavala. In addition we were aided by the wonderful assistance and company of Kim Rydel (Hard) and Christopher Hard. The assistance of José E. Zapata, who has also served as expert liaison and translator for the project has also been invaluable on many fronts, large and small.

To each and everyone we are very grateful.

Robert J. Hard and John R. Roney 



\section{Introduction}

Cerro Juanaqueña is a large cerro de trincheras located in northwestern Chihuahua, in the municipio of Janos. The site was built over 3000 years ago on the summit and slopes of a 140 meter high basalt hill which overlooks the floodplain of the Rio Casas Grandes and its major tributary, the Rio San Pedro. Large constructed terraces cover an area of about 8 hectares, with over 8 kilometers of terrace wall and 108 stone circles (see Figure 1). A large number of stone artifacts are found with these features, and excavations have revealed rich midden deposits with abundant bone and carbonized plant material (Hard and Roney 1998a).

In our 1998 informe (reporting results of our 1997 field season) we described test excavations in three terraces and four stone circles, as well as mapping activities, collection of surface materials, geomorphic investigations of the Rio Casas Grandes floodplain, documentation of rock art, and reconnaissance at other similar sites.
This informe summarizes the investigations undertaken at Cerro Juanaqueña and other related sites under the oficio No. C.A. 401-36/560 (22 de mayo de 1998) authorized by the Consejo de Antropología. The project was funded in 1997 by National Science Foundation (NSF) SBR-97086210 and in 1998 by NSF SBR-9809839. Our primary objective during 1998 was to recover charcoal for radiocarbon dating and macrobotanical analysis, as well as to expand the sample of faunal materials. Our strategy was to select 10 terraces on Cerro Juanaqueña for test excavation. Descriptions of these excavations are in Appendix 1. We continued geomorphological investigations of floodplain deposits, which were begun in 1997, as well as in-field analysis of ground stone and limited surface collection. With assistance from the INAH Centro Regional in Chihuahua we also arranged to have largescale aerial photographs taken of Cerro Juanaqueña and four other nearby cerros de trincheras, as well as a part of the floodplain near Cerro Juanaqueña. Analytical activities continued, and we are able to report two additional radiocarbon dates on materials excavated in 1997, as well as preliminary results of the

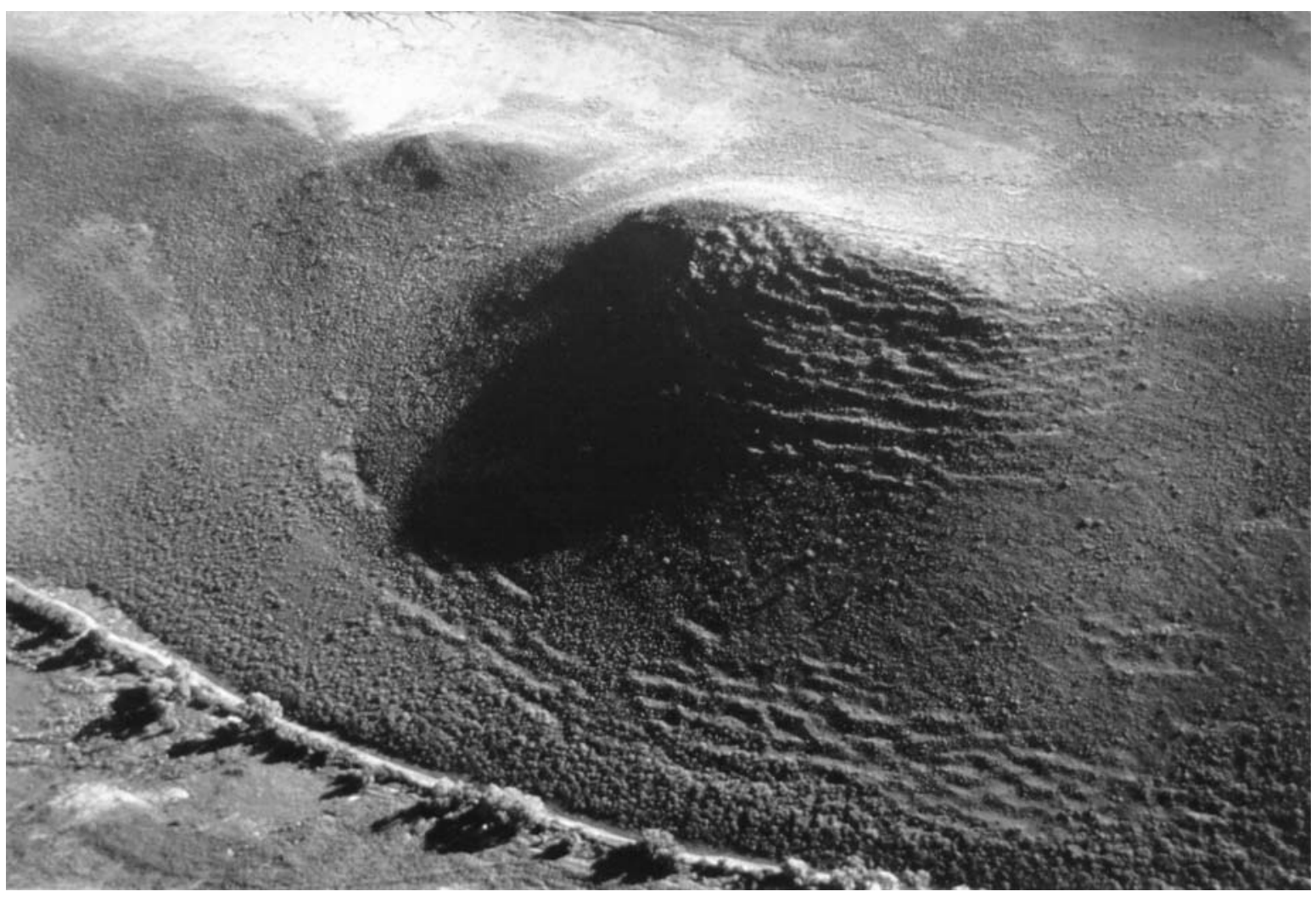

Figure 1. Aerial photograph of Cerro Juanaqueña, with the Rio Casas Grandes floodplain in foreground. View toward northwest. 
Figure 2. Five cerro de trincheras sites photographed with aerial imagery.

PAGE 2 REDACTED 
geomorphological study, pollen analysis, and lithic analysis.

In 1998 we expanded our project to include limited work at two other cerro de trincheras in the Rio Casas Grandes drainage, Cerro los Torres and Cerro Vidal (see Figure 2). Both of these sites were originally registered and mapped during Minnis and Whalen's project in 1996. Cerro los Torres is located about 20 $\mathrm{km}$ north of Nuevo Casas Grandes. The site consists of over $2 \mathrm{~km}$ of terrace walls and perhaps 20 rock rings built on an $85 \mathrm{~m}$ high isolated hill overlooking the floodplain. Although some pottery and a few arrow points have been found on Cerro los Torres, it also has dart points and other artifacts which are reminiscent of those at Cerro Juanaqueña. The terraces and stone circles are also similar to the features on Cerro Juanaqueña. For these reasons we suspect that the site was originally built and used during the Late Archaic period. This site and our test excavations there are described more fully in Appendix 2.

Cerro Vidal is a third cerro de trincheras located adjacent to the Rio Piedras Verdes 6 kilometers south of Colonia Juarez in the municipio of Casas Grandes Viejo. This site is located on an $120 \mathrm{~m}$ high hill. It includes approximately $2.3 \mathrm{~km}$ of terrace wall and about 40 rock rings. No pottery has been found, and although there are arrow points on the site, its overall similarity to Cerro Juanaqueña in terms of artifacts and form of its features suggests that it also dates to Late Archaic times. Owing to newly acquired data, this last suggestion has been reconsidered. This site and our test excavations there are described in Appendix 3.

\section{Excavations}

\section{Shovel Tests}

In 1998 we excavated nine small shovel tests at Cerro Juanaqueña, each less than $.5 \mathrm{~m} \times .5 \mathrm{~m}$ in size. These units were excavated in $10 \mathrm{~cm}$ increments and the ex- cavated soil was screened through 1/8-inch mesh screen. Artifacts and bone from these units were tabulated, but not curated. Instead they were put back into the holes as they were backfilled. The purpose of these units was to determine whether or not more extensive testing was likely to be productive in particular terraces. Positive results in these small test units led us to place larger test units in T387, T413, and R234a. Several other terraces appeared promising on the basis of surface observations but were not selected for more extensive testing because the small test pits yielded negative results (T74, T195, T213, T217, T261, and T273). The shovel tests and their results are summarized in Table 1.

Table 1. Shovel Test Results

\begin{tabular}{|l|l|l|}
\hline \multicolumn{1}{|c|}{ Feature } & \multicolumn{1}{|c|}{ Depth } & \multicolumn{1}{|c|}{ Results } \\
\hline T 74 & $30 \mathrm{~cm}$ & 6 lithics \\
\hline T 195 & $80 \mathrm{~cm}$ & 17 lithics, 1 bone \\
\hline T 213 & $40 \mathrm{~cm}$ & 11 lithics, 3 bone \\
\hline T 217 & $50 \mathrm{~cm}$ & 19 lithics, 9 bone \\
\hline T 261 & $40 \mathrm{~cm}$ & 1 lithic, 1 bone \\
\hline T 273 & $40 \mathrm{~cm}$ & Numerous lithics and bone fragments \\
\hline T 387 & $52 \mathrm{~cm}$ & 28 lithics, 11 bone, 14 charcoal \\
\hline T 413 & $50 \mathrm{~cm}$ & $\begin{array}{l}\text { A few lithics and bones, significant } \\
\text { charcoal }\end{array}$ \\
\hline R 234a & $40 \mathrm{~cm}$ & 16 lithics, 11 bone \\
\hline
\end{tabular}

\section{Test Units}

Ten terraces at Cerro Juanaqueña, one terrace Cerro los Torres, and one terrace at Cerro Vidal were selected for more intensive testing. Figures 3, 4, and 5 show maps of each site and the locations of our excavations. Appendices 1, 2, and 3 provide detailed descriptions of the individual terraces which were tested as well as the results of these excavations. Our primary objective in these test units was to obtain charcoal for radiocarbon dating and macrobotanical analysis. In addition, we hoped to expand the sample of faunal material and to expose stratigraphic profiles which would help us better understand the formation processes on Cerro Juanaqueña. The terraces were selected with several criteria in mind. First, results of the 1997 excavations suggested that bone and charcoal are not well preserved near the surface, so we attempted to select terraces which had deposits a meter 


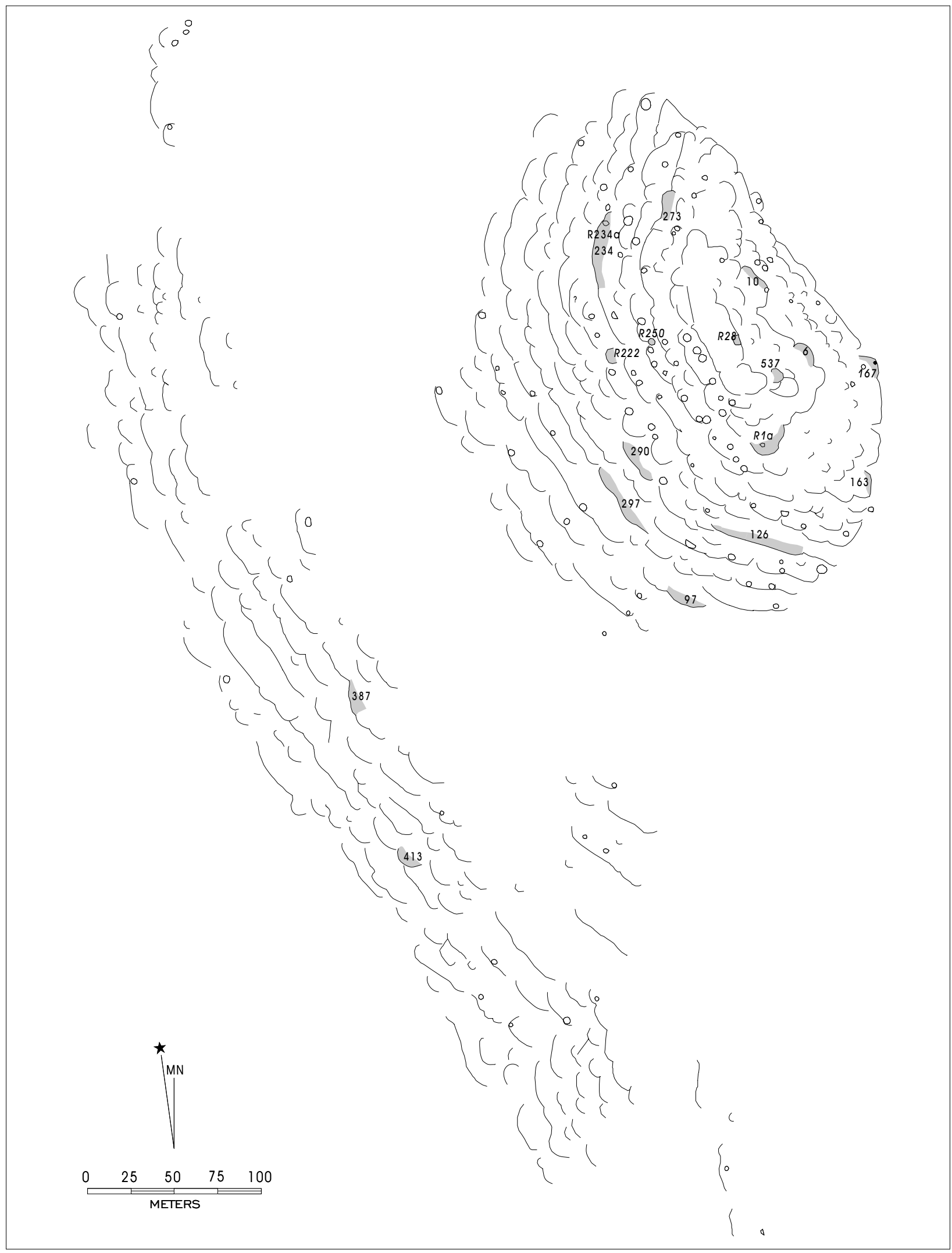

Figure 3. Cerro Juanaqueña with 1997 and 1998 excavations. 


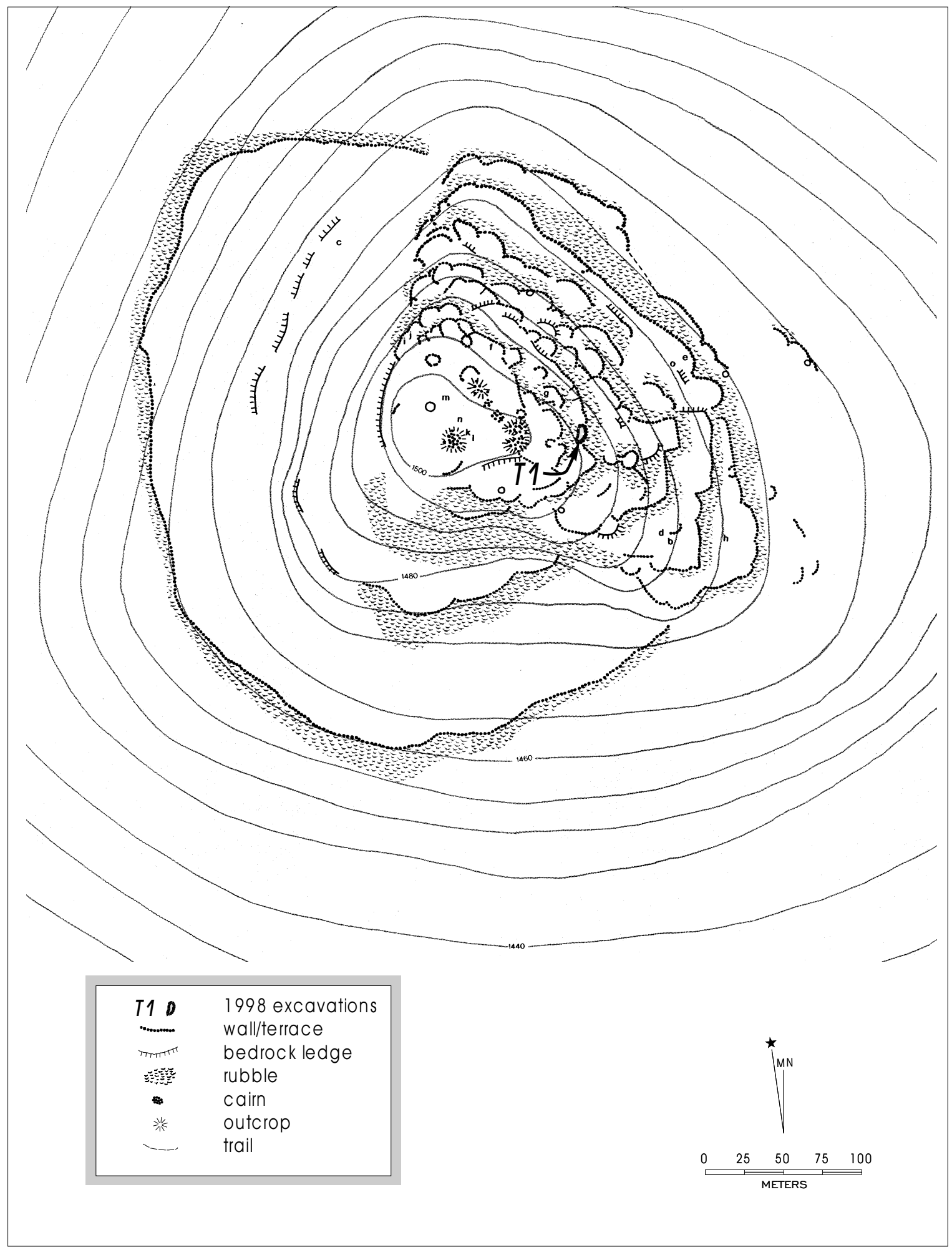

igure 4. Cerro los Torres with 1998 excavation. 


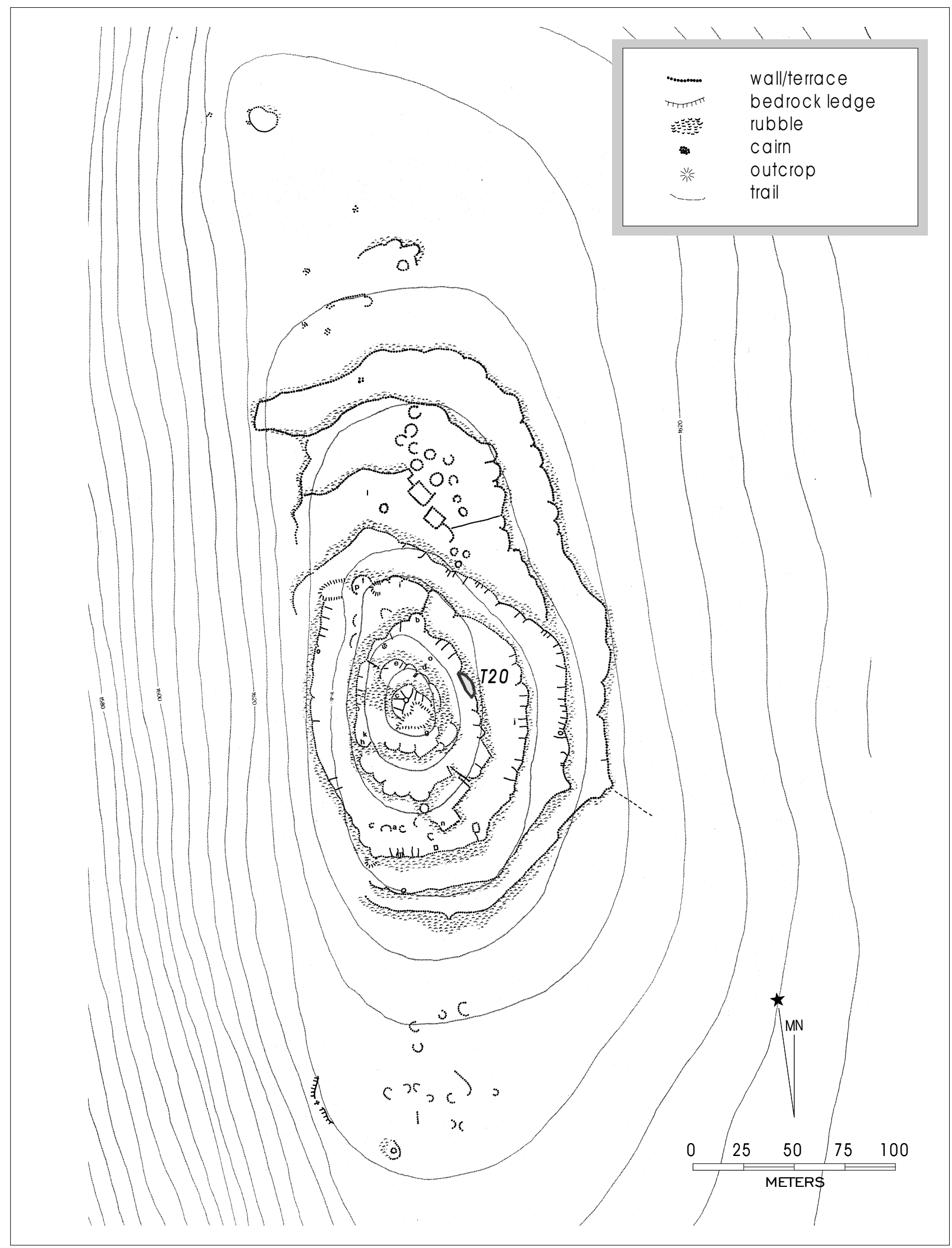

igure 5. Cerro Vidal with 1998 excavation. 
or more in depth. In addition we looked for ashy deposits, bone exposed on the surface, and artifact associations suggesting intensive use. Finally, at Cerro Juanaqueña we attempted to select terraces from various parts of the site, so that we could more confidently define the span of occupation. It is possible that different parts of the site were occupied at different times, and in order to investigate this possibility chronometric dates from different areas are required.

We were successful in recovering fragments of charred maize from both Cerro los Torres and Cerro Vidal. These samples will allow us to begin dating other cerros de trincheras. At Cerro Juanaqueña eight of the ten terraces tested yielded material suitable for AMS radiocarbon dating. Additional lithic artifacts, bone, and/or botanical materials were also recovered during these excavations and provide the basis for ongoing analyses (see below). We did not find any structural remains, post holes, storage pits, hearths, or other similar features in 1998. The profiles exposed in these test units have also given us a better understanding of formation processes on the cerros de trincheras.

Figure 6 is an idealized stratigraphic profile which reflects our current understanding of the terrace deposits. Each individual terrace exhibits its own distinctive characteristics, but all conform to this general pattern. The deepest stratum in Figure 6 is bedrock. Resting on bedrock we sometimes recognize traces of the original soil which was present on the hillslope before construction of the terraces (zone 1). When present, these original surface deposits can be recognized by the presence of calcium carbonate in the sediment and encrusting the rock. Typically the sediments are very dark grayish brown to black, sandy clay loam, containing about 50 percent basalt pebbles and cobbles with a blocky structure. Above bedrock and original soil is the constructed cobble berm which defines the terrace wall (zone 2). This feature is composed of larger cobbles $(5-20 \mathrm{~cm})$ resting against one another, with relatively little soil (25-50 percent) filling the spaces between the rocks. Behind the terrace wall is the construction fill consisting of a brown sandy clay loam and up to about 25 percent pebbles and some cobbles placed behind the berm deposit which forms the terrace platform (zone 3 ). There is usually more soil in this deposit and the rocks are smaller, allowing it to be distinguished confidently from the terrace wall itself. In most cases the deeper portions of these deposits are very soft, becoming increasingly compact toward the surface. We hypothesize that during original construction of the terrace many voids remained between the cobbles, and that subsequently through several different mechanisms soil has made its way down to fill these voids. Above the cobble and soil terrace platform deposit we sometimes find a layer of very dark brown, fine sandy clay loam with some pebbles which is 5 to $20 \mathrm{~cm}$ thick (zone 4). Sometimes distinct horizontal zones of compaction can be recognized in this stratum. We believe that this is a layer of fine sediment which the prehistoric inhabitants of Cerro Juanaqueña placed on the terrace platform to provide an actual use surface. In the experimental terrace which we constructed these sediments worked their way down into the platform itself, filling voids between

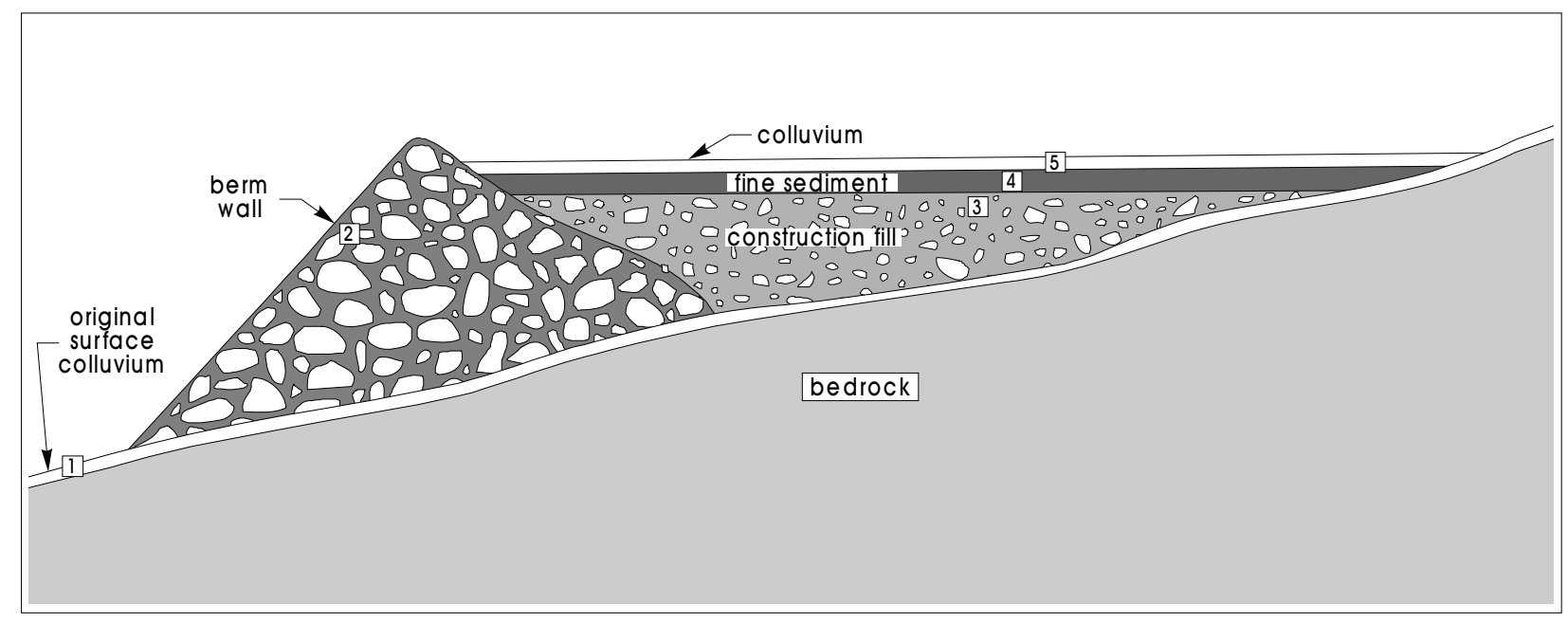

Figure 6. Idealized terrace construction stratigraphy. 
cobbles. If this happened in prehistoric times, it would have been necessary to periodically add new soil to the surface. Above this layer we often find a few centimeters of fine sandy loam which are also dark brown, although slightly lighter in color (zone 5). These appear to be post-occupational deposits, probably derived from material transported to the hill by aeolian processes, then redeposited as colluvium on the terrace surfaces leaving multiple fine laminae.

\section{Backfilling}

A combined total of 44 shovel tests, units, and backhoe trenches were excavated (see Geomorphological Studies and Appendices 1, 2, and 3). With the exception of the backhoe trenches, before initiating these excavations, an area within close proximity of the shovel test or unit was selected for screening of excavated soils. The surface area was then covered with plastic sheeting in order to isolate the screened soils, and subsequently facilitate the backfilling process. The last two days of field work were utilized for this process. Prior to backfilling, a coin and/or aluminum can was placed the test unit, which was then covered over with plastic sheeting. The units were then backfilled with the excavated backdirt. The process was photodocumented and the photographs are on file at the Center for Archaeological Research, University of Texas at San Antonio (CAR-UTSA). Backhoe trenches were all backfilled as well.

\section{Additional Field Studies}

\section{Surface Collections}

During the 1998 field season we continued to collect artifacts from the surface of the three sites. As in past years the location of each artifact was carefully plotted on a large-scale maps of the sites. Each artifact is numbered individually and entered into the curated collection of artifacts and samples. Table 2 summarizes the items which were collected in this way from each of the three sites.
Table 2. 1998 Surface Collections

\begin{tabular}{|l|c|c|c|}
\hline & $\begin{array}{c}\text { Cerro } \\
\text { Juanaqueña }\end{array}$ & $\begin{array}{c}\text { Cerro los } \\
\text { Torres }\end{array}$ & Cerro Vidal \\
\hline Projectile Points & 24 & 7 & \\
\hline Biface & 5 & 1 & \\
\hline Cruciform & 3 & & \\
\hline Drill & 1 & & 1 \\
\hline Notched Flake & 1 & & \\
\hline Utilized Flake & 1 & & \\
\hline Core/Split Cobble & 2 & & \\
\hline Stone Bowl & 5 & 1 & \\
\hline Stone Pipe & 1 & & \\
\hline Mano & 2 & & 1 \\
\hline Metate & 2 & & \\
\hline Pestle(?) & & 1 & \\
\hline Sherd & & & 1 \\
\hline Obsidian Nodule & & & 1 \\
\hline
\end{tabular}

Digital images of all of the projectile points and other small chipped stone artifacts were captured by scanning them directly using a digital scanner (Houk and Moses 1998). Preliminary drawings of many of these artifacts have been made using CorelDraw7, based on the scanned image (Figure 7).

\section{Ground Stone}

The large numbers of manos and metates present on the surface of Cerro Juanaqueña offer an important source of information about the kinds of food processed, the extent of food processing, and the locations of residential activity. During the 1997 field season we conducted a detailed analysis of a surface sample of ground stone tools both from terraces that were tested and with transect sampling units. During the 1998 season we continued to collect surface ground stone data by making detailed observations on all ground stone tools found on the surface of each excavated terrace.

During the surface mapping of each terrace and prior to initiating excavations, the crew placed pin flags by all ground stone tools, as well as other significant artifacts, and marked their location on the map. An identifying number was assigned to each ground stone tool. Later one or two team members would return to the terrace and walk over the surface a second time to 


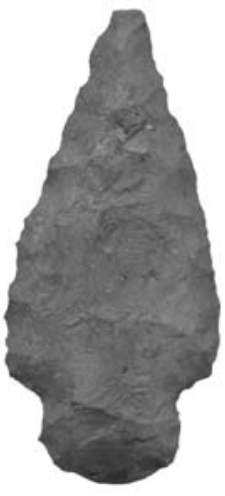

a

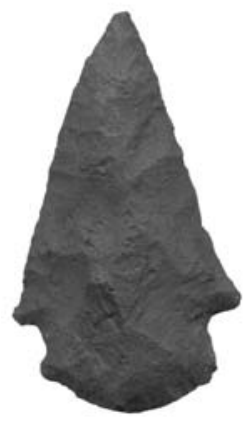

e

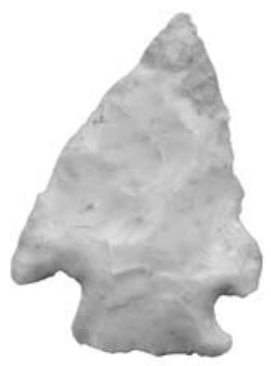

i

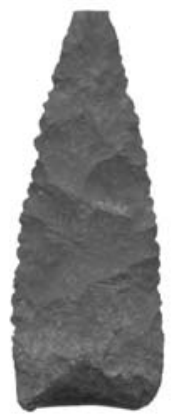

b

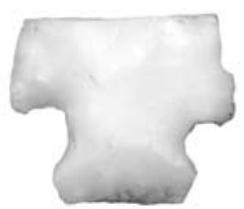

$f$

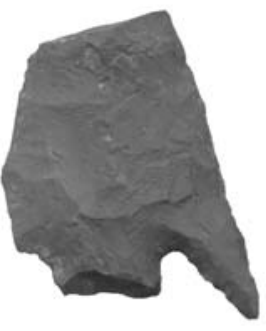

j

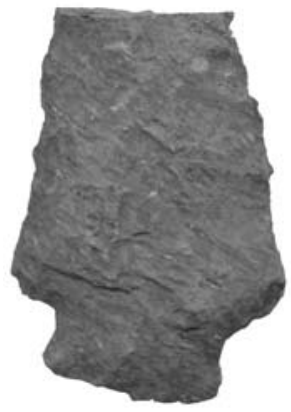

C

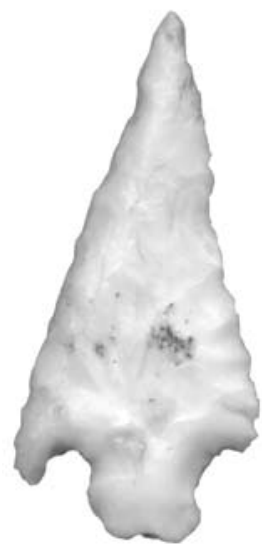

g

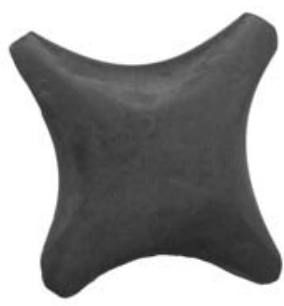

k

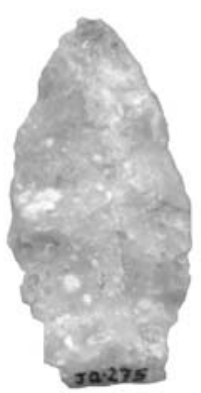

d

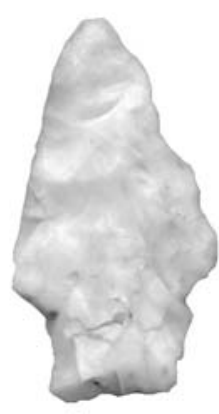

$\mathrm{h}$

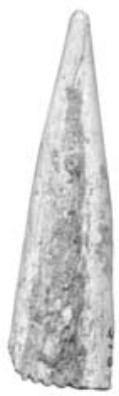

I

Figure 7. Cerro Juanaqueña projectile points. $\mathrm{K}$ and $\mathrm{L}$ are a cruciform and distal end of a bone awl. 
search for additional ground stone tools prior to recording the tools as the dense rocks on the terrace walls made the ground stone tools difficult to see. Each tool or tool fragment would then be closely examined and its attributes recorded. For the manos the following attributes were recorded in the field: feature, item number, material, number of ground surfaces, degree of wear, the presence of edge shaping, the presence of pecking, the presence of striations, striation direction, plan shape, cross-section shape, length, width, thickness, plan shape, and the surface depositional context (on terrace surface, talus slope, etc.). For the metates we recorded the same information as the manos and these additional attributes: metate type; the dimensions of the hole in the bottom of the metate, if present; the length and width of the grinding surface; and the depth of wear. In addition to this recording, we drew and photographed samples of various metate and mano forms and we collected a few of them.

In 1998 we recorded a total of 17 whole manos and seven mano fragments from the surface of nine terraces and one rock ring. Each terrace had between one and five manos present. The combined results of 1997 and 1998 indicate a total of 80 whole manos have been recorded from 32 features. Eighty percent of these were manufactured from the local basalt with the balance being made from rhyolite and unknown materials. There are at least two general groups of manos. One tends to be more circular or oval in plan and convex to spheroid in cross-section. This shape was likely used with the heavily used, large basin metates. The second form is flat in cross-section and was likely to have been used with the small grinding slab metates. The mean area of all manos is $141 \mathrm{~cm}^{2}$ and the mean length is $13 \mathrm{~cm}$, indicating these are small compared to those found in later pueblo sites yet they are somewhat larger than typical Archaic manos. Recent research by Hard and others has suggested that mano size is related to agricultural dependence. The manos at Cerro Juanaqueña are roughly comparable in size to those from a number of pithouse period occupations in the Southwest that exhibit a moderate level of agricultural dependence (Hard et al. 1996). For example they are similar in size to manos used during the Dona Ana phase (ca. A.D. 1100-1200) in the southern Jornada area of southern New Mexico and west Texas and those used during the Basketmaker
II period in the Black Mesa region of northern Arizona.

In 1998 we recorded 65 metate or metate fragments on the surface of eight terraces and one rock ring feature. Metate and metate fragments are more common than manos, with as many as 20 metate pieces occurring on one terrace. Combining the 1997 and 1998 metates and considering only whole metates, 55 whole metates have been recorded on 22 terraces and one rock ring, with as many as seven occurring on a single feature. All of the whole metates were made out of local basalt, although a few rhyolite metate fragments are present. Fifty-five percent of these were basin forms, 44 percent were slab forms and 1 percent were a combination slab and basin. The basin metates are large, with overall dimensions averaging $60 \mathrm{~cm} \times 47$ $\mathrm{cm} \times 17 \mathrm{~cm}$. The deeply worn basins have steeply angled sides that form almost a V-shape with deep wear that averages $8.2 \mathrm{~cm}(\mathrm{n}=30)$ which indicates intensive food grinding activity over many generations. The slab metates are much smaller, averaging $32 \mathrm{~cm}$ x $29 \mathrm{~cm} \times 12 \mathrm{~cm}(\mathrm{n}=24)$, tend to be only lightly worn, and show no signs of resharpening or shaping. Clearly the slab metates were used far less intensively than the basin metates, probably for grinding a different food. It appears that there are at least two types of metate-mano sets. The spheroid to convex manos were apparently were used on the heavily worn, large basin metates while the flat manos were used on the smaller, lightly used slab metates. However, at this time we do not understand the specific functions of each type of set.

\section{Aerial Photography and Mapping}

In 1998 we contracted with Cooper Aerial Photography, SA for low-level aerial photography (nominal scale: 1:8000) at five of the cerro de trincheras sites in the Rio Casas drainage. The five sites were Cerro Juanaqueña, El Canelo, Cerro los Torres, Cerro La Cruz, and Cerro Vidal (see Figure 2). Before the photography we established between five and ten ground control points at each site. The control points were marked on the ground and their vertical and horizontal relationships were measured using a total station or electronic distance measuring (EDM) equipment. 
Livestock and thunderstorms destroyed five of the six control points at Cerro la Cruz before the photography was taken. However, at the other four sites the ground control points are visible in the aerial photographs and development of stereographic models can take place without any further fieldwork. The aerial photography was taken in July 1998.

Cooper Aerial Survey Co. developed an orthophoto and topographic map from the 1:8000 scale aerial photographs of Cerro Juanaqueña. The orthophoto consists of a 1:1000 scale mylar print and blueline paper copies covering an area approximately $900 \mathrm{~m} \mathrm{x}$ $1000 \mathrm{~m}$ in size, centered on Cerro Juanaqueña. We also obtained a digital CD-ROM copy of the orthophoto (100 mm ground resolution, $500 \mathrm{dpi}$ at $1: 1000)$. Many details of the cultural features are visible in these documents. The topographic map also covers an area $900 \mathrm{~m} \times 1000 \mathrm{~m}$ in size. The mylar version of this document was printed at a scale of 1:2000 with one meter contour intervals, while the digital copy includes versions with both one-meter and five-meter contour intervals in AutoCad DWG and ASCII point file formats.

We have produced an accurate base map of the entire site by combining these two data sets (the orthophoto and the topographic map) with the tape-and-compass map prepared by Roney during Minnis and Whalen's 1995-1996 project. The tape-and-compass map was scanned, and the orthophoto and topographic map were imported directly into the computer drafting program CorelDraw7. The scale of these three images was manipulated until all were identical. We then superimposed the tape-and-compass map over the orthophoto and adjusted the locations of the cultural features to correspond to their locations as they appear on the orthophoto. A similar process was then completed using first the topographic map by itself, and then the orthophoto and topographic map used together. The final result is a computer file which consists of high resolution, rectified aerial imagery, topographic contours, and cultural features. These data sets are built on different layers, so we can work with any of the three along or with any combination of orthophotography, topographic map, and map of cultural features. In future years we hope to fine-tune this map through ground-truthing, and to develop comparable information for some of the other sites.

\section{Riverine Geomorphological Investigations}

A significant component of our research has involved exploring the geomorphology of the riverine floodplains below the site in order to answer two questions: First, are there buried Late Archaic villages in the alluvium? Second, was the Rio Casas Grandes aggrading during the Late Archaic period? At the time of its occupation, Cerro Juanaqueña probably would have been part of a land-use system that included numerous sites in diverse ecological settings. Certainly the major drainages would have been intensively utilized. However, the archaeological survey conducted by P. Minnis and M. Whalen (1994) failed to locate a single Archaic site along the Rio Casas Grandes, despite the presence of numerous Viejo and Medio period sites. It is likely however, that Late Archaic sites were buried under riverine alluvium and are no longer visible on the modern surface.

In southern and southeastern Arizona large Late Archaic farming villages formed along the principal drainages that were particularly suitable for farming due to climatic induced changes in stream behavior (Huckell 1996). Prior to 4000 в.P. increased rainfall and warmer temperatures brought about rapid down cutting and erosion of stream channels. By 3000 в.Р. this trend had reversed itself and more modern conditions with reduced rainfall and cooler temperatures prevailed. These conditions resulted in slowly aggrading floodplains. B. Huckell (1996) has proposed that an aggrading floodplain environment was particularly conducive to farming as overbank deposits provided excellent agricultural fields and slightly cooler temperatures would have enhanced the effective moisture available to plants. Were the conditions that were found in southern Arizona also present in northern Chihuahua?

In order to answer these two questions Lee Nordt, assistant professor of geology at Baylor University, examined the floodplains below Cerro Juanaqueña to search for buried Late Archaic sites and to reconstruct the alluvial history of the both the Rio Casas Grandes 
and Rio San Pedro as they converge only one km northwest of Cerro Juanaqueña. Aerial photographs, maps, and field observations were used to construct a geomorphic map and valley cross-sections. A total of 18 backhoe trenches were excavated in 1997, and in 1998 16 new trenches were opened and seven of the previous years' trenches were reopened to examine the alluvial stratigraphy. All trench locations were first approved by either the land owner or ejido president, as appropriate. The backhoe trenches were also fenced to prevent harm to livestock. The modern surface of each trench location was carefully inspected to avoid any surface archaeological remains.
Nordt made detailed stratigraphic descriptions of most of these trenches and collected soil samples for humate $\mathrm{C}_{14}$ dating. Sediment to be used for pollen analysis was also extracted from these humate samples for paleoenvironmental data. The discussion below incorporates the analysis of the 1997 investigations (Nordt 1998) and preliminary findings from the 1998 data as well as 16 radiocarbon dates. Six landforms were identified: the Holocene floodplain alluvium, the Holocene flood terrace alluvium (Jorge terrace), the Late Pleistocene flood terrace alluvium (Oaxaca terrace), a Pleistocene alluvial fan, a bedrock/fan alluvial complex, and bedrock (Figure 8).

The bedrock/fan alluvial complex emanates from a valley north of the town of Janos and is Pleistocene in age. The

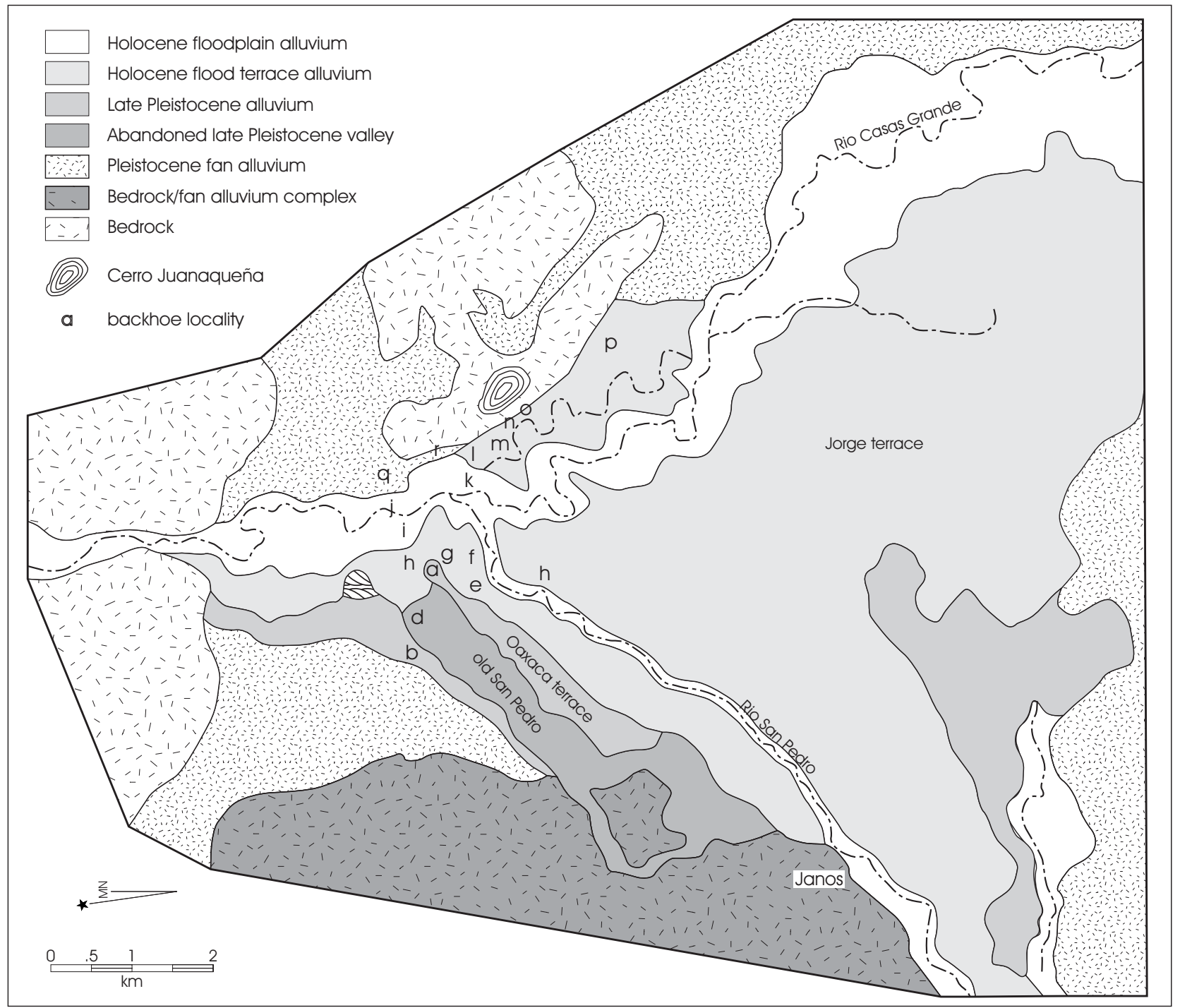

Figure 8. Geomorphic map of the Rio Casas Grandes and Rio San Pedro. 
distal end of this fan is present on the west side of the Rio Casas Grandes valley. The second fan is also Pleistocene in age, although portions have a Holocene alluvial veneer. This alluvial fan is present to the east and west of the Rio Casas Grandes valley (see Figure 8).

Three alluvial landforms have been identified. The Late Pleistocene alluvial terrace is the highest and oldest landform of the Rio Casas Grandes and Rio San Pedro and has been named the "Oaxaca terrace" and is present on both sides of the Old Rio San Pedro. The Holocene flood terrace is known as the "Jorge terrace" and it is below the Oaxaca terrace on the west side of the Rio San Pedro as well as on the west and east sides of the Rio Casas Grandes. The Holocene floodplain is the modern alluvial floodplain of the Rio Casas Grandes and it is below the Jorge terrace.

Five paleosols have been identified buried under the Jorge terrace and within the Old San Pedro Valley as well as a buried peat layer. Paleosols form during periods of stability when flooding events are infrequent enough to allow the surface to become vegetated and an A soil horizon to form. As such they are one of the best contexts to locate buried archaeological sites. The deposits, from oldest to youngest are: the peat layer, the Antonio paleosol, the Pedro paleosol, the Trincheras paleosol, the Janos paleosol, and the Viejo paleosol. Table 3 lists the radiocarbon dates for each deposit and Figures 9 and 10 show the cross-sections.

A peat layer, dating to ca. 9000 radiocarbon years B.P. was identified in the Old San Pedro valley about 2.3 $\mathrm{m}$ below the modern surface. Peat is a deposit of plant remains which contains little mineral matter. It forms under constantly water-saturated conditions and the plant remains may not be fully decomposed (Waters 1992:31). Shortly after 9000 B.P. the Rio San Pedro migrated to the northeast about one $\mathrm{km}$ from the Old San Pedro valley to its modern location.

The Antonio paleosol was identified in the Old San Pedro Valley about $150 \mathrm{~cm}$ below the surface and dates to about 4500 radiocarbon years B.P. The Pedro paleosol was located west of the modern Rio San Pedro channel, about $3.3 \mathrm{~m}$ below the Jorge terrace and it dates to approximately 3600 в.P.
The Trincheras paleosol is the most significant with respect to this project as it is dated to approximately 3100 radiocarbon years $\mathrm{B}$. P. based on two humate radiocarbon dates. This paleosol lies about $2 \mathrm{~m}$ below the modern surface of the Jorge terrace and probably would have been the surface that was exposed during the occupation of Cerro Juanaqueña. Attempts to locate buried archaeological sites in this paleosol have thus far been unsuccessful although the remains of a single, disturbed hearth, represented by $2-3$ scattered burned rock fragments and a few small $(1 \mathrm{~cm})$ pieces of charcoal. Unfortunately the charcoal contained too little carbon to successfully date.

The Janos paleosol dates to approximately 2000 в.P., based on five radiocarbon dates. It is typically found between about $75-125 \mathrm{~cm}$ beneath the modern surface and was identified within the Jorge terrace and somewhat deeper in the Old San Pedro Valley. The Viejo paleosol is found between about $170-265 \mathrm{~cm}$ below the modern Rio Casas Grandes floodplain and it dates to approximately 1600 to 1500 в.P., based on two radiocarbon dates. This sequence of six datable deposits lying beneath the floodplain offers significant possibilities of locating buried archaeological sites contemporaneous with Cerro Juanaqueña as well as to reconstruct the changing form of the river as we continue our analysis and field work.

\section{Trincheras Geomorphological Investigations}

Lee Nordt also conducted geoarchaeological investigation of the constructed terrace features on Cerro Juanaqueña for the purposes of better understanding the terrace formation processes including the identification of natural, anthropogenic, colluvial, and alluvial deposits. It was also hoped that his investigations would help us identify occupational surfaces and evaluate the possibility that floodplain deposits were transported from the Rio Casas Grandes up to Cerro Juanaqueña to use for construction. In 1997 and 1998 he made detailed stratigraphic descriptions of the terrace profiles of the terraces and collected samples for micromorphological thin sections and bulk soil analyses. In 1997 Nordt described T6 and T167 and in 1998 he described T10, T126, T163, R234a, T297, and T387. For comparative purposes he also made test 


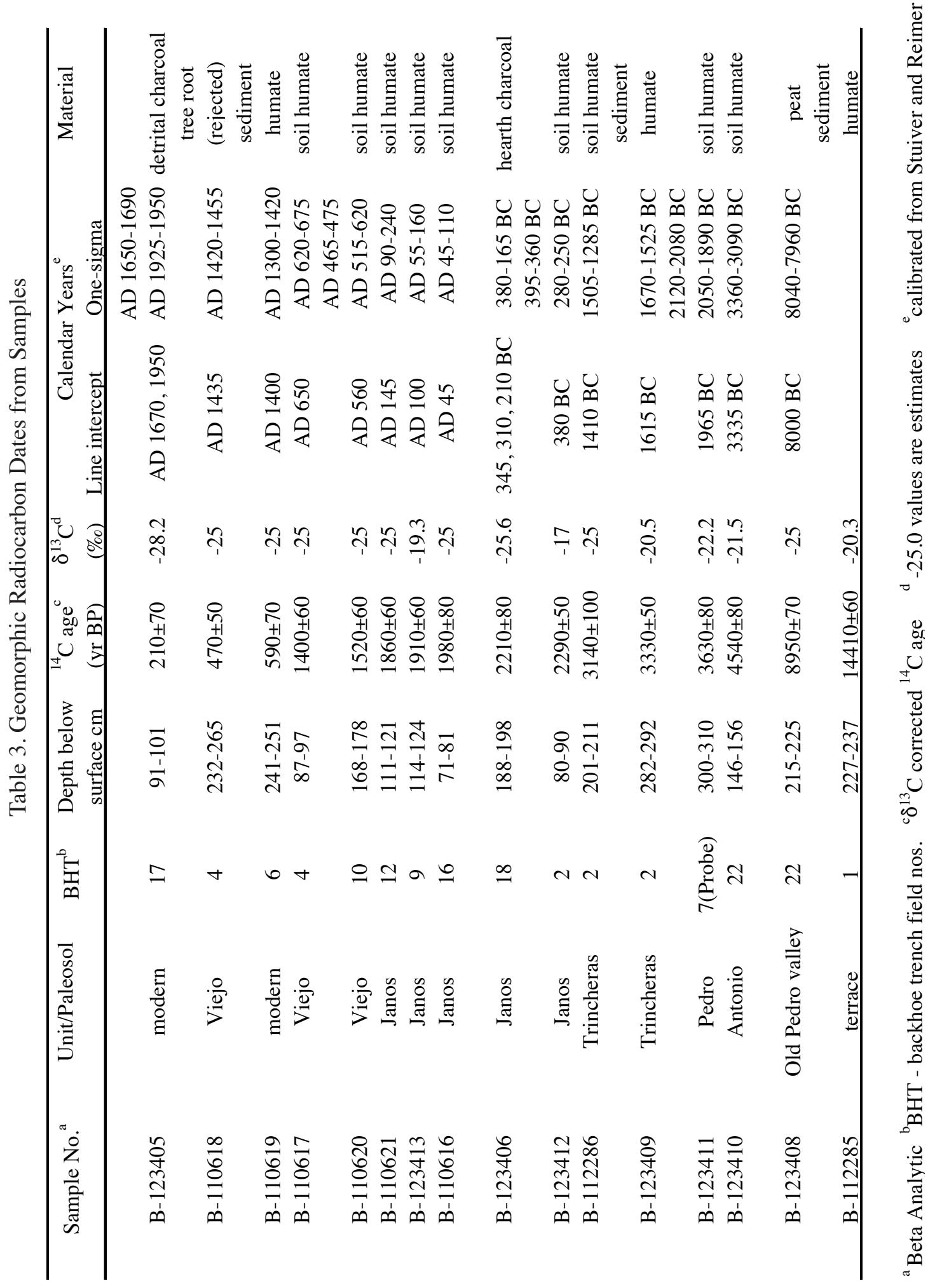




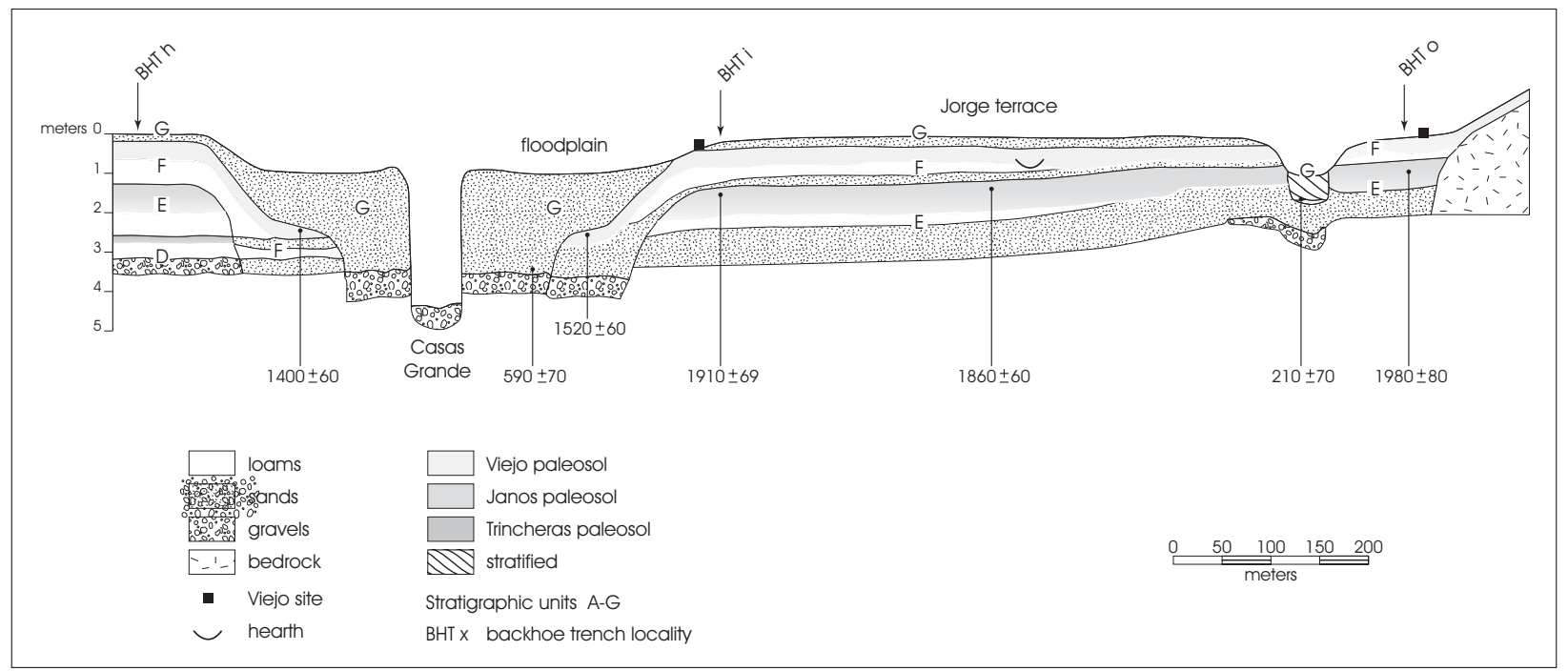

Figure 9. Geomorphic cross-section of the Rio Casas Grande.

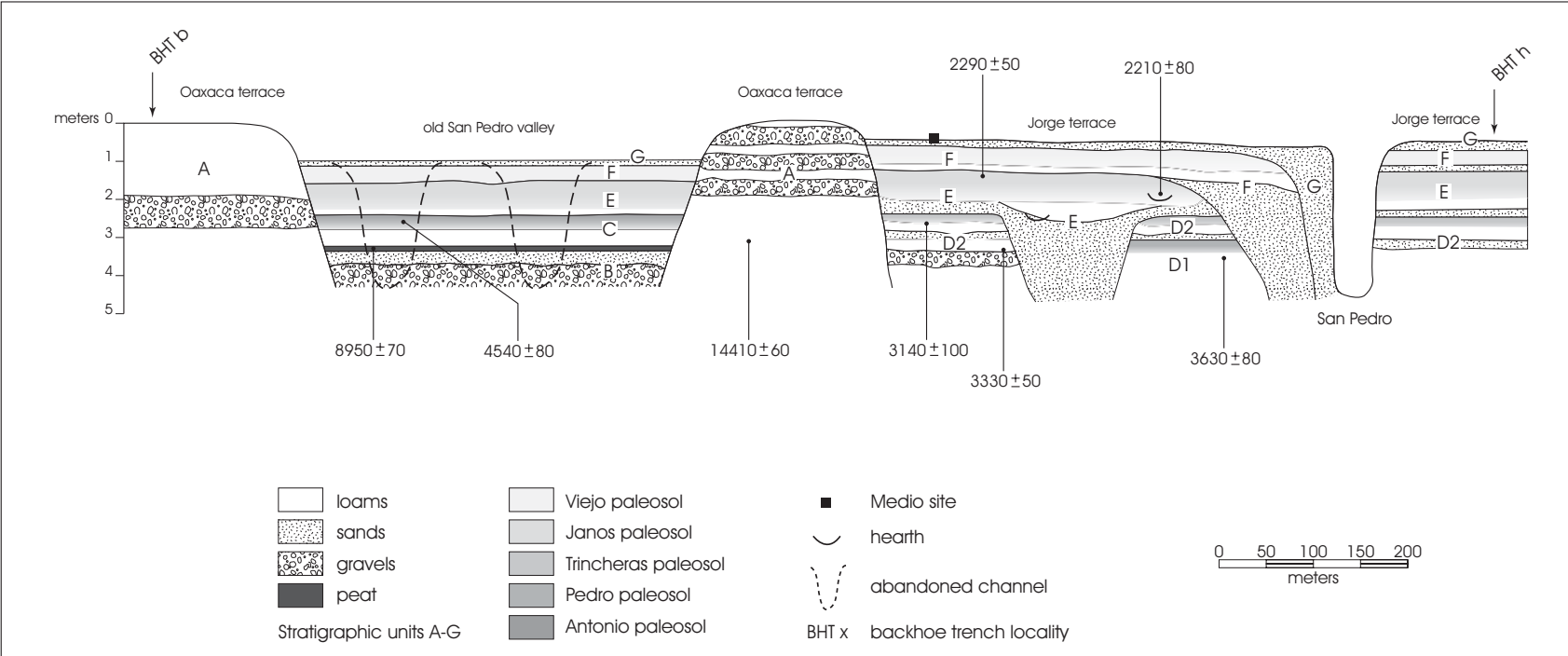

Figure 10. Geomorphic cross-section of the Rio San Pedro.

excavations and stratigraphic descriptions of three shovel test units into the natural hillslope of the hill immediately south of Cerro Juanaqueña. Thin section samples have been submitted for T6, T167, and T163 as well as the shovel tests. In addition bulk soil analyses that will yield particle size distribution, calcium carbonate content, and organic carbon samples have been submitted for T163, T387, and the shovel tests. Preliminary results of the T6, and T167 geomorphological work were presented in our previous informe for the 1997 work.
Thus far Nordt's analyses confirm the general schematic formation sequence described earlier in the "Test Unit" section. The micromorphological analysis found chert and quartz grains in the Cerro Juanaqueña terraces that are not indigenous to the hill. There are three possibilities that could explain their existence on the hill: 1) transported by aeolian processes from the floodplain; 2) a product of stone tool manufacture; 3 ) sediments may have been transported from the floodplain up to the hill by the inhabitants to use in construction. Although we cannot be certain, the first alternative is considered the most plausible at this time as the grains are rounded which is consistent with aeolian or fluvial contexts. 


\section{Terrace Labor Costs and Function}

The 486 terraces and 108 rock rings constructed at Cerro Juanaqueña are striking and continue to challenge many existing notions concerning the Late Archaic period. Such questions as community size, regional population levels, level of sedentism, role of agriculture, social and political organization, level of intergroup conflict, and scale of land modification are now being reconsidered. One approach to understanding some of these issues is through the consideration of the labor needed to construct this site.

Native Americans constructed the terraces by first piling the local basalt cobbles to form berms that bowed out in the center and pinched in at the ends against the slope. The pocket between the apex of the terrace and the slope behind was then filled in with smaller rocks and finally sediment to form almost level surfaces that average about 50 square meters in size. Many of the terraces form small groups when 2-5 terraces connect end-to-end. In one case about 25 joined terraces form a 400 meter long alignment along the northern, eastern, and southern site perimeter.

The scale of the site clearly indicates that it was not constructed by the social unit expected for the period, a small foraging band. In fact, sites of this scale have been attributed to large agricultural societies with varying levels of sociopolitical complexity. In order to better understand the labor and organization needed to construct a terrace we built one during our first field season in 1997. During 1998 we had additional maps and aerial photos made of the site and we have recently conducted further analysis of these data.

In 1997 we selected a hillside near Cerro Juanaqueña that also had a 20 percent slope, dense basalt cobbles and thin soil to construct a terrace. A team consisting of two local men and a member of our team, José Zapata, constructed a terrace that was similar to the prehistoric ones. Sr. Zapata kept a detailed record of the labor and materials used so we were able to estimate the total cost of constructing a terrace. They built the terrace in 65 person hours using about 30 cubic meters of rock and about 4 cubic meters of dirt. Using detailed maps, cross-sections, and computer analysis of the terraces at Cerro Juanaqueña we were able to estimate that the total volume of rock and dirt used to build all of the terraces is about 31,500 cubic meters or about 58,000 metric tons. We estimate that the site represents about 30 person-years of labor, if modern 40-hour work schedules were used.

These energetic estimates indicate that our workers moved an average of 1 cubic meter of rock and dirt every 1.9 person hours. This is 9-14 times faster than other archaeological building experiments and much faster than archaeologists can dig! The reason these terraces can be built relatively rapidly is that rocks were simply picked up, tossed, or sometimes rolled only a few feet before being dropped into place. Unlike most traditional building projects, the terrace construction involves only slight transport costs and their assembly consists of no more than dropping or tossing the rocks into place (Hard et al. 1999).

We can put this labor investment into perspective through comparisons of labor costs for pithouse and pueblo architecture. This level of work appears to be roughly equivalent to about 135 large Anasazi-style pithouses ( $5 \mathrm{~m} \times 5 \mathrm{~m} \times 1.5 \mathrm{~m}$ deep) with support posts and roof or a 600 room pueblo consisting of 200 living rooms and 400 storage rooms. Sites of this magnitude were generally not constructed in Northwest Mexico or the American Southwest until late in the first millennium A.D., 1500-2000 years after Cerro Juanaqueña was constructed.

Were the Cerro Juanaqueña terraces built for farming? We evaluated the labor costs and potential productivity of farming these terraces to answer this question. The total flat surface area behind the terraces is estimated to be approximately 2.5 ha. Therefore it would have taken an astounding 4300 days to construct each hectare of planting surface. In contrast, prehispanic agricultural terraces in the Maya region and modern Mexican terraces are estimated to have construction costs of approximately 50-850 person days per hectare and the specialized Maya raised fields cost between 950-3000 person days per ha. to construct. Thus if Cerro Juanaqueña terraces were constructed for farming, their labor cost was more than five times the cost per ha expended by the Maya in their agricultural terraces and roughly similar to their extremely labor intensive raised fields. Such high ag- 
ricultural labor costs are only usually invested when there are very large populations, such as those found in complex civilizations. There is nothing to suggest Late Archaic populations even approached this level of occupational intensity or engaged in such intensive agricultural practices. If the total of 2.5 ha of flat surface found behind all 486 terraces was planted in maize the harvest would only support about 4 adults for a year, assuming each adult could be supported on approximately .6 ha per year, the farming land area each Tarahumara Indian needs today (Hard et al. 1999).

It has been suggested that some cerros de trincheras in Arizona were built as garden plots to take advantage of the longer growing seasons that exist on the hilltops and upper slopes above the cold air inversions of the drainages. However, the virtual absence of winter rain in the Chihuahuan Desert would make winter farming an unlikely purpose of the terraces. Also no water control features are found on the terraces. It appears that constructing these terraces for farming would have been impractical at best. Certainly farming would have been far more successful in the wide Rio Casas Grandes floodplain below the site.

It appears that the Cerro Juanaqueña terraces were constructed as house platforms. The terrace surfaces and excavations reveal ample evidence of household debris including heavily worn, massive basin metates, manos, projectile points, chipped stone debris, ashy sediments, charcoal, charred maize, dense burned and unburned bone, significant quantities of flakes, and other stone artifacts. While no houses have been defined, in 1997 we exposed two small postholes and compact occupational surface in Terrace 6 and in 1998 we defined an additional clearly defined occupational surface in Terrace 163. However, a domestic function for these platforms would not preclude families maintaining small household gardens as part of the residential function.

We have not yet identified any public architecture at Cerro Juanaqueña although public architecture among semisedentary and early sedentary societies is quite common. Certainly there are no mounds, constructed public platforms, or above-ground ceremonial walled buildings representing large-scale communal architec- ture such as those associated with the Paquime, Hohokam, or Trincheras culture sites. Even if we do eventually identify communal architectural features it is unlikely that they will have been constructed at significantly higher levels of labor effort than the domestic terraces. Based on ethnographic analogy and given the relative ease that a terrace can be constructed we would expect that the people who occupied Cerro Juanaqueña were largely egalitarian. Each family probably constructed their own terrace platforms rather than specialized builders.

While family labor groups probably built the terraces, the location of at least some of the terraces was planned. The most obvious of these is the encircling chain of 25 joined terraces that form a site perimeter on three sides. The construction efforts of many different families would probably have been coordinated to achieve this. This suggests that one or more individuals were responsible for site planning and determining where some terraces were to be built. By applying what we know of ethnographic situations, we can suggest this leader may have had only limited authority.

The evidence suggests the terraces were not constructed as agricultural features but were constructed as house platforms. Why would Native Americans have expended the labor to live on a hilltop? Not only are the construction costs substantial, but the daily energy costs of transporting water, wood, and food up to the hilltop village would not have been insignificant. Certainly there are plenty of locations near the river that were occupied in later centuries. The longest-standing explanation for the function of cerro de trincheras, defense, is the explanation we are now considering. Under this scenario people were motivated to construct house platforms on the hilltop because raids from competing groups were common. The terraces did not serve as defensive fortifications, but by merely aggregating on the hilltop the occupants maintained an effective defensive posture. The steep hillslopes would be difficult to attack, particularly if the only weapons were thrusting spears or spears used with throwers or atlatls. Given the nature of warfare in egalitarian or nonhierarchical societies, such a defense would likely be successful, particularly since sieges, which cut-off supplies to defenders, were not 
conducted by egalitarian societies as the attackers would not have the logistical support sieges require (Keely 1996). Strike and run was the preferred method of war.

However, accumulating direct archaeological evidence in support of the defense hypothesis is difficult. We do not yet have any riverine sites to compare with the hilltop site nor to do we have such direct indicators as burials with evidence of injuries. At the current time we can speculate that these terraces were constructed as part of a defensive strategy while we continue to gather data and examine the issue.

\section{Rock Art}

Some additional photographs were taken to provide more detailed documentation of rock art at Cerro Juanaqueña, Cerro los Torres, and Cerro Vidal. Locations of the rock art panels at Cerro Juanaqueña are indicated on Figure 11.

\section{Collection of Modern Plants}

One of our principal research objectives is to learn more about relationships between the prehistoric inhabitants of Cerro Juanaqueña and their natural environment. An important first step in realizing this goal is documentation of modern vegetation in the vicinity of the site. In September, 1998 ethnobotanist Dr. Karen Adams made an inventory of plants growing in the Janos area, including collection of 63 botanical specimens. The inventory focused on Cerro Juanaqueña and the adjacent floodplain, river terraces, and modern agricultural fields. Other plants were documented at Ojo la Palatoada, a wetland located a few kilometers west of Janos. Altogether we documented 100 taxa from 37 different families. The specific plants are listed in Appendix 4.

\section{Temperature}

One of the proposed uses of the terraces was as agricultural terraces that were designed to take advantage of warmer temperatures and an extended growing season that may exist on hillsides above the cold air drainage. In fact, temperature data from Tucson indicates that the slopes and top of Tumamoc Hill have a five month longer growing season than the river valley below (Fish et al. 1984). In order to evaluate this possibility we placed a transect of eight digital, batteryoperated thermal cells in a transect from the Jorge terrace of the Rio Casas Grandes up the west side of Cerro Juanaqueña to the peak of the hill and partially down the east side of the hill. These battery-operated thermometers were set to take a temperature reading every six hours for one year. When we return in the summer of 1999 we will download the digital data from the thermal cells into a laptop computer so we may then examine the temperature differences, particularly through the winter months, between the river valley and hillslope.

\section{Analytical Results}

\section{Radiocarbon Dating}

One of the principal objectives of our 1998 excavations was recovery of additional material for AMS radiocarbon dating, and this was a principal concern in selecting terraces for testing. We attempted to select terraces from different areas of the site, and because charcoal is better preserved in deeper terrace deposits, we attempted to select terraces with a meter or more of depth. Of the 10 terraces tested at Cerro Juanaqueña in 1998, eight yielded material suitable for radiocarbon dating. At both Cerro Vidal and Cerro los Torres we were also successful in obtaining fragments of carbonized maize which yielded radiocarbon dates that are reported in Table 4 .

Table 4 summarizes all of the dating results from 1997, and lists those samples which have been submitted from our 1998 season. All of the dated samples from 1997 as well as six samples from 1998 (T10, T97, T126, T167, T290, T297) come from terraces built 


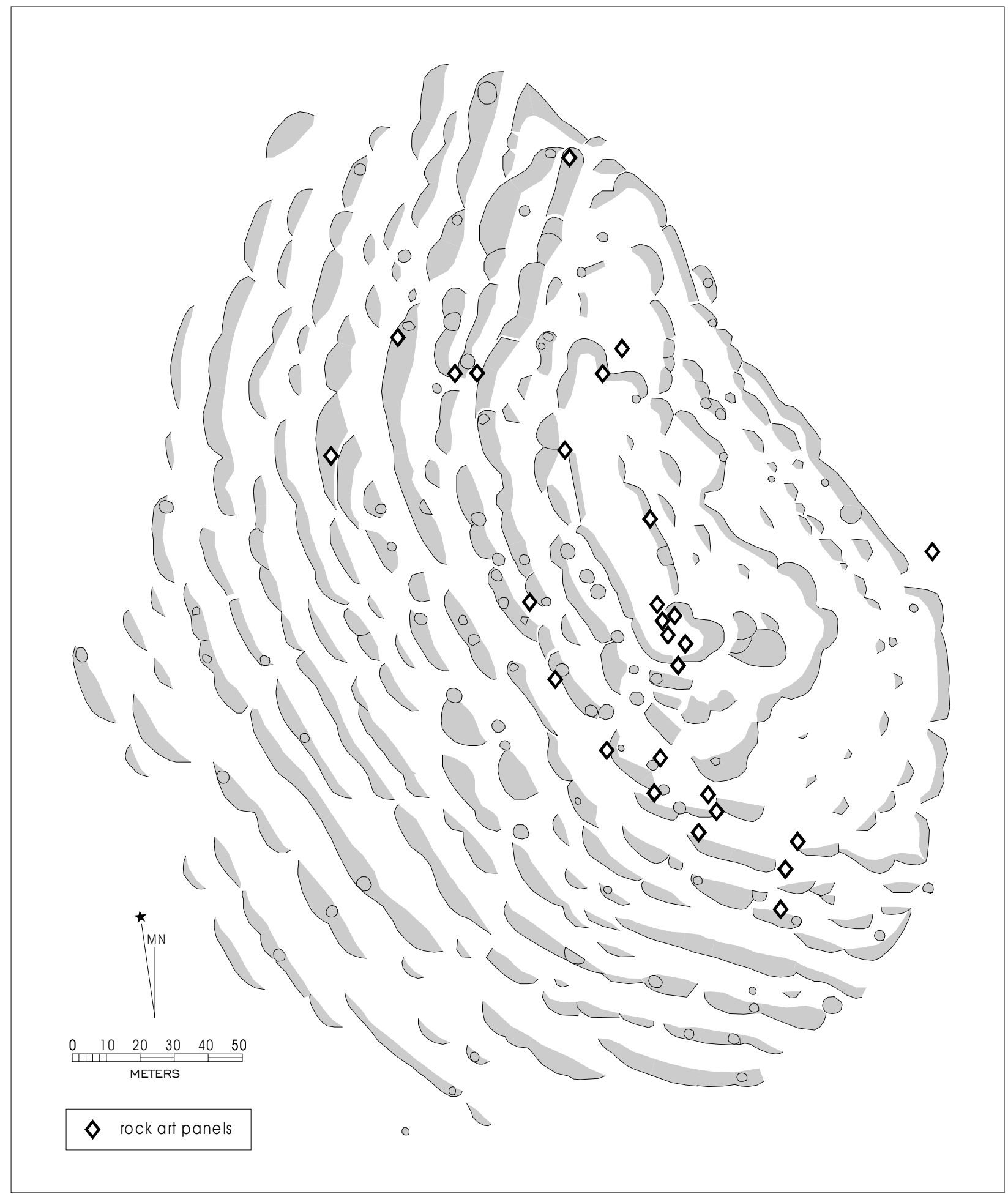

Figure 11. Locational of rock art panels on Cerro Juanaqueña.

on the summit and upper slopes of Cerro Juanaqueña. Two samples (T387, T413) are from terraces near the base of the hill. The samples from Cerro Vidal and
Cerro los Torres were both excavated from terraces on the upper slopes of these two sites. 
Table 4. Summary of AMS Radiocarbon Dating, 1997 and 1998

\begin{tabular}{|c|c|c|c|c|}
\hline Provenience & Material & $\begin{array}{l}\text { INSTARR Lab } \\
\text { No. }\end{array}$ & $\begin{array}{c}\text { Radiocarbon years } \\
\text { BP }\end{array}$ & $\begin{array}{c}\text { Dendrocalibrated } 2 \sigma \text { age } \\
\text { ranges } \mathrm{AD}\end{array}$ \\
\hline \multicolumn{5}{|c|}{ Cerro Juanaqueña (1997) } \\
\hline T537 & Maize cob & 3986 & $2890 \pm 50$ & $910(1030) 1250$ \\
\hline $\mathrm{T} 222$ & 17 Maize cupules & 3995 & $2930 \pm 50$ & $940(1120) 1270$ \\
\hline T6 & Fouquieria splendens & 10056 & $2980 \pm 70$ & $1020(1200,1250) 1380$ \\
\hline T167 & Maize cob & 3983 & $2980 \pm 50$ & $1020(1200,1250) 1380$ \\
\hline $\mathrm{T} 222$ & Cucurbita & 10039 & $2980 \pm 40$ & $1020(1200,1250) 1380$ \\
\hline $\mathrm{T} 222$ & Cucurbita & 3985 & $3310 \pm 60$ & $1430(1530,1570,1600)$ \\
\hline \multicolumn{5}{|c|}{ Cerro Juanaqueña (1998) } \\
\hline $\mathrm{T} 10$ & Maize cupule & \multicolumn{3}{|c|}{ In progress } \\
\hline T97 & 2 Maize cupules & \multicolumn{3}{|c|}{$"$} \\
\hline $\mathrm{T} 126$ & Maize cupule & \multicolumn{3}{|c|}{. } \\
\hline $\mathrm{T} 163$ & Maize cupule & \multicolumn{3}{|c|}{ " } \\
\hline T290 & 2 Maize cupules & \multicolumn{3}{|c|}{$"$} \\
\hline T297 & 2 Maize cupules & \multicolumn{3}{|c|}{$"$} \\
\hline T387 & Maize cupule & \multicolumn{3}{|c|}{$"$} \\
\hline T413 & Maize grain & \multicolumn{3}{|c|}{$"$} \\
\hline \multicolumn{5}{|c|}{ Cerro los Torres (1998) } \\
\hline $\mathrm{T} 1$ & Maize cupule & 10591 & $2920 \pm 55$ & $\mathrm{BC} 200(100) 0 \mathrm{AD}$ \\
\hline \multicolumn{5}{|c|}{ Cerro Vidal (1998) } \\
\hline $\mathrm{T} 20$ & Maize cupule & 10592 & $2100 \pm 40$ & $1265(1120) 930$ \\
\hline
\end{tabular}

\section{Chipped Stone}

Approximately 3200 pieces of debitage, 20 cores, and 38 retouched tools were analyzed from the 1997 and 1998 test excavations at Cerro Juanaqueña during the 1998 season at the field lab by Dr. Brad Vierra of Los Alamos National Laboratory. This analysis included all of the chipped stone from 11 of the 17 features that have been tested thus far. In addition, all of the chipped stone artifacts recovered from the 1998 test excavations at Cerro Vidal and Los Torres were also analyzed. This material consists of about 240 pieces of debitage, two cores and two retouched tools from Cerro Vidal and 280 pieces of debitage, three cores, and three retouched tools from Los Torres.

Several lithic raw material types are represented by the chipped-stone artifacts at Cerro Juanaqueña. The majority of the debitage is made of local rhyolite, with some chert, chalcedony, and obsidian. In contrast, most of the retouched tools were manufactured of chert and chalcedony with less rhyolite and obsidian. Overall, it appears that higher quality materials were gener- ally selected for tool production and lower quality materials for core reduction, with obsidian being rare. The presence of waterworn cortex on all but the obsidian indicates that these materials were obtained from secondary river gravel sources. In contrast, obsidian appears to have primarily been obtained from primary sources since it exhibits nodular cortex without any waterworn rounding.

An in-field analysis was conducted of the gravels in the Rio Casas Grandes to determine if the material types represented in the Cerro Juanaqueña sample were similar to those available in these gravels. It appears that rhyolite also dominates the local river gravels. In addition, there are small amounts of chalcedony and basalt, but no chert was observed. Chert may therefore have been obtained from a more distant source. An x-ray flourescence analysis of 42 obsidian artifacts revealed that they were obtained from several sources (see below). Most of these items were identified as being derived from an unkown source, with less from Lago Fredico, Antelope Wells, Sierra Fresnal and Los Jagueyes. With the exception of the Antelope Wells source in southwestern New Mexico, and 
the undetermined source, the remainder are from adjacent areas of Chihuahua.

The stone-tool technology at Cerro Juanaqueña appears to emphasize core reduction activities. This mostly consists of core flakes with few biface thinning flakes. Only 20 cores were present in the sample. They were reduced using both a split cobble and cobble uniface technique. It appears that local river cobbles were brought on to the site, and then fully reduced into small cores. Many of these are single platform or core fragments.

Thirty-eight retouched tools were analyzed in the sample. They mostly consist of bifaces (11), retouched flakes (7), projectile points (6) and unifaces (6) with fewer notches, denticulates, an endscraper and a possible cruciform. The bifaces and and projectile points exhibit evidence of breakage during manufacturing, with some of the points also having been broken during use. The projectile points exhibit a range in morphology including side-notched, stemmed, and corner-notched forms. Two of the points have beveled edges. The unifaces have steep retouched edges and tend to be manufactured on large thick flake blanks.

In summary, the chipped-stone technology at Cerro Juanaqueña emphasizes the core reduction of local rhyolites that were presumably used as expedient flake tools. There is only limited evidence for the production of retouched tools from local chert, chalcedony, and nonlocal obsidians.

\section{Obsidian Sourcing}

Although most of the chipped stone on Cerro Juanaqueña is material which is available in the immediate vicinity, small amounts of obsidian and chert seem to be non-local stone. We do not yet know where the chert may have originated, but some progress has been made in identification of the obsidian from Cerro Juanaqueña. Figure 12 shows the location of known obsidian sources in northwestern Chihuahua. We submitted 42 samples of obsidian from Cerro Juanaqueña, three samples from Cerro los Torres, and three samples from Cerro Vidal to Dr. Steve Shackley, (Archaeological XRF Laboratory, Phoebe Hearst Museum of

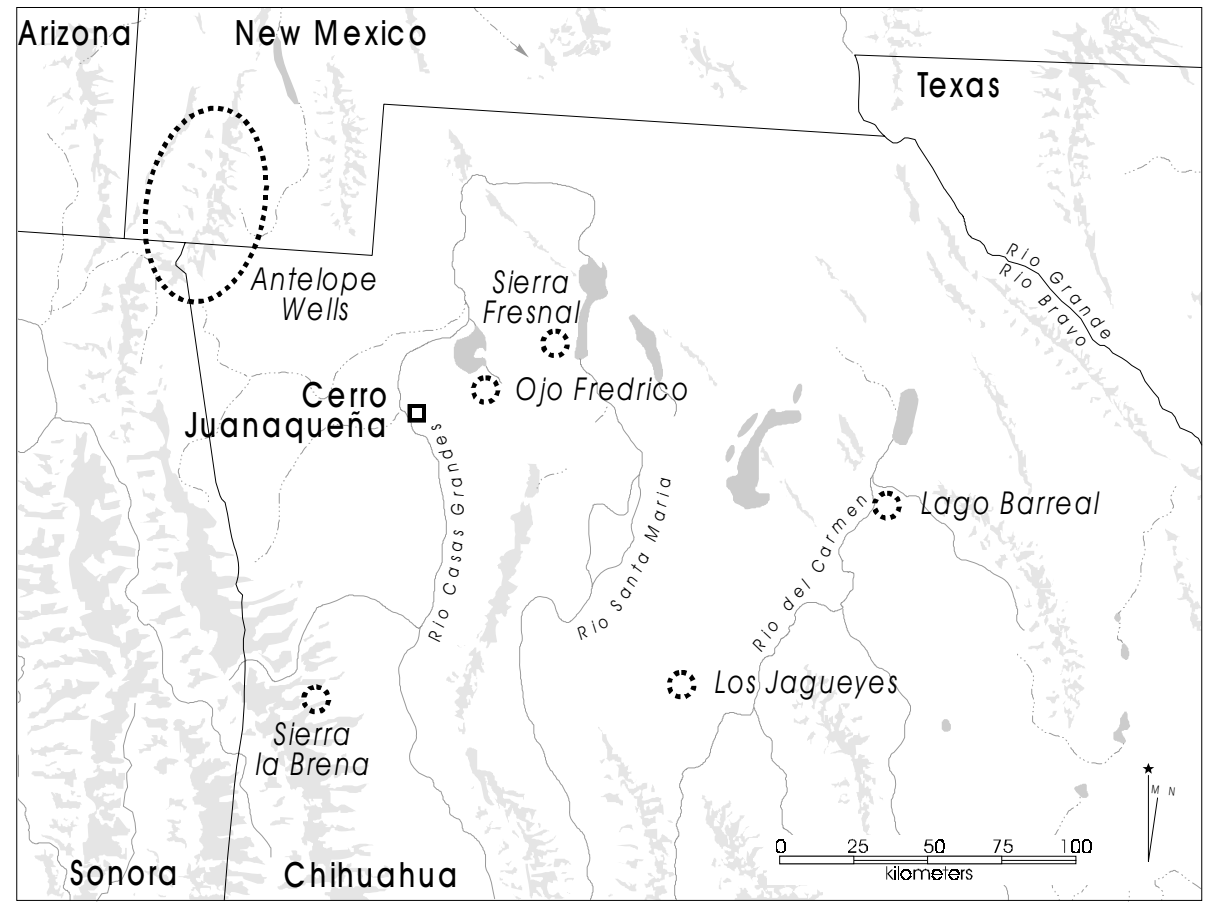

Figure 12. Obsidian sources. 
Anthropology, University of California, Berkeley) for source analysis.

Shackley (1998) used an x-ray fluorescence spectrometer to quantify 10 trace elements in each sample ( $\mathrm{Ti}$, $\mathrm{Mn}, \mathrm{Fe}, \mathrm{Zn}, \mathrm{Th}, \mathrm{Rb}, \mathrm{Sr}, \mathrm{Y}, \mathrm{Zr}$ and $\mathrm{Nb}$ ). The results were statistically compared to trace element composition from known obsidian sources using the computer program SPSS for Windows.

Of the 42 samples from Cerro Juanaqueña, 21 (50 percent) are from a single unidentified source. The high frequency of obsidian from this source may imply that it is located nearby. Eight samples (19 percent) match obsidian source samples from Lago Fredrico, a poorly documented secondary source of obsidian located about $12 \mathrm{~km}$ east of Ascensión. Six of the Cerro Juanaqueña samples (14 percent) match the Sierra Fresnal source. Shackley believes that this obsidian originates in a series of coalesced volcanic domes at the north end of the Sierra Fresnal, but that it has been widely distributed toward the north and east by erosion. Four Cerro Juanaqueña obsidian samples ( 9 percent) come from the Antelope Wells source. Although the primary source of this obsidian is located $90 \mathrm{~km}$ northwest of Janos, this obsidian has also been widely distributed by erosion and undoubtedly occurs closer to the site in alluvium. The remaining three samples from Cerro Juanaqueña match source obsidian from Los Jagüeyes, a secondary source located along the Rio Santa Maria approximately 10 $\mathrm{km}$ northwest of Progresso. The primary source and distribution of Los Jagüeyes are unknown.

The three obsidian samples from Cerro los Torres included two from Antelope Wells and one from Lago Fredrico. The three samples from Cerro Vidal included two from Antelope Wells and one from an unknown source closely resembling that which was well represented at Cerro Juanaqueña.

\section{Faunal Remains}

Archaeological excavations at Cerro Juanaqueña in the summers of 1997 and 1998 produced a large collection of unmodified faunal remains and several modified fragments of bone. An extensive study of the faunal material recovered was undertaken in order to assess the composition of the assemblage and its potential for future research. The study is significant as it represents one of the first quantifiable studies of faunal data from the Late Archaic period in northern Mexico, as well as one of the first reports from a cerros de trincheras site.

A total of 9,885 bones were recovered during the 1997 excavations. Table 5 shows the total number of bones analyzed from both excavation and flotation procedures, the number of identified specimens (NISP) for each site, the number of different taxa identified, the number of burned bones, and the percentage of the assemblage that showed signs of burning.

The majority of the fauna identified consists of jackrabbit (Lepus spp.), cottontail rabbit (Sylvilagus spp.), and indeterminate leporids (see Table 6). Additionally, a small percent of the sample is artiodactyl, including pronghorn (Antilocapra americana), mule deer (Odocoileus hemionus), indeterminate deer, and indeterminate artiodactyl remains. The remaining

Table 5. Summary of 1997 Faunal Analysis

\begin{tabular}{|l|c|c|c|c|c|}
\hline Sample Type & No. Total Bones & NISP & $\begin{array}{c}\text { No. of } \\
\text { Taxa }\end{array}$ & No. burned & $\begin{array}{c}\text { Percent } \\
\text { burned }\end{array}$ \\
\hline Excavation & 6852 & 1082 & 18 & 3481 & 51 \\
\hline Flotation & 3033 & 80 & 6 & N/A & N/A \\
\hline
\end{tabular}

Table 6. Number and Percentage of Identified Faunal Remains from 1997 Excavations

\begin{tabular}{|l|c|c|}
\hline \multicolumn{1}{|c|}{ Identification } & Number identified (NISP) & Percentage of assemblage \\
\hline Fish & 39 & 3.4 \\
\hline Reptiles & 9 & 0.8 \\
\hline Birds & 5 & 0.4 \\
\hline Small Rodents & 78 & 6.7 \\
\hline Leporids (rabbits and hares) & 987 & 85 \\
\hline Carnivores & 4 & 0.3 \\
\hline Artiodactyls & 40 & 3.4 \\
\hline
\end{tabular}


identified specimens are rodents including squirrels, pocket mice, deer mice, cotton rats, pocket gophers, and kangaroo rats; carnivores including coyote and badger; birds including quail, perching birds, and indeterminate species, reptiles including terrestrial turtles and non-venomous snakes, and small, indeterminate fish that are most likely minnows or suckers based on the size of the vertebra recovered. These percentages are presented in Table 6 and include the identified material from excavated contexts and flotation procedures.

Preliminary analyses of the faunal remains recovered from the 1998 excavations show patterns similar to those reported above. Analysis of 486 faunal remains from a single terrace (T163) show similarities in composition, percentage, and appearance to faunal remains analyzed from features identified during the 1997 excavations. The T163 fauna indicate that jackrabbits (Lepus spp.), cottontail rabbits (Sylvilagus spp.), large mammals (including pronghorn [Antilocapra americana], mule deer [Odocoileus hemionus], and unidentified artiodactyls), and a variety of small mammals were important game species. Additionally, a single turtle carapace fragment (Terrapene sp.) and a small fish element have been identified from this terrace. Although the 1998 analysis is preliminary, percentages are clearly similar to the 1997 excavations (Table 7).

In addition the small faunal material from all 1998 heavy fractions has been examined. This material sugests a greater recovery in number and percentage of fish, small mammals, and reptiles compared with the 1997 remains. This increase suggests that the con- tribution of aquatic resources may be more significant than previously suspected, but that the material may be difficult to recover in excavation practices. If this is the case, materials recovered from flotation procedures may be especially important to overall assessments of subsistence practices at Cerro Juanaqueña.

The faunal remains from Cerro Juanaqueña include similar taxa as those recovered from other early agricultural sites in the southwestern United States and northwestern Mexico, possibly indicating a similar set of exploited resources throughout the area. However, a possible difference between Cerro Juanaqueña and other sites occupied in the greater Southwest may be in the manner and frequency in which artiodactyls were exploited since they are not abundant in the assemblage. At Cerro Juanaqueña the ratio to artiodactyls to leporids is lower than at most sites in the Southwest or Northwest as they are generally the second most abundant taxa (Bayham 1982; Lang and Harris 1984; Olsen 1982). For example, artiodactyls are far more common at sites in southeastern and south-central Arizona than at Cerro Juanaqueña (Bayham 1982; Greene and Mathews 1976; Huckell 1995; Schmidt et al. 1998; Szuter and Bayham 1989).

Of the 1,242 identified specimens at Cerro Juanaqueña, only 43 are artiodactyl. Twenty-four of the artiodactyl remains are indeterminate, a designation based largely on small tooth fragments, 13 are indeterminate deer, one is mule deer and five are pronghorn. There are several possible explanations for the low artiodactyl relative abundance at Cerro Juanaqueña in comparison to other sites in the greater Southwest.
Table 7. Summary of Faunal Remains from Terrace 163, 1998 Excavations

\begin{tabular}{|l|c|c|}
\hline Identification & Number identified (NISP) & Percentage of assemblage \\
\hline Fish & 1 & 1.25 \\
\hline Box Turtle & 1 & 1.25 \\
\hline Pocket Mouse & 1 & 1.25 \\
\hline Chipmunk & 1 & 1.25 \\
\hline Indeterminate Canid & 1 & 1.25 \\
\hline Cottontail rabbit & 13 & 16 \\
\hline Jackrabbit & 59 & 74 \\
\hline Pronghorn & 1 & 1.25 \\
\hline Indeterminate Artiodactyl & 2 & 2.5 \\
\hline Unidentified & 406 & - \\
\hline
\end{tabular}

First, large game, for whatever reason(s), may not have been available to the inhabitants of Cerro Juanaqueña. But, the fact that the ecological zones characteristic of this geographic area were similar to other areas that adequately supported artiodactyl populations renders this explanation insuffi- 
cient. It is also possible that local artiodactyl populations were impacted by human predation, although evidence of resource depression cannot presently be evaluated. Another possible explanation for the lack of artiodactyls is that the inhabitants chose not to use these resources in favor of small game, culturally not selecting for the use of large game. This alternative explanation is unlikely, as it entails people foregoing resources which provide much higher post-encounter net caloric returns than those provided by smaller game (Broughton, 1994a, 1994b; Szuter and Bayham 1989). The final explanation for the near absence of artiodactyl remains is that these resources were procured and processed at a location away from the site proper.

Some researchers (Binford 1978; Kent 1991; Schmidt 1999; Szuter and Bayham 1989) have discussed specialized activity areas located at some distance from primary areas of occupation. These small sites or caves appear to have been used specifically as animal processing areas, and often leave little in the way of tools or debitage. If the inhabitants of Cerro Juanaqueña used similar types of activity areas, we would not expect abundant artiodactyl remains at the site. Ultimately, other lines of evidence (geomorphological and paleoclimatological), and larger sample sizes obtained through additional excavations and analysis may provide evidence to support one or a combination of these hypotheses.

\section{Macrobotanical Remains}

A principle goal of the 1998 field season was to obtain additional botanical remains for both ethnobotanical analysis and for radiocarbon dating. Although macrobotanical returns were generally low from the 1997 field season, the deeper deposits were the most productive. For this reason, the 1998 excavation strategy placed emphasis on recovering flotation samples from deposits $50 \mathrm{~cm}$ or more below the surface. In fact, individual terraces were selected for testing in 1998 based, in part, on their the potential for yielding deep deposits.

In 1998, we took 163 float samples during excavation and floated them in the field lab, using the decanting method for field flotation. When water is added to the sample, the organic material floats to the surface, and the water is then poured through a $.5 \mathrm{~mm}$ geological sieve. The light fraction is then carefully removed from the screen and allowed to dry. The heavy fraction, containing gravels, was retained to examine for small faunal remains and microlithics. Fifty light fractions were submitted to Karen Adams of the Crow Canyon Archaeological Research Center for analysis. The following results are based upon that analysis.

The 1998 flotation samples were far more productive than the 1997 samples in that ten out of twelve features excavated produced charred reproductive plant parts. While the 1997 data implied that corn may have been less important at Cerro Juanaqueña than indigenous small seeded species, 1998 findings suggest that maize (Zea mays) agriculture played a significant role in the diet. Five charred cob fragments, four cob segments, and six kernel fragments were recovered from the screen during excavation in 1998, and similar remains, including maize cupules, were found in 42 of 50 flotation samples ( 84 percent, Table 8 ). Of the flotation material, 13 maize cupules and five kernel fragments came from Cerro los Torres and Cerro Vidal. The maize is a 12-rowed variety consistent with maize found at archaeological sites throughout the Southwest and northern Mexico, including other Late Archaic sites. The close proximity of the Rio Casas Grandes suggests that the inhabitants practiced floodplain agriculture.

As shown in Table 8, the next most common plants recovered were chenopodium or amaranth (chenoams), which occurred in 20 of 501998 flotation samples (40 percent). Other charred seeds found in the 1997 or 1998 samples include wild gourds (Cucurbita digitata or C. foetidissima type), unidentified grasses (Gramineae), bulrush (Scirpus sp. type), chia (Salvia sp. type), plains lovegrass (Eragrostis intermedia type), milk-vetch (Astragalus nutulliana type), globe-mallow (Sphaeralcea sp.), and Monocotyledon. Additional taxa found in 1998 that were not recovered in 1997 include Trianthema, Ferocactus, Physalis, and Euphorbia sp. type. Most of these taxa are known to be potentially economic seed plants, indicating that nondomesticated species played an important role in the diet as well. 
Table 8. Charred Reproductive Parts

\begin{tabular}{|c|c|c|c|}
\hline Taxa & $\begin{array}{c}1998 \text { Ubiquity } \\
\text { (from flotation) }\end{array}$ & $\begin{array}{l}1997 \text { Ubiquity } \\
\text { (from flotation) }\end{array}$ & \begin{tabular}{|c|}
$\begin{array}{c}\text { Features (both flotation } \\
\text { and screen) }\end{array}$ \\
\end{tabular} \\
\hline Zea mays & 0.84 & 0.05 & $\begin{array}{l}\text { T10,T97,T126,T163, } \\
\text { T222,T290,T297, T387, } \\
\text { T413,T537, CV-T20, LT } \\
\text { T1 }\end{array}$ \\
\hline Cheno-am & 0.4 & 0.2 & $\begin{array}{l}\text { T6,T10,T97,T126, } \\
\text { T163,T222,T387,T537, } \\
\text { CV-T20,LT-T1 }\end{array}$ \\
\hline Gramineae & 0.14 & 0.07 & $\mathrm{~T} 10, \mathrm{~T} 222, \mathrm{~T} 387, \mathrm{LT}-\mathrm{T} 1$ \\
\hline Scirpus & 0.06 & 0.02 & $\mathrm{~T} 10, \mathrm{~T} 222, \mathrm{~T} 387$ \\
\hline Trianthema & 0.04 & - & $\mathrm{T} 10, \mathrm{~T} 387$ \\
\hline Ferocactus & 0.02 & - & $\mathrm{T} 97$ \\
\hline Salvia & 0.02 & 0.07 & $\mathrm{~T} 163, \mathrm{~T} 222$ \\
\hline Monocotyledon & 0.02 & 0.02 & $\mathrm{~T} 222, \mathrm{~T} 387$ \\
\hline Eragrostis intermedia & 0.06 & 0.07 & T222,LT-T1 \\
\hline Physalis & 0.06 & - & LT-T1 \\
\hline Euphorbia & 0.02 & - & LT-T1 \\
\hline Astragalus nuttalliana & - & 0.05 & $\mathrm{~T} 222$ \\
\hline Cucurbita digitata & - & - & $\mathrm{T} 222$ \\
\hline Sphaeralcea type & - & 0.02 & $\mathrm{~T} 222$ \\
\hline
\end{tabular}

In her preliminary analysis of the cheno-ams, Gayle Fritz, Associate Professor at Washington University, has identified charred amaranth and chenopodium. While the chenopodium from Cerro Juanaqueña is nondomesticated, scanning electron microscope work indicates thin seed coats on some of the amaranth specimens from Cerro Juanaqueña, Cerro Vidal, and Cerro los Torres, suggesting that at least some of the amaranth may represent a domesticated variety. Domesticated amaranth has been documented from a number of Hohokam sites throughout the American Southwest and in Late Archaic contexts at Fresnal Shelter in southern New Mexico (Fritz 1984; Tagg 1996). However, if some of the amaranth from Cerro Juanaqueña proves to be domesticated, it would be the first documented case of domesticated amaranth in northwestern Mexico at such an early date. These results are preliminary, and Dr. Fritz is continuing her analysis.

In addition to charred reproductive parts, flotation and excavation also produced wood charcoal from plants such as mesquite (Prosopis sp. type), saltbush (Atriplex type), Leguminoseae, Compositae type, ocotillo (Fouquieria type), and creosote bush (Larrea type). These taxa are listed in Table 9. The most common wood charcoal was mesquite, which makes a superior fuelwood. Also, ocotillo is commonly used as a building material.

Table 9. Wood Charcoal

\begin{tabular}{|c|c|c|c|}
\hline Taxa & $\begin{array}{l}1998 \text { Ubiquity } \\
\text { (from flotation) }\end{array}$ & $\begin{array}{c}1997 \text { Ubiquity (from } \\
\text { flotation) }\end{array}$ & $\begin{array}{c}\text { Features (both flotation and } \\
\text { screen) }\end{array}$ \\
\hline Prosopis & 0.02 & 0.22 & T6, T163, T222, T387, LT-T1 \\
\hline Atriplex & 0.02 & 0.05 & T222, T387, LT-T1 \\
\hline Leguminoseae & 0.02 & 0.17 & T6,T222,T537, LT-T1 \\
\hline Compositae type & --- & 0.02 & T222 \\
\hline Fouquieria type & --- & 0.05 & $\mathrm{R} 250, \mathrm{~T} 6, \mathrm{~T} 222$ \\
\hline Larrea type & --- & 0.1 & $\mathrm{~T} 222, \mathrm{~T} 537$ \\
\hline
\end{tabular}




\section{Human Remains}

For the first time, in 1998 we recovered two or three fragments of human bone from T10. These pieces include a cranial fragment, and a tooth (lower premolar). All were recovered from a single level in T10. These remains, although few, suggest that burials are present at Cerro Juanaqueña.

\section{Pollen Analysis}

Pollen samples were submitted for analysis with two principal objectives: 1) recognition of environmental change, and 2) identification of economic activities such as cuiltivation and/or processing of food plants. Ten samples were submitted to Dr. Suzanne Fish, Arizona State Museum, University of Arizona for analysis (Table 10). Five of these samples were from dated soil horizons or depositional units located at various depths in the floodplain (Table 10, Samples 2 through $6)$. Three samples were pollen washes from a stone bowl, a metate, and a mano recovered during excavations on Cerro Juanaqueña. Another sample was taken from midden deposits behind one of the terraces on Cerro Juanaqueña. The tenth sample was taken from the surface of the floodplain, in an old field which had been fallow for several years. This sample provides an indication of pollen results which modern conditions are likely to yield.

Results of the pollen analysis are presented in Table 11 (Fish 1999). One of the samples had insufficient pollen for analysis (see Table 10, Sample 5 from BHT16, dated 1980 в.P.). Another of the floodplain

Table 10. 1997 Pollen Samples

\begin{tabular}{lllr}
\hline Number & Location & Context & Age (BP) \\
\hline 1 & Floodplain & Modern Surface, Jorge Terrace & 0 \\
2 & BHT6 & C5b, Alluvial deposits & 590 \\
3 & BHT10 & Ab2, Viejo Paleosol & 1420 \\
4 & BHT12 & Ab, Janos Paleosol & 1860 \\
5 & BHT16 & Ab, Janos Paleosol & 1980 \\
6 & BHT2 & AbK, Trincheral Paleosol & 3140 \\
7 & T6 & Stone Bowl & 3000 (est.) \\
8 & T6 & Metate & 3000 (est.) \\
9 & T6 & Mano & 3000 (est.) \\
10 & T167 & Midden & 3000 (est.)
\end{tabular}

samples (see Table 10, Sample 2 from BHT6, dated 590 в.P.) yielded results not directly applicable to local environmental reconstruction. Although only about 600 years old, this sample had high frequencies of pine, oak, and juniper pollen, species which were almost certainly not common in the vicinity of Janos at A.D. 1400. Geological evidence indicates that this sample comes from alluvial deposits which were laid down during a time of rapid deposition. We believe that the pine and oak pollen originated in the headwaters of the drainage, was transported in water, and was then deposited on the floodplain along with other supended sediment. Such water transport and deposition of pollen is a well-documented phenomenon. For this reason Sample 2 is disregarded in the following discussion.

Prevailing models of paleoenvironmental conditions in Chihuahua are based primarily on analysis of packrat middens (Spaulding and Graumlich 1986; Van Devender et al. 1987; Van Devender 1990) supplemented by information from other sources (Metcalfe et al. 1997; Krider 1998). All of these models agree that climatic conditions approximating those of modern times were established by about 4500 в.P. For this reason we expected that the analyzed pollen would reflect plant species which are present in the area today. However, it did seem possible that relatively minor changes in climate which could have affected vegetation might have occurred in the past 3000 years (Krider 1998; Van Devender and Worthington 1977; Van Devender 1995). Human activities may also have affected vegetation in ways which could have altered pollen rain. For example, with increasing cultivation we might expect increased frequencies of cheno-ams, composites, and other plants which grow in disturbed areas. It also seemed possible that centuries of fuelwood gathering could have reduced arboreal species such as cottonwood and mesquite.

Pollen samples from soil horizons buried in the floodplain span the past 3000 years, and seem to reflect conditions very similar to those which prevail today in anthropogenic landscapes. Cheno-ams and composites 
Table 11. Percentages of Pollen Grains by Taxa

\begin{tabular}{|c|c|c|c|c|c|c|c|c|c|}
\hline Taxa & \multicolumn{9}{|c|}{ Sample Number } \\
\hline & 1 & 2.\# & 3 & 4 & 6 & 7 & 8 & 9 & 10 \\
\hline Zea mays & & & & & & & & $\&$ & \\
\hline Gramineae & 9 & 15 & 2.5 & 4.5 & 21.5 & 2 & 3 & 1.5 & 2.5 \\
\hline Compositae & & & & & & & & & \\
\hline High Spine & 19.5 & 2.5 & 5 & 3.5 & 4 & 3.5 & 7 & 2 & 6.5 \\
\hline Low Spine & 16 & 11.5 & 30.5 & 27 & 19.5 & 21.5 & 22.5 & 18.5 & 16 \\
\hline Cheno-Am & 39.5 & 28 & 47.5 & 43 & 28 & $49.5^{*}$ & $53.5^{*}$ & 6.5 & $58.0^{*}$ \\
\hline Boerhaavia-type & + & 1 & 2 & 3 & + & 6 & 0.5 & + & $4.0^{*}$ \\
\hline Sphaeralcea & & & & 1 & 0.5 & + & 0.5 & & 2.5 \\
\hline Kalistroemia & & & + & + & & + & + & + & 1 \\
\hline Onagraceae & & & & 0.5 & & & + & & \\
\hline Eriogonum & & 2 & 1 & & & 1.5 & + & & 0.5 \\
\hline Euphorbia-type & & & & & & & 0.5 & + & \\
\hline Solanaceae & 0.5 & & & & & & & & \\
\hline Labiatae & & & & & 0.5 & & & & \\
\hline Tidestromia & & 0.5 & & & & & & & \\
\hline Cyperaceae & & & & & 0.5 & & & & \\
\hline Typha & & 2 & & & & & & & \\
\hline Liguliflorae & & & 0.5 & & & & & 0.5 & \\
\hline Umbelliferae & & & & 0.5 & & 0.5 & & & \\
\hline Cylindropuntia & & & & & & & + & + & \\
\hline Platyopuntia & & & & & & & & + & \\
\hline Cereus-type & & & & & & & & + & 0.5 \\
\hline Artemisia & & 1.5 & 4 & 3 & 1 & 1.5 & 2 & 2.5 & 2 \\
\hline Larrea & & & 0.5 & & & & 1.5 & 0.5 & \\
\hline Prosopis & & + & & 1 & & 0.5 & & & \\
\hline cf. Leguminosae & 0.5 & & & & & & & & \\
\hline Ephedra & & & 1 & 1 & 0.5 & 2 & & 1 & 1.5 \\
\hline Cephalanthus & & 0.5 & & & & & & & \\
\hline Celtis & & & 0.5 & & & & & & \\
\hline Agave & & & & & & & & & + \\
\hline Pinus & 6 & 35.5 & 1.5 & 3.5 & 4.5 & 3 & 0.5 & 2 & 1.5 \\
\hline Quercus & 3 & 14 & 0.5 & 2.5 & 8.5 & 1.5 & 1 & 2.5 & $*$ \\
\hline Juniperus & 2.5 & + & 1 & 0.5 & 4 & 0.5 & + & & \\
\hline \begin{tabular}{|l} 
Salix \\
\end{tabular} & + & 1.5 & 0.5 & 1 & 1.5 & & & 1 & \\
\hline Alnus & & 2.5 & & 0.5 & + & 0.5 & & & \\
\hline Indeterminate & 4 & 5.5 & 1.5 & 4 & 6 & 6 & 7.5 & 3 & 3.5 \\
\hline
\end{tabular}

\# Sample rejected

+ Pollen type observed only in scanning material after tabulation of the 200 grain standard sum.

* Pollen type occurring in aggregates of 6 or more grains.

\& Cultigen pollen tabulated as number of grains rather than percentage, and excluded from sum per standard procedures.

dominate all of these samples, accounting for between 51.5 percent and 83 percent of the pollen. It is interesting that the frequency of these plants is lowest in the sample associated with a date of 3140 в.Р. (Sample $6)$, which has a corresponding increase in grass pollen (Gramineae). This sample location may represent a more mesic microhabitat favoring grass or the growth of grass in a fallow section of a cultivated area. Distinguishing among these alternatives requires further corroboration. Pine (Pinus), oak (Quercus) and juniper (Juniperus) are consistently present, ranging from 3 percent to 17 percent in the floodplain deposits, with 
11 percent found in the sample from the modern surface. These species do not grow in the immediate vicinity of Janos today, but are common at higher elevations. These frequencies can be primarily attributed to aeolian and perhaps secondarily to alluvial transport and deposition.

Willow (Salix) is a riverine species which is found in all of the floodplain deposits. There is no indication in the pollen record that either mesquite (Prosopis) or cottonwood (Populus) were ever significantly more common than today. Cottonwood pollen is a fragile type, however, and is normally recovered only under optimal conditions of preservation. Mesquite pollen occurrs only intermittantly, but such a record is not unusual for this naturally infrequent pollen type. Pollen from prehistoric contexts does include more aquatic plants than the modern sample. Sedge (Cyperaceae), cat-tail (Typha), and members of the parsley family (Umbelliferae) are all present in prehistoric samples, hinting that there may have been more permanent water in the Janos area. Cat-tail requires permanently damp conditions which could have been natural or the result of artificial impoundments by farmers. (The only Umbelliferae which we have identified in the modern vegetation is water parsnip, Berula erecta.)

The pollen washes from ground stone artifacts found on Cerro Juanaqueña and the sample from midden deposits behind Terrace 167 are similar to those from the floodplain in that they are dominated by Chenoams. These taxa are typically prominent in the culturally disturbed environs of prehistoric habitation in the Southwest. However, several species are present in these samples which are not found in the floodplain samples, including spurge (Euphorbia-type), cholla (Cylindropuntia), prickley-pear (Platyopuntia), hedgehog or related cacti (Cereus-type), and agave (Agave). Most of these are succulent plants which typically grow on rocky hillslopes; because relatively rare cactus and agave pollen is seldom recovered in samples from natural vegetation, these types likely reflect resource residues. Dr. Fish did note that Cheno-am pollen from the bowl, metate, and midden samples and the Boerhaavia-type pollen from the midden occurred in aggregates of six or more grains. Large clusters of pollen like these are not efficiently transported by wind, and the occurrence of aggretages could indicate a relatively immediate plant source for the pollen, or could indicate the direct introduction of immature floral parts by human beings. Chenopodium and Amaranth are both economically important species, which could have been processed in stone bowls and metates, although both also grow on Cerro Juanaqueña today.

\section{Summary and Conclusions}

\section{Period of Occupation}

In the Solucitud for this project which was submitted to the Consejo de Arqueologia in April 1998 we identified several important research objectives. One of these was to determine more precisely the period of occupation at Cerro Juanaqueña. In the past year we have obtained two additional radiocarbon dates, and we are awaiting results from eight additional samples which have been submitted for dating. The results obtained so far confirm that major occupation of the site was around 1150 в.c. Furthermore, present indications suggest that the occupation was relatively brief, perhaps no more than 200 years. Cerro los Torres appears to be contemporaneous with Cerro Juanaqueña based upon an 1120 в.c. radiocarbon date. Cerro Vidal, however, appears to date to 100 в.C.

\section{Subsistence}

Subsistence was another issue which we proposed to explore. One of our most important findings during the 1998 field season was the ubiquity of maize. Maize has now been found in 13 of the 16 features which we have excavated, leaving little doubt that maize agriculture was one of the mainstays of the Late Archaic subsistence system in northwestern Chihuahua. In addition, the size of the manos is consistent with that of a group that acquires a substantial proportion of its diet from maize processing, yet less than that of a fully agricultural society.

The tentative identification of domesticated amaranth is another very exciting development which raises a 
number of new possibilities. Despite the occurrence of cultigens, it is clear that wild plant foods also contributed to the diet of Late Archaic peoples at Cerro Juanaqueña. Other charred plants recovered at the site include: chenopodium, wild gourds, unidentified grasses, bulrush, chia, plains lovegrass, milk-vetch, globe-mallow, Monocotyledon, Trianthema, Ferocactus, Physalis, and Euphorbia sp. Most of these taxa are known to be potentially economic seed plants, indicating that nondomesticated species played an important role in the diet as well.

Faunal analysis shows an overwhelming reliance on rabbits as over 90 percent of the identifable bone from 1997 and one terrace (T163) from 1998 excavations are Lagomorphs. Jackrabbit is almost ten times more common than cottontail. Other species found in cultural deposits represent less than 10 percent of the identifiable bone including mule deer, pronghorn antelope, squirrels, pocket mice, deer mice, cotton rats, pocket gophers, kangaroo rats, coyote, badger, quail, perching birds, turtles, snakes, and small fish.

Surprisingly we are finding numerous small bones from fish, reptiles, and rodents in the heavy fraction portion of the flotation samples, a procedure which recovers bone smaller than $1 / 8 \mathrm{inch}$. This material from 1998 has all been examined and shows an increase in the number and percentage of fish, small mammals, and reptiles relative to the 1997 results. This increase suggests that the contribution of aquatic resources may be more significant than previously suspected. The faunal remains thus far identified at Cerro Juanaqueña are similar to assemblages recovered at other early agricultural sites in the southwestern United States and northwestern Mexico, possibly indicating a similar set of exploited resources throughout the area.

\section{Sedentism}

Sedentism and mobility are two other closely related issues which we hope to investigate. We have developed labor estimates which show that construction of the walls and terraces at Cerro Juanaqueña would have required approximatley 30 person years. This observation, combined with the apparently brief period of construction and use of the site, certainly suggests that the site was built and used by a relatively sedentary population. The discovery that significant quantities of maize are present also reinforces the view that at least some part of the population was spending a significant amount of time at the site. Under current climatic conditions corn is planted in June, cared for during the growing season, and harvested in September. Storage is one of the important properties of a maize diet, and we assume that a large part of the annual crop was put aside for consumption during the lean winter and early spring months. Charred Astragalus seeds imply occupation in the spring, since this is an early flowering species. These lines of evidence suggest that at least some part of the population was present from spring through fall, and most likely into the winter as well. Finally, the chipped stone technology at Cerro Juanaqueña suggests a relatively sedentary lifeway. In general bifacial technologies which formal, curated took kits are associated with highly mobile settlement systems, while people following more sedentary ways of life usually have very expedient, informal lithic technologies (e.g.; Kelly and Todd 1988; Vierra 1993, 1996). The assemblages which we have analyzed from Cerro Juanaqueña are expedient and therefore suggest sedentism. None of the arguments presented here provide specific and quantifiable information about numbers of people or lengths of stay at the site, but they do suggest a relatively high degree of sedentism and are not consistent with the highly mobile settlement pattern which used to be thought of as a central characteristic of the Late Archaic period.

\section{Aggregation}

Population aggregation is another important issue at Cerro Juanaqueña. Most previous models of early agricultural times in this part of the continent have envisioned small villages at most. It has long been thought that larger villages did not develop in this region until much later in time, A.D. 500 to 700 in some areas and as late as A.D. 1200 in other areas (e.g. Hard et al. 1996). However, we believe that Cerro Juanaqueña and perhaps other cerros de trincheras in northwestern Chihuahua were built and occupied by relatively large groups of people, perhaps several hundred or more. 
Large macrofeatures are present at Cerro Juanaqueña, Cerro los Torres, and Cerro Vidal. These are large terrace/wall complexes which form continuous features bounding the sites on several sides. The macrofeature at Cerro Juanaqueña is $400 \mathrm{~m}$ long, and defines the northern, eastern, and southern margins of the terraced area. At Cerro los Torres an $800 \mathrm{~m}$ long macrofeature completely encircles the feature complex. Cerro Vidal is actually composed of a series of concentric macrofeatures, with the outermost bounding the site on the north, east, and south and reaching a length of $500 \mathrm{~m}$. These features imply levels of planning and leadership which we do not usually associate with simple early agricultural communities. Furthermore, they bound areas up to 6 ha. in size. Although we cannot yet develop a quantitative estimate on the basis of this observation, there is a clear implication that these formally defined spaces accommodated the spatial needs of large groups of people.

Another approach to estimating the size of the group occupying Cerro Juanaqueña is through estimation of the amount of wear on metates. Based on a systematic sample, we estimate that there are 300 deep basin metates on the site, with an average of $8.2 \mathrm{~cm}$ of wear. Experimental data show that basalt metates are worn down at a rate of $.5 \mathrm{~cm} /$ year (Hard and Roney 1998b). These calculations imply an amazing 28,000 person years of occupation at the site. This number, 28,000 (I) should equal the average number of people who lived on the site in a given year $(\mathrm{P})$ multiplied by the number of years of occupation on the site (A), multiplied by the proportion of the year during which the site was occupied (F): I = P x A x F. If we assume that the site was occupied for 9 months each year $(\mathrm{F}=.75)$ and that the site was occupied for 200 years $(A=200)$ then the average population at the site $(\mathrm{P})$ is 187 people $(\mathrm{P}=28,000 /(200 \times .75))$. We expect to refine these numbers as our research progresses.

\section{Function of the Terraces}

Our 1998 findings with regard to terrace function is consistent with those from 1997. The presence of heavily worn ground stone tools, burned and unburned bone, dense chipped stone, and ashy deposits are all consistent with a function as a residential house plat- forms, although we have yet to identify house remains. The function of the rock rings remains unknown. In 1999, with permission from the Consejo, we hope to expose large areas on selected terraces and rock rings, a strategy which we believe will be more likely to reveal cultural features such as structures, storage pits, hearths, etc. (A. Villalpando and R. McGuire 1998, personal communication). In contrast, our 1998 excavations were small in size and were directed toward achieving maximum depth.

We have developed labor estimates for construction of the terraces at Cerro Juanaqueña which imply that the terraces were not built primarily for agricultural purposes. For example, the construction costs of the flat areas behind the terraces is about 4300 person days per hectare. This even exceeds the estimated labor costs of constructing Maya raised fields! In addition, if the total area of potential farm land behind the 486 terraces on Cerro Juanaqueña were planted in maize the harvest would feed only about four adults for a year. While we estimate a single terrace could be built in only about 130 hours, the labor to build all of the terraces is about 30 person years or similar to that required to build a 600 room pueblo or 135 large pithouses.

\section{Use of the Floodplain}

Dr. Nordt has made excellent progress toward understanding the history of the floodplain of the Rio Casas Grandes in the vicinity of Janos. A detailed picture of the sequence of erosion and deposition spanning the past 14,000 years has been developed. This sequence includes Pleistocene alluvial terraces and fans, a 9000 year old peat layer, and five paleosols dating to 4500 B.P. (Antonio paleosol), 3600 в.P. (Pedro paleosol), 3100 в.Р. (Trincheras paleosol), 2200 в.P. (Janos paleosol), 1400 в.Р. (Viejo paleosol). This information will tell us much about environmental change in northwestern Chihuahua since the last glacial period. Unfortunately it appears that a large part of the 3000 year old surface, the surface which is contemporary with occupation of Cerro Juanaqueña, has been removed by erosion, although remnants remain on both sides of the Rio San Pedro near its confluence with the Rio Casas Grandes. 
Pollen from buried soil horizons dated by humates and charcoal suggests that for the past 3000 years the floodplain looked much as it does today. Aquatic plants are represented in the prehistoric samples, though, suggesting that there may have been more permanent water, but otherwise the pollen record is consistent with modern conditions. We did not find evidence of maize or other cultigens in any of the floodplain pollen samples, including the modern control sample.
In summary, in the span of two years of fieldwork we have made dramatic progress in understanding Late Archaic adaptations. However, many questions remain which will be pursued, with the permission of the Consejo in 1999 and 2000. 


\section{Appendix 1: Cerro Juanaqueña Feature Descriptions}

\section{Terrace 10}

\section{Description}

Terrace 10 (T10) is a large 18 meter wide by 13 meterlong feature located in the northeastern quadrant of the site. The length of the terrace wall is $21 \mathrm{~m}$, and the surface area is approximately $56 \mathrm{~m}^{2}$. This terrace is constructed of an estimated $27 \mathrm{~m}^{3}$ of sediment and rock. The depth of the berm wall to bedrock is 1.25 meters. Terrace 9a lies to the south of T10, T18 is upslope and to the west, and T89a is located downslope to the northeast. A number of surface artifacts were present, including 7 metates and fragments, and 3 manos.

Our decision to test this terrace was guided by the following factors: Terrace 10 is geographically isolated from other previously tested features. The steep pitch of the talus slope suggests that this terrace would yield deep cultural deposits. The terrace berm is wellconstructed, and the surface area is substantial and well-preserved. Another indicator was the dark color (10YR 5/3) of the surface sediments. The combination of these indicators suggested that this terrace had been intensively occupied.

\section{Excavation strategy}

Two one by one meter units were located on T10. In an effort to define T10's horizontal and vertical boundaries, Unit 1 was located approximately 2 meters north of T9a and abutted the terrace berm to the west. Unit 2 was located adjacent and to the west of Unit 1 . The units were simultaneously excavated to bedrock and proceeded in arbitrary $10 \mathrm{~cm}$ levels. When bedrock was encountered, the final level was excavated as a natural level to bedrock. Unit 1 was excavated to a final depth of $1.25 \mathrm{~m}$ below surface, and Unit 2 was excavated to $90 \mathrm{~cm}$ below surface.

\section{Stratigraphy}

Zone 1, or the lower-most layer, was between 35 and $55 \mathrm{~cm}$ thick and consisted of a dark, grayish brown (10YR4/2) sediment. The lower boundary of this zone is well-defined by the sloping bedrock. The west-end of this zone was about $35 \mathrm{~cm}$ thick, and the east-end about $55 \mathrm{~cm}$ thick. The zone extended from between $45-80 \mathrm{~cm}$ (west-end) and 60-120 cm (east-end) below surface. This variance was primarily the result of the sloping bedrock. Zone 1 contained a large number of fist-size rocks and a few larger rocks $(\geq 40 \mathrm{~cm})$. Numerous artifacts were recovered from this zone, including: charcoal, maize, bone, lithics, human bone, and a projectile point. Zone 2 consisted of a brown (10YR5/3) sediment with a high gravel and ash content. This layer was loose and lacked structure, and the rocks were smaller than fist-size. A few larger rocks $(\geq 40 \mathrm{~cm})$ were noticeable in Unit 2, but these are probably the result of displacement, rather than original terrace construction. The uppermost layer, or Zone 3, was not well-defined in profile, but discernible in its content of small gravels, ranging between $.5 \mathrm{~cm}$ and 2 $\mathrm{cm}$ in diameter. This layer of sediment is likely the result of colluvium.

\section{Artifacts}

The most significant artifacts from this terrace were the human bones recovered from Unit 2, Level 7. The bones consisted of a phalanx (possibly human), a very large pre-molar and a cranial fragment. Unit 1 material included a ground stone fragment from Level 2, a mano and metate from Level 6, and maize from Level 11. Maize was also recovered from Unit 2, Level 5 and Level 8 . The majority of the cultural material recovered from Unit 1 and Unit 2 consisted of lithic and bone fragments. In both Unit 1 and 2, bone was absent from within the first level excavated.

Flotation samples from Unit 1 were secured from Level 2 and then from Levels 5 through 12. The phalanx 
was recovered from a flotation sample of Unit 1, Level 7. Flotation samples from Unit 1, Level 11 yielded maize and charcoal, and another charcoal sample from Level 12. The Unit 1, Level 11 maize was identified as a Zea mays cob fragment, and was submitted for radiocarbon dating. The Unit 2 flotation samples were taken from Levels 5 through 9. Maize and charcoal were found in the Level 5 sample, and another charcoal fragment from the Level 8 sample. The macrobotanical results from flotation samples for Unit 1, Levels 10,11 , and 12 (100 to $120 \mathrm{~cm}$ below surface), were the most productive. A total of 65 speci- mens were identified: Zea mays (53); Graminae (6), Cheno-am (2), Scirpus (2), and Trianthema (2). In contrast, the Unit 2 flotation samples proved very unproductive. Only 1 Zea mays cob fragment was recovered (previously noted) from Level 5. This rather wide disparity in macrobotanical remains, between units, did not carry-over into other cultural material such as lithic and bone.

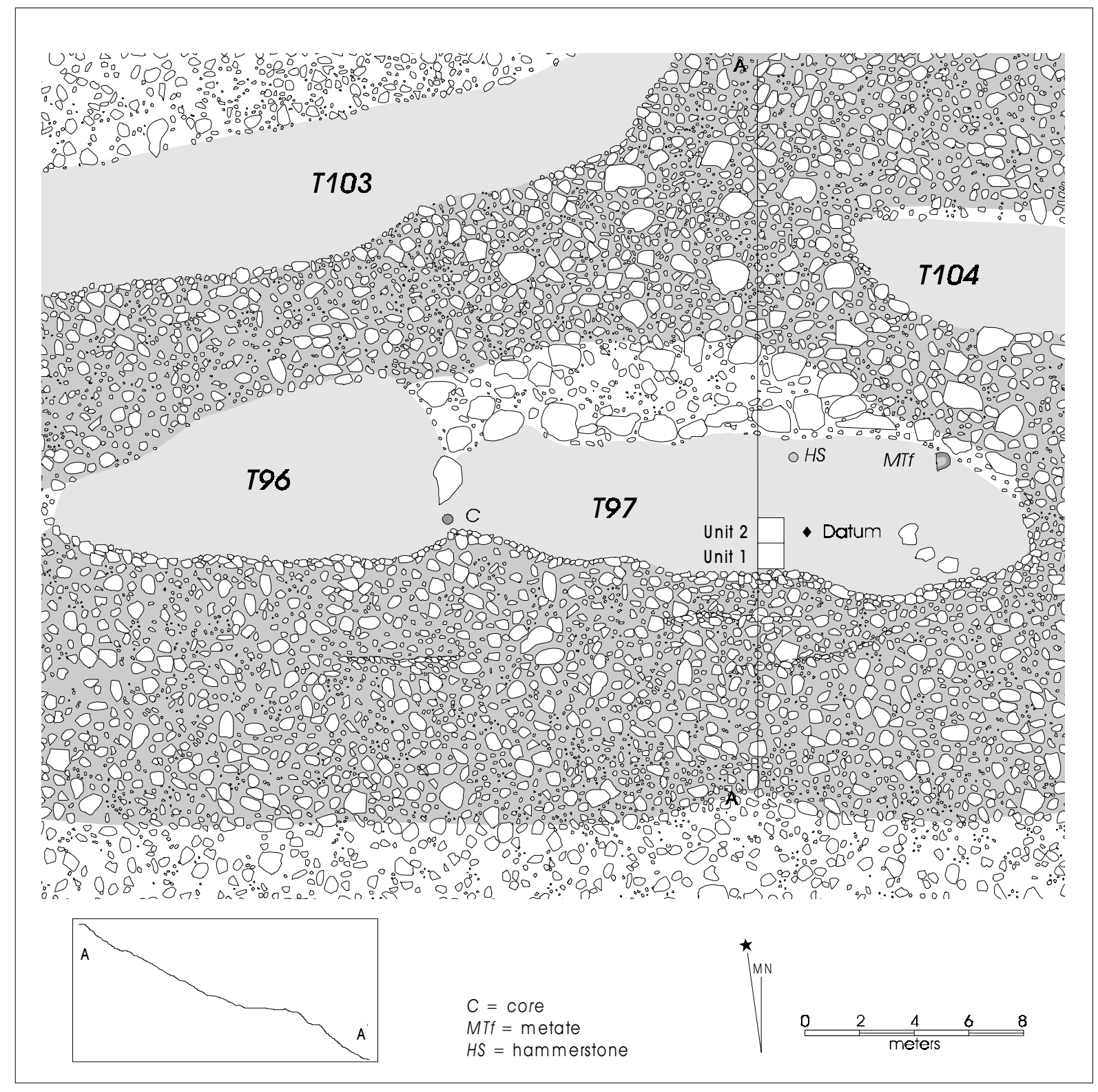

Figure 13. Plan view of T97. 


\section{Interpretation}

The T10 stratigraphy reflects a typical terrace construction sequence. The lower-most zone, Zone 1 appears to represent the terrace leveling bed. This fill episode is comprised of sediments with small to largesize rocks, and a rather high artifact density. The density and assortment of artifacts recovered from this zone appear to be the result of bioturbation, erosion, and gravity. Colluvial deposits were not encountered between this lower-most zone and bedrock. This would indicate that bedrock was exposed at time of initial construction. Although lacking a definable surface, Zone 2 is reflective of an occupation surface which exhibits a uniform mixture of ashy deposits, lithic material, and bone. This artificial fill consisted of sediments with small to fist-size rocks, and very few larger $(40 \mathrm{~cm})$ rocks. The uppermost zone, Zone 3, is comprised of colluvial sediments and gravels that was deposited after the terrace was abandoned.

\section{Terrace 97}

\section{Description}

T97 is located on the southern side of Cerro Juanaqueña, and faces almost due south, with a slight bearing to the east. At about 39 meters below the summit, it is one of the lowermost terraces of the upper terrace zone (Figures 13 and 14). T97 lies directly below terraces 103 and 104, and terrace 98 is located slightly above and to the east of T97.

T97 is semi-circular in shape, and measures about 25 meters long by 5 meters wide at its widest point, with an approximate surface area of 101 meters. We estimate T97 to consist of about $118 \mathrm{~m}^{3}$ of rock and sediment. Bedrock is exposed on the lower talus slope, and there are several support walls immediately below the main terrace wall. Large rocks are distributed uniformly across the terrace surface.

Lithics were common on the surface of T97, including several cores and bifaces, numerous flakes, and one hammerstone. The ground stone distribution was

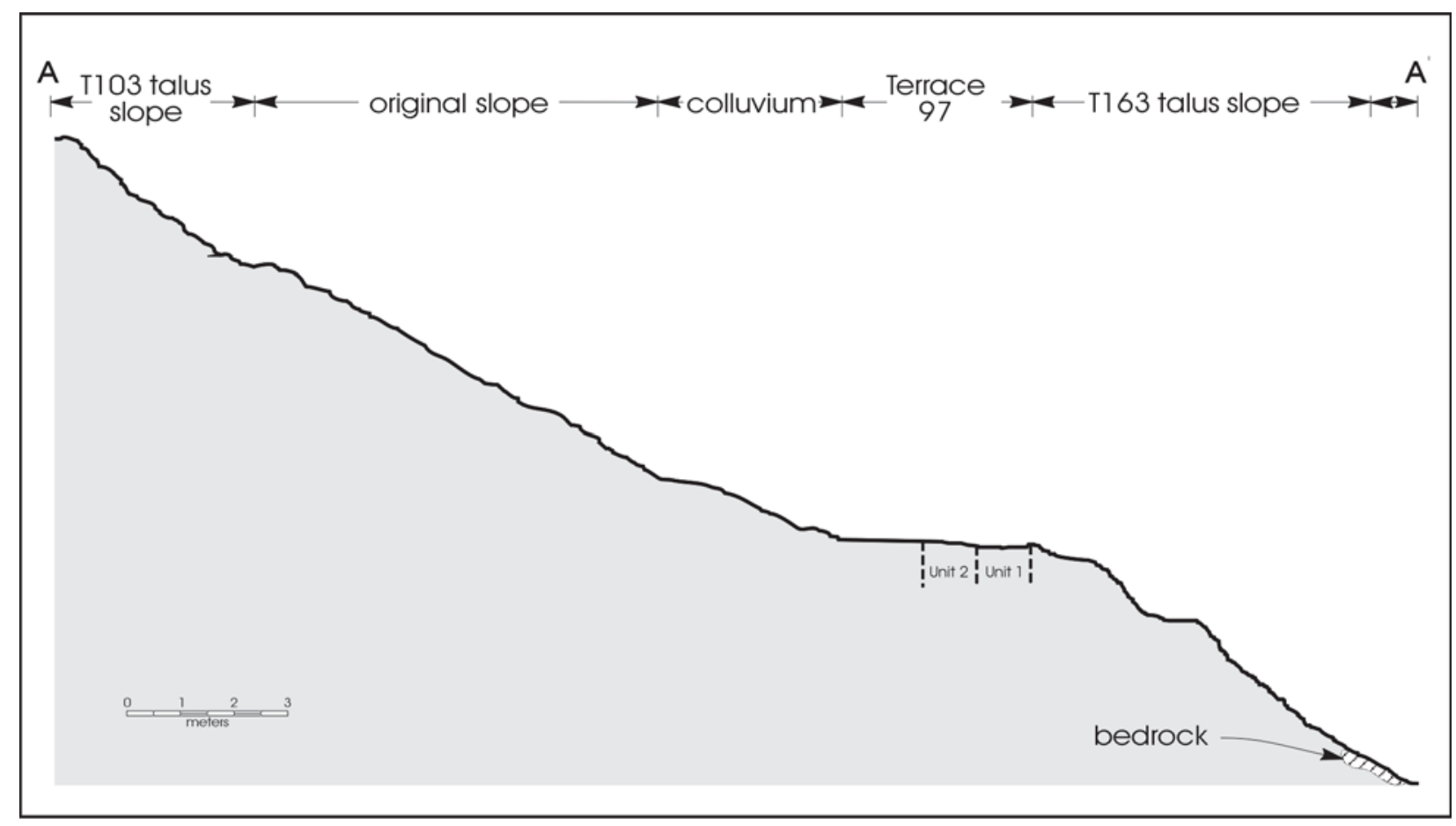

Figure 14. Cross-section of T97 
sparse, with one mano fragment found on the terrace surface, and two mano fragments and a basin metate fragment noted on the lower talus slope. T97 was selected for excavation in order to obtain datable materials from the south side of the site, and because the terrace deposits appeared to be relatively deep. Also, ants on the terrace were bringing large amounts of lithic debris and small bone fragments to surface.

\section{Excavation strategy}

After T97 was mapped and all surface artifacts recorded, two excavation units were placed near the midline of the terrace, adjacent to the berm wall. Unit 1 was layed out at the terrace edge, and Unit 2 was placed immediately to the north of Unit 1 . Units 1 and 2 were excavated simultaneously, to maintain consistency in the plan view maps for each level. Bedrock was encountered at about 80 below the surface in Unit 2, and it gently sloped to the south down to about $100 \mathrm{~cm}$ below the surface in Unit 1. Excavation activities ceased when bedrock was completely exposed in both units.

\section{Stratigraphy}

We identified five stratigraphic zones in the west profile of Units 1 and 2; from the bottom up they are: Zones 0, 1, 2, 3, and 4 (Figure 15). Zone 0 is a $5 \mathrm{~cm}$ layer of carbonate-encrusted gravels within a compacted matrix that sits on top of bedrock. We believe Zone 0 to represent the original ground surface on which T97 was built, as Zone 1 lies on top of it in Unit 1 . Zone 1 is the terrace wall, and is dominated by small, medium, and large rocks within a 10YR5/3 sandy loam matrix. Zone 1 does not extend into Unit 2. Overlying Zone 0 in Unit 2 is Zone 2, which is the terrace fill of T97. Zone 2 is a 10 YR5/3 sandy loam with relatively few small and medium rocks evenly

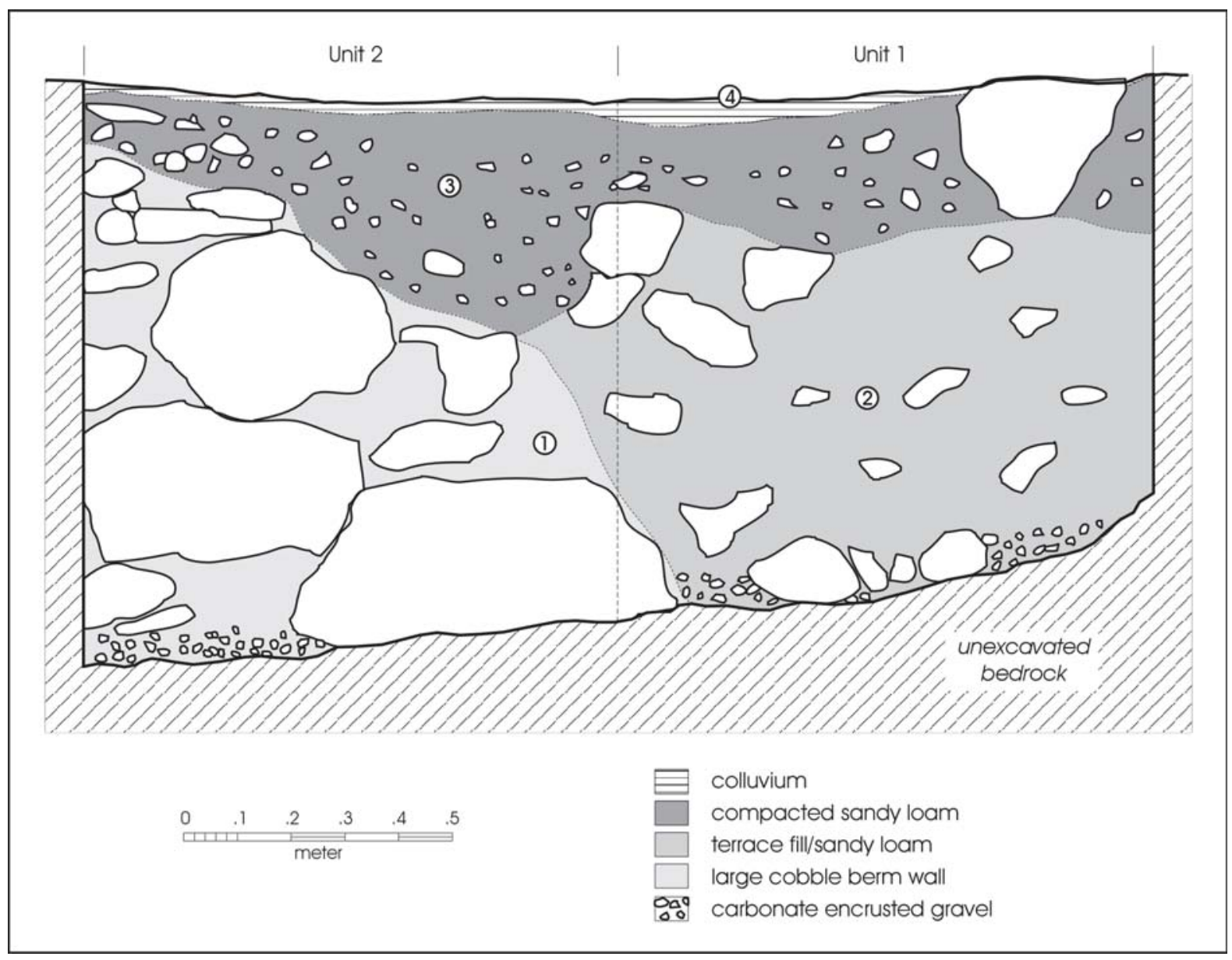

Figure 15. Unit 1 and 2 profile, T97. 
distributed throughout. Both Zones 1 and 2 average about $60 \mathrm{~cm}$ thick.

Zone 3 overlies Zones 1 and 2 in both units. It is a compacted layer of $10 \mathrm{YR} 4 / 3$ sandy loam with smaller rocks and gravels mixed in. We believe Zone 3 to represent the prepared occupation surface of T97. On top of Zone 3 is Zone 4, a $5 \mathrm{~cm}$ thick layer of sandy colluvium on the modern surface of the terrace.

\section{Artifacts}

Although the number of cultural materials recovered from T97 is small, the majority of them are lithics and bone. They appear to be relatively evenly dispersed throughout all levels. Several pieces of shell were collected from Unit 2, Level 1, as well as one San Pedro projectile point. An undiagnostic point fragment from the same level was found in the screen. Two charred Zea mays cupules, one cob fragment, one cob segment, and a cheno-am seed were collected from Level 7 of Unit 1, and three charred Zea mays cupules and a Ferocactus seed were recovered from Unit 1, Level 8. The cob fragment from Level 7 has been submitted for radiocarbon dating.

\section{Interpretation}

As with other terraces on Cerro Juanaqueña, it appears that T97 was constructed using a natural shelf formed by bedrock. We believe that Zone 0 , a thin $(5 \mathrm{~cm})$, compact layer high in calcium carbonate directly on top of bedrock, represents the original ground surface on which T97 was built. A large berm wall of rock was built on the outer edge of the shelf, and then a fill consisting of sediment and smaller cobbles was dumped behind this berm to form a level occupation surface. We believe Zone 3 to represent the prepared occupation surface of T97, as it is more compacted than the other layers. The cultural debris recovered during excavation most likely filtered down from the occupation surface into the terrace fill through the activities of roots, small animals, erosion, and gravity.

\section{Terrace 126}

\section{Description}

Terrace 126 is located on the southeastern slope of Cerro Juanaqueña, about 19 meters below the summit of the hill. It is adjacent to Terraces 125 (to the west), and 127 (to the east). Terraces 125, 126, and 127 are well defined, as they are separated by distinct rock alignments. Terraces 113 and 114 are located directly downslope from T126, and T137 lies up slope. T126 is approximately 8.5 meters long and 7 meters wide at its widest point, and its surface area is about $44.2 \mathrm{~m}^{2}$. We estimate T126 to contain about $41.25 \mathrm{~m}^{3}$ of rock and sediment. The terrace surface slopes gently down to the south, and bedrock outcroppings are exposed at the surface level along the northern portion of the terrace. The outer berm wall on this terrace appears to have been subject to a great deal of erosion, as the outer edge of the terrace is slumped.

No significant artifacts were present on the surface of T126, save an obsidian flake to the north of Unit 2, and a few core fragments scattered on the terrace surface and along the lower slope. Also, a projectile point (surface item \#340) was collected from the terrace surface, just south of the exposed bedrock. T126 was selected for testing because at the time no dates were available for the southern side of the site, and because the terrace was estimated to contain approximately one meter of fill.

\section{Excavation Strategy}

T126 was first mapped and all significant surface artifacts were recorded and collected. We then laid out two adjacent, one meter by one meter units at the southern edge of the terrace, perpendicular to the berm wall, in a north to south direction. The units were placed in this position in order to define the terrace wall construction. Unit 1 was located at the terrace edge, and Unit 2 was placed immediately to the north of Unit 1. Both units were excavated simultaneously in $10 \mathrm{~cm}$ levels. At Level 2 in Unit 2 we encountered a hard packed surface, which we pedastalled and gave a subfeature designation ("Hard Packed Surface A"). 
This area was well-documented in the notes and plan views. After further exploration, we determined that "Hard Packed Surface A" was a natural feature, and thereafter it was excavated in $10 \mathrm{~cm}$ levels.

Bedrock was first encountered in Unit 2, Level 10, at about $85 \mathrm{~cm}$ below the terrace surface. The bedrock sloped gently down to the south, until it reached its lowest point at about 1 meter below the surface at the south wall of Unit 1. Excavations on T126 ceased when bedrock was completely exposed in both units.

\section{Stratigraphy}

Five stratigraphic zones were identified in the east profile of Units 1 and 2 on T126. The lowermost,Zone 1 , lies immediately above bedrock in Unit 1 , and does not extend into Unit 2. This zone is about $20 \mathrm{~cm}$ thick, and consists of a 10YR3/2 silty loam with a very "powder-like" consistency, and numerous gravels. Near the bedrock, there is a large amount of calcium carbonate deposits mixed in with the matrix. Larger rocks are relatively scarce in this zone. Zone 2 lies immediately above Zone 1, and consists of the wall fill of T126. Zone 2 averages about $90 \mathrm{~cm}$ thick, and extends from the surface down to Zone 1 in Unit 1. Zone 2 represents only the southern $15 \%$ of Unit 2 . This zone consists mainly of large $(20-25 \mathrm{~cm})$ basalt cobbles, with some smaller rocks $(<15 \mathrm{~cm})$ and gravels mixed in. The matrix is a 10YR3/2 silty loam. There was a peak in artifact densities near the bottom of Zone 2. Zone 3 borders Zone 1 in Unit 2, but does not overlie it, as Zone 3 lies directly on top of bedrock. This zone, which averages about $50 \mathrm{~cm}$ thick, is a dark gray brown (10YR4/2) silty loam that is dominated by smaller rocks and gravels. There are numerous $\mathrm{CaCO} 3$ deposits toward the bottom of Zone 3, especially immediately above bedrock. Zone 4 lies on top of Zone 3. It averages about $30 \mathrm{~cm}$ thick, and consists of small to medium rocks, which make up about $80 \%$ of the zone. The matrix of Zone 4 is a dark grey brown (10YR4/2) sandy silt. This zone is somewhat compacted, and we believe this to be the original occupation surface. This surface is about $15 \mathrm{~cm}$ below the modern surface. Zone 5 lies on top of Zone 4, and averages about $15 \mathrm{~cm}$ thick. The zone consists of a 10YR4/2 silty sand, dominated by small rocks. Some root disturbance is present.
Overlying Stratum 5 is the modern surface, a $3 \mathrm{~cm}$ thick layer of sandy loam.

\section{Artifacts}

As noted earlier, one obsidian flake and one projectile point (\#340) were found on the terrace surface prior to excavation. Materials collected from T126 during excavation include lithics (primarily rhyolite and chalcedony, with a few obsidian flakes as well), faunal remains (including cottontail, a great deal of jackrabbit, snake, rodent, and a fish vertebrae), carbon samples (both charcoal and maize), and one small piece of shell. The majority of artifacts were recovered from the lower levels of excavation. There was a peak in artifact densities in Unit 1, Level 9 (about 90 $\mathrm{cm}$ below the surface), from which we recovered 70 lithics (five of which were obsidian flakes), 419 bone fragments, and a substantial amount of charcoal.

The only maize noted during excavation came from Unit 1, Level 10, 260-278 centimeters below datum. However, flotation samples provided many more maize fragments, including numerous cupules and 2 kernel fragments, and one charred cheno-am seed, also from the deeper levels of excavation. Zea mays cupules from Unit 1, Level 9 have been submitted for radiocarbon dating.

\section{Interpretation}

The presence of exposed bedrock on the terrace surface and the gentle slope of the bedrock noted during the excavation of Units 1 and 2 suggest that the inhabitants of Cerro Juanaqueña constructed T126 by building a tall berm of large rocks on the edge of a naturally formed shelf. A relatively deep layer of sediment, gravels, and cobbles was then dumped behind this wall to provide a level occupation surface. No prepared living surface was encountered during the excavation of T126. However, while profiling, a relatively level compacted layer was identified as the possible occupation surface. Over time, colluvial and eolian processes buried this occupation surface under about $15 \mathrm{~cm}$ of sediment. 
The presence of most of the cultural materials in the deepest excavation levels implies that a great deal of downward vertical movement has taken place in the deposits of T126. It appears that cultural materials have filtered down through the open spaces in the terrace fill. Insect, rodent, and root disturbance probably contributed to this process.

\section{Terrace 163}

\section{Description}

Terrace 163 (T163) measures 16 meters wide by 9 meters and is located on the southeast quadrant of the hill (Figures 16 and 17). The length of the terrace wall is $15 \mathrm{~m}$, and the surface area of this terrace is approximately $33 \mathrm{~m}^{2}$. The terrace is constructed of an estimated $68 \mathrm{~m}^{3}$ of sediment and rock. The depth of the berm wall to bedrock is about 66 centimeters. The berm wall is almost rectangular in shape (north to south), except for the north half of the talus, which is oriented to the northwest at a 45 degree angle. The terrace surface was fairly level and bedrock outcrops were noted at the far west end of the terrace surface. A rock concentration was located about $.5 \mathrm{~m}$ to the northwest of Unit 2, and another about $3 \mathrm{~m}$ to the north of Unit 1. Located in the vicinity of T163 were T164 to the north, T171 upslope to the west, and T162 located to the south. A wall-like feature is located about $1 \mathrm{~m}$ to the south of Units 1 and 2, and extends $5 \mathrm{~m}$ downhill to the southeast. This wall-like feature and the T163 berm wall are separated by a well-worn path. This feature is one of the few walls that extend downslope, as opposed to across the slope, on the site.

Terrace 163 was selected for testing based on its location on the southeast side of the hillslope and the need for testing in this quadrant of the site. Also, the decision to test this feature was based on its location along the south end of the $400 \mathrm{~m}$ long macro-feature, and its apparent depth, which suggested we might locate better preserved botanical specimens.

\section{Excavation strategy}

Two 1 by 1 meter units were located side by side and perpendicular to and about $1 \mathrm{~m}$ back from the terrace wall, and oriented east to west. Initially, both units were excavated in $10 \mathrm{~cm}$ levels, but this strategy changed when several compacted surfaces were located. Unit 1 was excavated to a final depth of $66 \mathrm{~cm}$ below surface, and Unit 2 was excavated to $64 \mathrm{~cm}$ below surface.

Unit 1, Level 1 was excavated down to a compacted surface, designated Surface B, which was also located and similarly designated in Unit 2. Excavation of Unit 1, Level 2 proceeded past a second surface, designated Surface C, which was located in Unit 2, Level 2. A third surface, designated Surface A, was located $3 \mathrm{~cm}$ beneath Surface C. An arbitrary level of $10 \mathrm{~cm}$ was then excavated, and when excavation proceeded to the next level, a fourth surface was located, designated Surface D. The remaining levels, Levels 6, 7, and 8, in Unit 1, and Levels 7 and 8 in Unit 2 were excavated in arbitrary $10 \mathrm{~cm}$ levels.

\section{Stratigraphy}

The lower-most zone was comprised of a very dark, grayish brown (10YR3/2) loam with $3 \mathrm{~cm}$ to $25 \mathrm{~cm}$ size rocks (Figure 18). This zone was between 30 and $46 \mathrm{~cm}$ thick and materialized rather abruptly at about $20 \mathrm{~cm}$ below surface. Owing to ash content, rock size and density, this zone was subdivided into two zones: Zone 1a, the lower-most zone, is resting on bedrock and consisted of a dark loam with an abundance of ash and a heavy concentration of medium to largesize rocks. In contrast, Zone $1 \mathrm{~b}$ had less ash and a lighter concentration of smaller rocks, most of which were fist-size. The upper limit of Zone $1 b$ was Surface D, which was distinctly dark, compact, and smooth. Zone 2 was about $8 \mathrm{~cm}$ thick and consisted of a dark brown (10YR3/3) silty loam with a slightly lower ash content than Zone 1, and very few rocks. Zone 3, about $7 \mathrm{~cm}$ thick, consisted of a brown (10YR4/3) loam that lacked a significant amount of rocks. The upper limit of Zone 3 included Surface A and Surface C, both of which appear to originate from laminated colluvial deposits. The uppermost zone is 


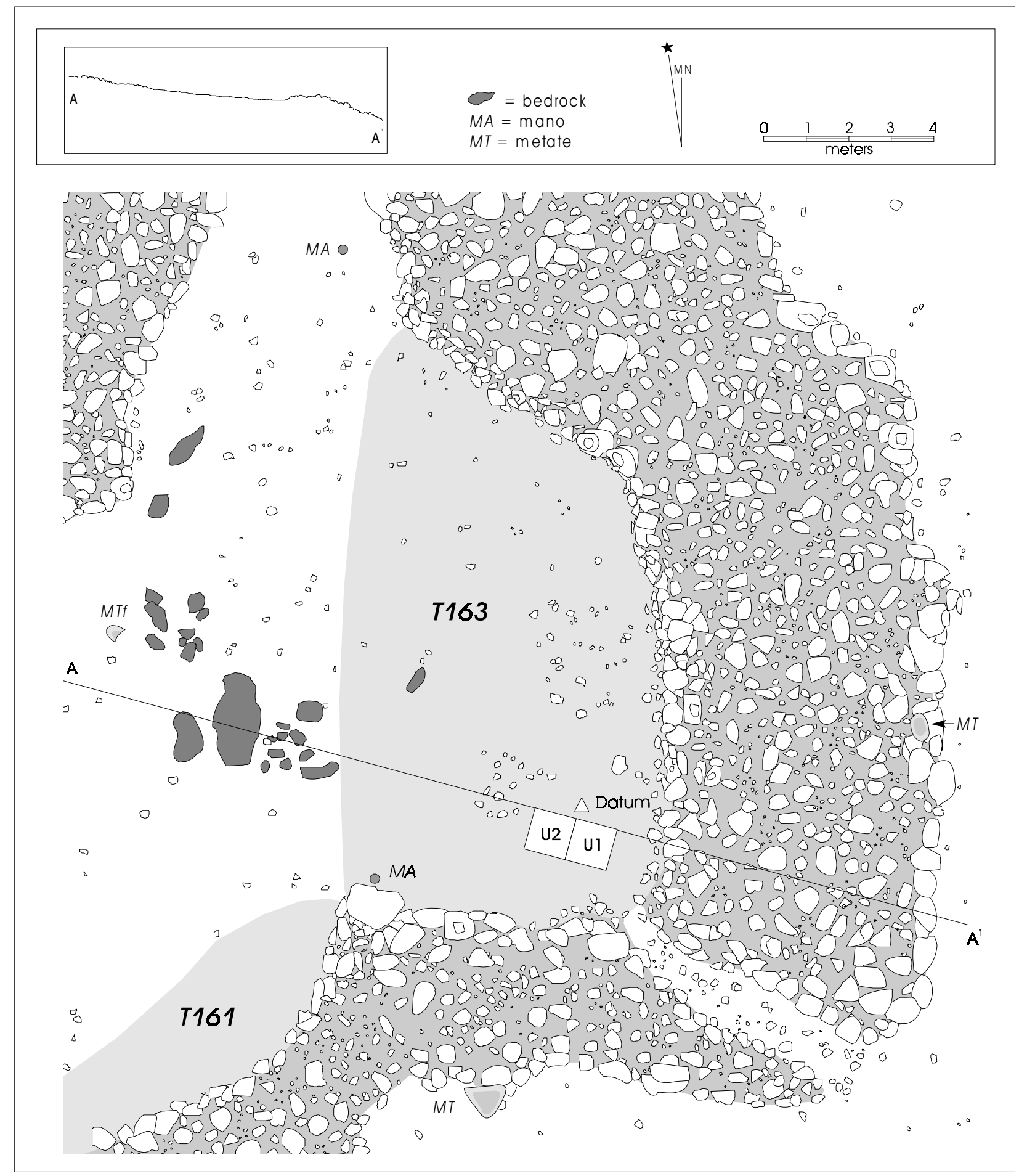

Figure 16. Plan view of T163.

divided into Zone $4 \mathrm{~b}$ and Zone $4 \mathrm{a}$. It was about $4 \mathrm{~cm}$ thick and comprised of a brown (10YR4/3) silty, powdery loam with very few pebbles and rocks. This zone includes Surface B and it also appears as a laminated colluvial deposit. 


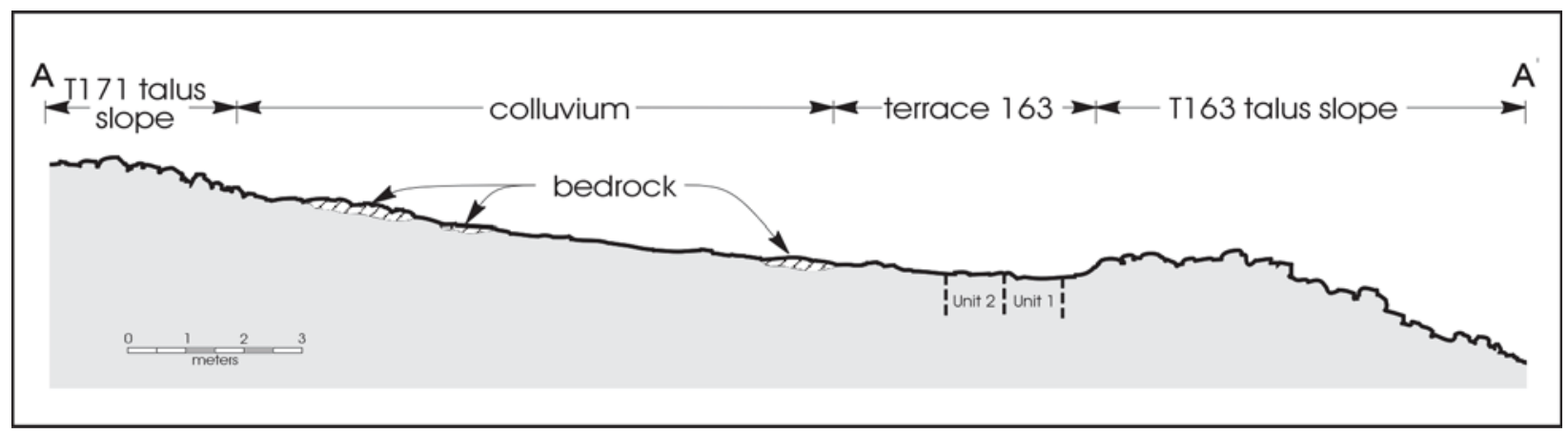

Figure 17. Cross-section of T163

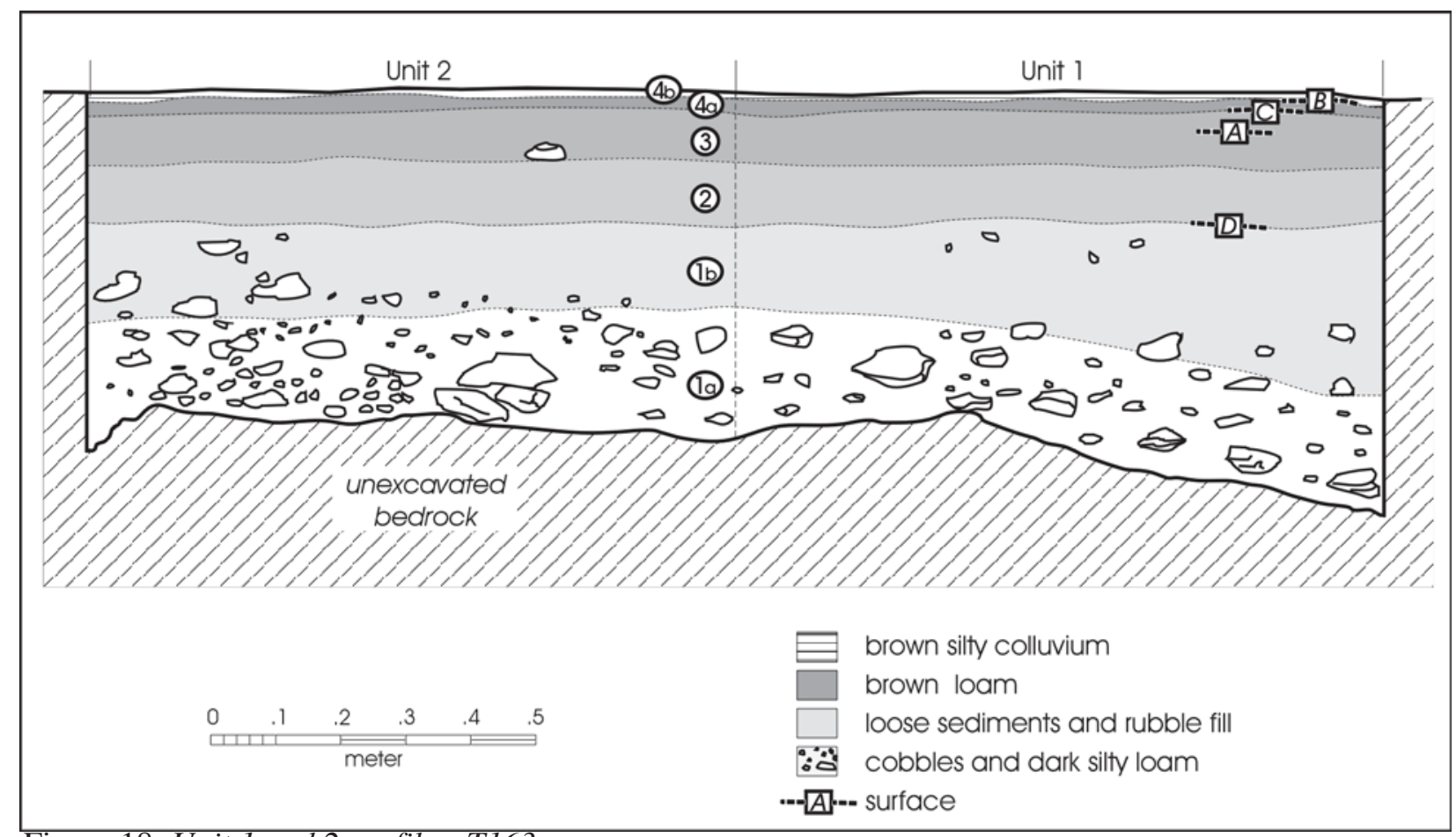

Figure 18. Unit 1 and 2 profiles, T163.

\section{Artifacts}

Artifact densities among zones were fairly consistent, in terms of the amount of lithic material recovered from Zones 4, 3 and 2 (0-20 cm below surface) and Zones $1 \mathrm{a}$ and $1 \mathrm{~b}$ (20-66 cm below surface). In contrast, the occurrence of bone was higher in Zones 1a and $1 \mathrm{~b}$ (approximately 350 bone fragments) as opposed to about 280 in Zones 2 and 3. Charcoal was recovered from Unit 1, Levels 3, 5, 6, 7, and 8, and from Unit 2, Levels 6, 7, and 8. Projectile points were recovered from Unit 2, Level 6, and maize from Unit 2 , Level 8. The Zea mays specimens (2 cob fragments) were submitted for radiocarbon dating. The recovery of other macrobotanical specimens was moderately successful. Twenty-two specimens were recovered from the flotation samples, and all were from within the last $20-30 \mathrm{~cm}$ of fill. Fifteen specimens were recovered from Unit 1 (7 Cheno-am seeds, 7 Zea mays cupules, and 1 Salvia); and 7 specimens from Unit 2 (2 Cheno-am seeds, 2 Prosopis charcoal, 2 Zea mays cob fragments, and 1 cupule). 


\section{Interpretation}

The stratigraphic profile of this terrace presented a well-defined terrace construction sequence. Although not excavated, but owing to the absence of colluvial sediments below Zone 1a, it seems likely that the 1 $\mathrm{m}$ high berm wall was laid onto exposed bedrock. The height of the berm wall is based on the $66 \mathrm{~cm}$ depth of Unit 1, and an estimated $35 \mathrm{~cm}$ of berm construction exposed above surface. Zone 1a represents the rock fill added behind the berm wall, which was comprised of medium to large-size rocks. An additional layer, Zone $1 \mathrm{~b}$, of smaller rocks and sediments was then laid to create a level living surface. The upper limit of Zone $1 \mathrm{~b}$ was clearly marked by Surface D, a compacted, moderately undulating occupation surface. The lack of weathering and pitting suggests Surface D may have been roofed, which is consistent with a compact, well-preserved surface with few artifacts resting on it. The higher densities in ash, charcoal, and bone material recovered below Surface D is also consistent with the downward movement of artifacts, especially lithic material, through rocky deposits. After abandonment, the original living surface, Surface D, was overlain by 3 laminated colluvial deposits. The first deposit was designated Surface A, which was then capped by Surface $C$ and then by Surface B. Artifacts recovered from within these colluvial sediments can be attributed to redeposited material from upslope terraces.

\section{Terrace 234/Ring 234a}

\section{Feature Description}

Terrace 234 (T234) lies approximately 11.5 meters below the summit of Cerro Juanaqueña along the northwestern face and was tested by the placement of a shovel test and 2 excavation units. The wall of this oblate terrace stretches approximately 48.6 meters north/south. The berm walls are unusually well preserved at the northern end of this feature and some stacking of cobbles appears to be present. Terrace widths vary between 2 and 3.5 meters and the total surface area is $248 \mathrm{~m}^{2}$. The total volume of material used to construct T234 is estimated at $218.6 \mathrm{~m}^{3}$, which is quite large.

Numerous artifacts were recorded on the terrace surface and talus slope of T234 including a projectile points (\#379), a partial bone awl (\#378), a biface (\#380), two spherical manos, several mano fragments, a basin metate, and a hammerstone. A shovel test was placed at the northern end of the terrace where the bone awl was recovered and adjacent to an area of bioturbated soils. One additional piece of altered bone, possibly the tip of a second bone awl, as well as other burned bone fragments and lithic debitage were recovered from this shovel test.

An associated feature, Ring 234a (R234a), is located approximately $4 \mathrm{~m}$ north of the shovel test and appears to have been built concurrently with construction of T234. The outline of R234a is discernible as a broken circle (3.75 diameter) of basalt cobbles embedded into the colluvium of the modern surface. Artifacts directly associated with this subfeature include several metate fragments, a spherical mano, a hammerstone and several pieces of lithic debitage. Because investigation of rock rings has thus far been limited to the testing of three similar features during the 1997 season, it was decided that R234a would become the focus of excavations on this terrace.

\section{Excavation Strategy}

Initially, all surface artifacts on T234 were recorded and mapped. A shovel test was placed in the northern portion of T234 in the area where the bone awl and several pieces of charred bone were observed. After the shovel test produced additional carbonized materials, it was decided that two units would be laid out in the nearby feature, R234a. We selected R234a in the hopes of gaining insight into the function of the rock rings. Units 1 and 2 were placed inside the rock ring near the front (western) edge in an area expected to represent a moderately deep fill. These units were excavated simultaneously in $10 \mathrm{~cm}$ levels and were closed only after bedrock had been exposed in both units. Bedrock extended down to a maximum depth of $85 \mathrm{~cm}$ below the surface in the western portions of Unit 1. 


\section{Stratigraphy}

Five stratigraphic zones were identified in the south profile of Units 1 and 2 on R234a. Although an uppermost, overlying lense of colluvium wasn't recorded in the profile, it is possible that this zone was too thin and broken to be apparent. Zone 5 is the lowest identified stratum of both units and appears to be a deep, loose matrix of clay loam intermixed with medium size $(4-10 \mathrm{~cm})$ cobbles laid directly on bedrock. This zone appears to represent the major portion of construction fill associated with this feature. This material is deepest at the eastern and western edges of the units and forms a hollowed out "bowl" shape in the middle. The zone averages $35 \mathrm{~cm}$ thick, and consists of a 10YR3.5/2 clay loam supported by small cobbles and gravels. Zone 4 immediately overlies Zone 5 and forms a thin layer $(\approx 13 \mathrm{~cm})$ of non-calcareous loam which appears to have been deposited horizontally within the "bowl". Zone 3 overlies Zone 4 and is distinguished by a slight change of color from a very dark grayish brown (10YR 3.5/2) toward a dark grayish brown (10YR 4/2). Zone 2 also appears to have been deposited horizontally and consists of a silty clay loam with $\approx 5 \%$ gravel inclusions. This zone is a dark brown 10YR 4/2.5 with a blocky structure and averages 7 $\mathrm{cm}$ thick near the center of the two units. Finally, Zone 1 represents the uppermost stratum and includes the modern surface. Zone 1 is composed of a thin veneer $(\approx 3 \mathrm{~cm})$ of fluvial material interspersed with pebbles and is distinguished from Zone 2 by its platy structure. This stratum is composed of a dark brown 10YR $4.5 / 3$ fine silty clay.

\section{Samples and Artifacts}

Numerous float samples were taken from Units 1 and 2 in the hopes of obtaining datable material for R234a. Unfortunately, as with other rock rings tested at Cerro Juanaqueña, no botanical or carbonized material were recovered. Lithic debitage was also very sparse; the upper $30 \mathrm{~cm}$. yielded the largest quantity before dropping off dramatically in the lower levels. The only formal tools recovered were collected from the surface of R234a.

\section{Interpretation}

Because habitation is considered a possible function of rock rings, careful attention was paid to the uppermost deposits to determine whether subfeatures such as occupational surfaces or hearths were present. However, no indication of an occupational surface was encountered.

It appears that R234a was constructed by the piling of large cobbles directly upon the underlying bedrock and associated colluvium, creating a bowl-shaped depression. Subsurface testing also suggests that the large cobbles were piled in to create the ring and no formal stacking was discernible. However, it is also possible that at least part of this depression could have been created by wall fall. The stratigraphy seen in the south wall profile of Units 1 and 2 indicate that the rock ring extends well into the sub-surface and was not just an ephemeral construction on the living surface. However, the exact sequence of events relating to the building of the ring within the overall construction sequence of T234 could not be ascertained during our limited investigations.

\section{Terrace 273}

\section{Description}

Terrace 273 is located on the northwest slope of Cerro Juanaqueña, about 5 meters below the summit. It is just above T275 and T276, and between T272 (to the south), and T66 (to the north), and faces west. T273 is semicircular in shape, has a surface area of about $96 \mathrm{~m}^{2}$, and is about 18 meters long and 6 meters wide at its widest point. The southern boundary (between $\mathrm{T} 272$ and T273) is distinct, and is formed by a rock wall approximately one meter high. The northern boundary (between T273 and T66) is less obvious, and is marked by a subtle scatter of smaller cobbles. No subfeatures were noted either on the surface of T273 or during subsurface excavation.

T273 was selected for excavation because it was necessary to obtain datable material from the north and northwest parts of the site, and because we observed 
ants on the terrace bringing a large amount of lithic debris and small bone fragments to the surface. We placed one shovel test pit near the center of the terrace. Although from the surface the terrace had appeared to have deeper deposits, the shovel test reached bedrock at only $10 \mathrm{~cm}$. However, there was enough lithic and bone material present in the test pit to warrant further excavation.

\section{Excavation strategy}

First, T273 was mapped and all surface artifacts were recorded. Then we set out two adjacent, one meter by one meter units on the southern end of T273, in a generally southwest to northeast direction. Both units were excavated simultaneously in $10 \mathrm{~cm}$ levels, and excavations ceased when bedrock was exposed. Bedrock was exposed at $17 \mathrm{~cm}$ below the surface in the northwest, and it sloped down to about $60 \mathrm{~cm}$ below the surface in the southeast.

\section{Stratigraphy}

We identified three stratigraphic zones in the north profile of Units 1 and 2. Immediately above bedrock lies a layer of wall fill (Zone 3 ) that consists of sediments with rocks of various sizes mixed in. The matrix is a granular, light brown (10YR4/2.5) silty loam, with numerous rock inclusions. Rocks within the matrix range from small gravels to medium cobbles, but mostly consist of large boulders, which are part of the wall feature of T273. Near the bedrock, there is a large amount of calcium carbonate deposits in the matrix. Evidence of small-scale disturbance is present throughout both units, and is represented by the presence of small roots and insects, such as ants, termites, and beetles.

Zone 2 lies on top of Zone 3, and consists of a 3-8 cm thick layer of dark grayish brown, loose granular silty loam, with numerous gravels. On top of Zone 2, at the surface, lies Zone 1, which is a very thin $(2 \mathrm{~cm})$ layer of brown (10YR5/3) eolian silty loess.

\section{Artifacts}

Prior to 1998, three items were collected from the surface of this T273: a projectile point tip (surface collection \#97), a biface (\#275), and a biface midsection (\#98). In 1998, four projectile points were recovered from this terrace: one on the terrace surface (\#371), one in Level 1 of Unit 1, one in Level 2 of Unit 1, and one on the talus slope below T273 (\#370). Seven metates are scattered across the terrace surface and the talus slopes above and below T273, and several groundstone fragments were collected from Units 1 and 2, Level 1. Lithic materials and animal bone fragments were recovered from all excavation levels, but were most abundant in Level 1, where at least 100 lithics and 50 bone fragments were recovered from each unit. The artifact densities steadily decreased as we approached bedrock. The only macrobotanical sample recovered from T273 was a small fragment of charcoal from Unit 1, Level 2. This is probably due to the shallow depth of the deposits on T273, which may have adversely affected the preservation of the macrobotanical remains.

\section{Interpretation}

The shallow depth of the bedrock at such a close proximity to the terrace edge suggests that T273 was constructed by building a berm of large rocks on the outside edge of a natural shelf formed by the bedrock of the cerro. To complete the terrace, a shallow layer of terrace fill, consisting of small cobbles, gravels, and sediment, was then piled up behind this berm. The wall fill is visible in the north profile of the excavation, and the terrace fill is visible in the south profile, because the excavation units were laid out at the terrace edge roughly parallel to the berm wall. No apparent prepared occupation surface was noted during the excavation of T273. The presence of cultural materials in the subsurface levels can be explained in several ways. One possible explanation is that cultural debris has filtered down from the occupation surface through natural processes, such as insect, rodent, and root disturbance. The presence of insects noted during excavation supports this notion. 


\section{Terrace 290}

\section{Description}

Terrace 290 (T290) is a large terrace located on the southwest side of the hillslope. The terrace is 28 meters wide by 16 meters long, with the talus extending down to Terrace 293. The surface area is approximately 61 $\mathrm{m}^{2}$, and the length of the terrace wall is 19 meters. The terrace was constructed of an estimated $87 \mathrm{~m}^{3}$ of sediment and rock, and is a maximum of $95 \mathrm{~cm}$ deep, measured from the top of the berm wall to bedrock. In proximity to T290 are T287 to the northeast and T294 to the south. The T290 talus appears to have been dispersed and forms an eroded area between T293 and T294. The surface of T290 is cobble-covered and appears to relate to the erosion, and these are consistently large $(>25 \mathrm{~cm})$. The surface artifacts number about 50, with approximately 20 being comprised of manos, metates, and hammerstones.

Terrace 290 was selected for testing primarily because it appeared to be at least 1 meter deep and in view of the high density of surface artifacts. Additionally, ashy deposits were found on the surface of the terrace which suggested the presence of charred plant material.

\section{Excavation strategy}

Two units, designated Unit 1 and Unit 2, were excavated. Both units were 1 by 1 meter units, and each was excavated to bedrock. Unit 1 was deeper and was excavated to a depth of $70 \mathrm{~cm}$ below surface (100 to $170 \mathrm{~cm}$ below datum) and Unit 2 was excavated to 61 $\mathrm{cm}$ below surface (96 to $157 \mathrm{~cm}$ below datum). The units were located so that Unit 1 encompassed the ashy surface stains, with Unit 2 adjoining Unit 1 to the north. The placement and excavation of this units also permitted a view of the wall construction and its relationship to bedrock.

\section{Stratigraphy}

The terrace stratigraphy appears uncomplicated, consisting of 3 distinct depositional events. The lowermost zone, Zone 1, was a fine, loose, gravelly loam. The sediment was a brown (10YR4.5/3) even mixture of sand, silt, and clay. The difference in soil color between Zone 1 and Zone 2 was almost unnoticeable, but these zones were contrasted by the lack of cobbles and more pebbles in Zone 2. The sediment in Zone 2 consisted of a dark brown (10YR5/3) fine, silty loam with gravels. Zone 3 consisted of a thin layer $(<4 \mathrm{~cm})$ of brown (10YR5/3) colluvium or topsoil. Overall the sediments in each of the three zones were comparable and seem to reflect similar depositional events.

\section{Artifacts}

The artifacts recovered from Units 1 and 2 were typical of those found at Cerro Juanaqueña. Bone, lithic material, shell, and a complete mano were recovered. Artifact densities were low but seemed to be highest in the upper levels. Most of the bone was not well-preserved. The few fragments that were identifiable, were that of jackrabbit. The only charred macrobotanical specimens recovered from flotation were 4 Zea mays cupules from Unit 1, Level 5. Some of these specimens were submitted for radiocarbon dating.

\section{Interpretation}

The depth of this terrace was shallower than expected, extending to between 60 and $70 \mathrm{~cm}$ below surface. The terrace was constructed by leveling the natural surface with Zone 1, a $40 \mathrm{~cm}$ thick layer of sediment and medium to large-size rocks. A definite break in gravels and rock size was noted between Zone 1 and Zone 2. This leads us to suggest that Zone 2 may be attributed to the construction of an activity surface. This zone tapers to about $1 \mathrm{~cm}$ thick at opposite ends, and is thickest $(16 \mathrm{~cm})$ at the center. This forms a noticeable depression which is most likely attributable to the natural settling of the initial fill (Zone 1). After the terrace was abandoned, $2 \mathrm{~cm}$ of colluvial sediments were deposited on its surface, forming Zone 3. 


\section{Feature Description}

T297 is one of the lowermost features of the upper terraces at Cerro Juanaqueña. Facing toward the southwestern, this terrace lies $31.5 \mathrm{~m}$ below the summit of the hill in an area of steep natural slope $\left(>15^{\circ}\right)$. The walls of this oblate terrace stretch approximately 50.6 meters vary from 2.5 to 5 meters wide. The total surface area of T297 is $187 \mathrm{~m}^{2}$ and contains an estimated volume of $27.8 \mathrm{~m}^{3}$ of fill material. T297 was selected because of its central location on the lower western face of the cerro in an area containing a relatively high density of chipped and ground stone artifacts. Upon closer inspection of the terrace surface, ashy soil was observed on the surface near several disturbances at the front of the wall in the northwestern corner of T297. Two excavation units were placed on the terrace surface just above this ashy material, the western edge of Unit 1 being located at the apex of the berm.

\section{Excavation Strategy}

All surface artifacts on T297 were recorded and mapped. Units 1 and 2 were then placed adjacent to one another near in an area of particularly deep construction at the front edge of the terrace at the northern end of the feature. Unit 1 was laid out with its western edge resting on the apex of the berm wall. These units were excavated simultaneously in $10 \mathrm{~cm}$ levels and were closed when bedrock was exposed. Bedrock was first encountered $83 \mathrm{~cm}$ below the surface of Unit 2 and reached a maximum depth of 125 $\mathrm{cm}$ below the surface of Unit.

\section{Stratigraphy}

Five zones were observed in the profile of the southern wall of Units 1 and 2. Zone 1 consists of a thin, broken layer of colluvium and calcified cobbles spread across both units just above bedrock. Directly above this zone in Unit 1 was a thick stratum $(100 \mathrm{~cm})$ of large, unconsolidated cobbles $(>10 \mathrm{~cm})$ embedded within a loose matrix of smaller cobbles $(<5 \mathrm{~cm})$ and silty loam (10YR 3/2). Zone 2 appears to sweep upward to the west and appears to represent the main effort of berm construction on this terrace. Directly behind this zone is an area containing considerably fewer large cobbles and more medium-sized cobbles $(5-10 \mathrm{~cm})$ embedded into a loose matrix of smaller cobbles and silty loam (10YR 3/2). Zone 3 was very hard to distinguish from Zone 2 as large cobbles were common in both units. The only distinguishing characteristic of this zone is the reduction in the number of large cobbles. Zone 4 overlays Zones 2 and 3 and consists almost entirely of small cobbles and fine silty loam (10YR 4/2). Zone 5 represents the movement of colluvial material across the post-occupational surface and is composed of thin lenses $(<3 \mathrm{~cm})$ of dark brown (10YR 4/2) fine silty clay primarily distinguished by their platy structure.

\section{Samples and Artifacts}

Five projectile points, numerous metate fragments, a mano, biface, and cruciform have been recorded and/ or collected from T297. Chipped stone artifacts were recovered from across the terrace surface while most ground stone artifacts were found fragmented and scattered along the downhill slope of the T297 berm wall.

Most of the lithic debitage recovered during excavation came from the top $20 \mathrm{~cm}$ (Zone 5) in the both units. This material appears to be associated with the prehistoric surface and later fluvial episodes which sheet washed debitage across the post-occupational surface. The density of lithic materials drops dramatically around $30 \mathrm{~cm}$ below the surface of both units and only increases again at the lowest levels of the berm fill.

Botanical remains were also recovered from levels 9 and 11 of Unit 1 and levels 7 and 8 of Unit 2 on Terrace 297. These included numerous Zea mays cupule fragments and several charred kernel fragments. A sample of the Zea mays cupules was sent to INSTARR Laboratories at the University of Colorado to undergo radiometric dating.

\section{Interpretation}

Terrace 297 was likely formed in one brief construction sequence. The berm wall seems to have been the 
initial effort of construction with large cobbles being borrowed from the surrounding hillside and tossed into a long arcing ridge which stretches 97 meters around the hill. A second effort included the leveling up of the terrace surface by piling additional cobbles along the back slope of the wall. No real effort appears to have been made to maintain a size specific sorting of material during these two phases aside from the general dominance of large cobbles directly included in the berm wall fill. No occupational surface was discernible either during excavation or in the unit profiles.

Faunal remains mirror the general trend which occurs with lithic debitage excavated from T297. Bones tend to concentrate vertically in two general areas. The first area of higher density appears between 20 and $30 \mathrm{~cm}$ below the modern surface and correspond well with the lithic debitage recovered from the top levels of the units. A second concentration of bone occurs in the lower levels of unit 1 and appears to represent the downward migration of faunal materials within the larger spaces of rock used in wall construction. This mirrors the general pattern seen at other units on Cerro Juanaqueña where artifacts appear to be dispersed evenly across and just below the modern surface and then increases again only in the lower levels nearest the center of the berm wall.

\section{Terrace 387}

\section{Description}

Terrace 387 is in the lower group of terraces on the west side of the site (Figures 19 and 20). It is one of the uppermost terraces among a cluster at the southern end of the site. It is one of five terraces that forms a northwest-southeast alignment approximately $75 \mathrm{~m}$ long. The terrace is separated from Terrace 388 to the southeast by a short protusion of rock and from Terrace 386 to the north by the manner in which the in curving wall of Terrace 387 pinches inward toward the hill. Terrace 387's berm wall is $20 \mathrm{~m}$ long. Up slope, the lower edge of the Terrace 379 forms its eastern boundary. The surface of Terrace 387 is $100 \mathrm{~m}^{2}$ and is $13 \mathrm{~m}$ at its widest point and 18 long. The berm wall was constructed to a maximum height of $1.2 \mathrm{~m}$ above bedrock. The terrace contains about $95 \mathrm{~m}^{3}$ of rock and sediment fill.

Terrace 387 was tested due to the presence of a number of surface artifacts, including flakes, about six core fragments, an obsidian piece, and river cobbles. This was notable as artifacts are rare on the surface of the lower terraces. In addition, the terrace had a clearly defined berm wall that had little evidence of erosion. From surface appearances the fill was at least one meter deep. Finally, a shovel test, excavated in $10 \mathrm{~cm}$ levels into the terrace, was productive and indicated the presence of charred maize, wood charcoal, and significant numbers of artifacts and bone confirming that further testing of this terrace would probably be productive.

The terrace surface was relatively bare of large rocks but gravels were present. Also noted and mapped were three circular or ovoid rock rings, about 1-2 $\mathrm{m}$ in diameter. However these were located in the rock talus slopes; two were down slope and one up slope. It is unknown if these are actually cultural features or natural formations produced as a result of burrowing animals.

\section{Excavation Strategy}

Two adjoining $1 \mathrm{~m}-\mathrm{x}-1 \mathrm{~m}$ units were oriented along the width of the terrace. Unit 1 was placed about $1 \mathrm{~m}$ back from the edge of the terrace with the hope of locating the edge of the berm wall in the profile. The two units were excavated together in $10 \mathrm{~cm}$ levels and their contents were kept separate. Eleven levels were excavated to a depth of $120 \mathrm{~cm}$ below the modern surface.

\section{Stratigraphy}

We identified five stratigraphic zones in the north profile of Units 1 and 2; from the bottom up they are: Zones 4, 3a, 3b, 2, and 1 (Figure 21). The lowermost, Zone 4, rests on bedrock and was present in both Units 1 and 2. It undulates between $20-40 \mathrm{~cm}$ thick and consists of a silty loam with a Munsell color value of 


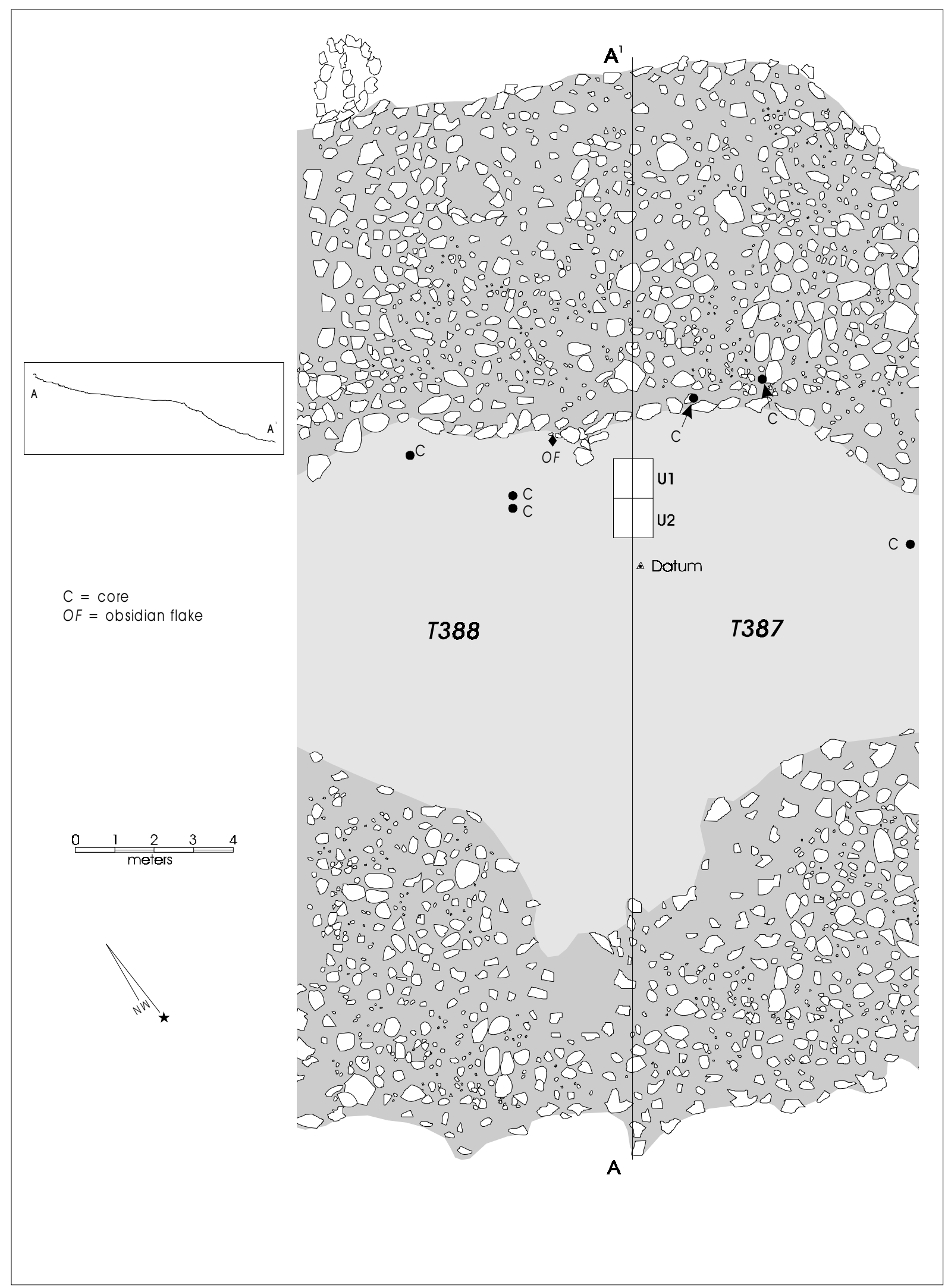

Figure 19. Plan view of T387. 


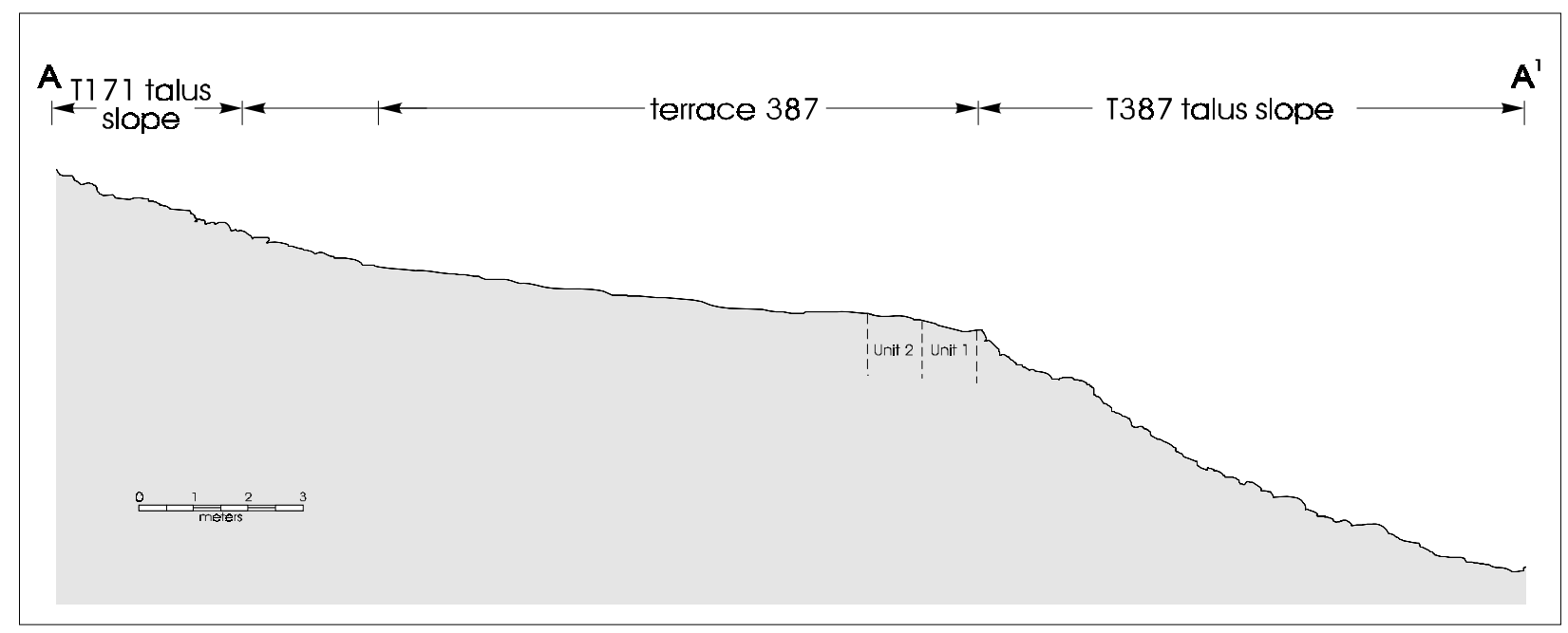

Figure 20. Cross-section of T387.

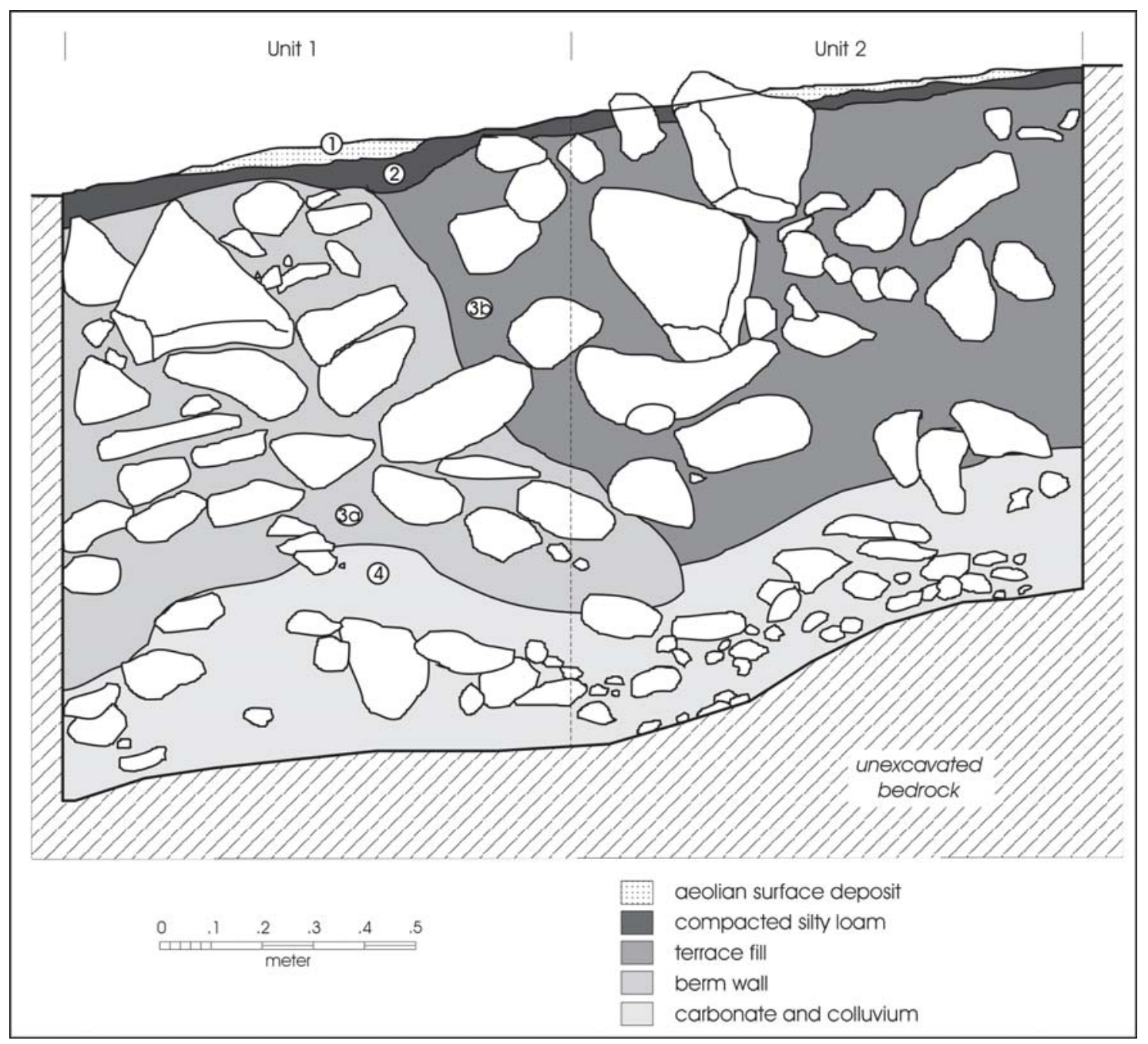

Figure 21. Unit 1 and 2 profiles, T387. 
10YR5/2.5. Calcium carbonate encrusted rocks were common as well as coarse gravels, and weathered rock. This deposit appears to be colluvium and eroded bedrock deposits that were formed by natural processes and lie between bedrock and ancient surface prior to terrace construction. Chipped stone and bone density tapered off substantially in these deposits.

Zone 3 makes up the bulk of the terrace construction fill as it is $70 \mathrm{~cm}$ thick, beginning about $10 \mathrm{~cm}$ below the surface. In the laboratory Zone 3 was subdivided into Zones 3a, the down slope berm wall, and $3 b$, the fill between the wall and the hillside. The nearly vertical boundary between the two is clearly visible as a marked decrease in rock density. Zone $3 \mathrm{a}$ is the rock fill that forms the berm wall and it is only present in the profile of Unit 1. Dense, loose rocks vary in size from $3 \mathrm{~cm}$ to $45 \mathrm{~cm}$ and these are intermixed with a loose grayish-brown (10YR5/2) silty loam with a powder-like consistency. Rock size and density tended to increase downward with no compaction or structure evident. Both lithic and bone counts peak toward the bottom of this deposit with as many as 60 lithics in a $10 \mathrm{~cm}$ level.

Zone $3 \mathrm{~b}$ consists of the fill behind the terrace wall on the western upslope side of the feature. This deposit was present in Unit 2 and the western half of Unit 1. It extends from $5-90 \mathrm{~cm}$ below the surface and contains less rock than Zone 3a. Rocks were common in this unit, although not as dense as in Zone 3a. The sediments were loose and color was similar to Zone $3 \mathrm{a}$.

A slightly compacted surface was detected about 85 $90 \mathrm{~cm}$ below the surface, at the bottom of Zone 3b, resting on the rocks that make-up the top of Zone 4 . This surface is slightly darker, as it is a mottled, pale brown (10YR6/3) and the fill immediately above it had a high quantity of charcoal and ash. Bone and lithic counts increased here, as did bone size. The surface was labeled as "Compacted Surface A". The surface sloped at the same gradient as the natural bedrock and continued into the northern half of Unit 1. This surface was probably the original ground surface on which the terrace was constructed. Rock size and artifact counts dramatically dropped below this surface in Zone 4.
Zone 2 is a thin compacted layer that lies below the thin surface Zone 1 . It is only $5-8 \mathrm{~cm}$ thick and somewhat compacted grayish-brown (10YR5/3), silty loam. It follows the terrace slope but it does not appear to be an occupation surface. In places the rocks in this zone protrude through Zone 1 to erupt on the surface. Artifact counts were low in this zone.

Zone 1 is a the aeolian surface deposit that is $2-5 \mathrm{~cm}$ thick that is present across most of the site. It is a silty loam grayish-brown (10YR5/3) with some small gravels and a platy structure. This zone disappears in part of the profile due to the intrusion of several large rocks.

\section{Artifacts}

One Shumla dart point was collected from Unit 1, Level 5 , about $50 \mathrm{~cm}$ below the surface and a piece of ground stone was found in Level 4. Lithic and bone recovery increased markedly in the lowest $30 \mathrm{~cm}$ of Stratum 3a, the berm wall; and to lesser extent with respect to the bone in lowest $20 \mathrm{~cm}$ in Stratum 3b. Zea mays was the most common taxa recovered and it was present in all levels below level 4. A sample from Unit 1, Level 7 was submitted for radiocarbon dating. Other charred seeds found include: Graminae, Chenoams, and Scirpus. In addition monocotyledon tissue, Prosopis charcoal, and Atriplex charcoal were recovered. Plant recovery was the highest at the bottom of Zone $3 \mathrm{a}$ and $3 \mathrm{~b}$.

\section{Interpretation}

Terrace 387 was constructed on the surface of Cerro Juanaqueña that is now about $90 \mathrm{~cm}$ below the surface. Based on our general knowledge of terrace construction and details from this excavation, it appears that the berm or terrace wall was constructed first by piling large to small rocks $(3-45 \mathrm{~cm})$ to form a berm about $9 \mathrm{~m}$ wide, $18 \mathrm{~m}$ long and about $90 \mathrm{~cm}$ high at its apex. This berm then formed a pocket between the hillslope and the berm that was filled with a mix of rocks and sediment, with more sediment and smaller rocks being used than in the berm. This construction formed the terrace surface, presumably the upper zone or occupation surface was formed by placing a layer 
of dirt on the top to form a smooth occupation surface. However, only a hint of this is evident on the northern end in the upper levels of Unit 2. Although we do not have any house remains the existence of a large amount of domestic debris including lithics, bone, charred plant remains, a projectile point, and ground stone fragment indicate that this terrace was occupied. It is unknown precisely where the occupation surface was, it may have been at the top of Zone 3 or the top of Zone 2. During the occupation event trash has dumped onto the surface of the berm wall. Presumably the trash then filtered downward through the interstices in the rock until its downward movement was halted by the more tightly compacted original ground surface. Here the trash aggregated in its the highest densities. It is unlikely this trash originated by eroding down slope from a terrace above as there is no terrace directly above it in this low cluster. It is also unlikely the trash was deposited on the surface prior to terrace construction as there is a gradually increasing artifact and bone density from top to bottom of the feature. This scenario would require systematic upward movement of substantial quantities of material after the terrace was abandoned. Zone 1 accumulated as a result of aeolian deposition after abandonment.

\section{Terrace 413}

\section{Description}

T413 is in the lower terrace zone on the south-southwestern side of the hill. It is the lowest terrace excavated on Cerro Juanaqueña thus far. T413 is situated among seven small terraces that are all in close proximity, including T409 to the north, T392 to the north/ northeast, T458 to the east, T463 to the southeast, T466 to the immediate south, T423 to the southwest, and T412 to the west. T413 measures about 20 meters long by 8 meters wide, has an approximate surface area of $76.73 \mathrm{~m}^{2}$, and is ovoid in shape. As a result of displacement from above features, small $(<15 \mathrm{~cm})$ rocks are scattered over the surface of the terrace. Surface artifacts were evenly distributed across the terrace surface and talus slope, and consisted of eight river cobbles of various sizes, two cores, an obsidian flake, a pecking stone, a bifacial tool, and a flat, complete mano.

T413 was selected for testing for several reasons. First, it was necessary to obtain datable material from the lower terrace zone in order to establish the temporal relationship between the upper and lower zones. Also, T413 appeared to have a deep terrace deposit and it had an abundant surface artifact assemblage. Ants on the terrace were bringing large amounts of lithic debris and bone to the surface. Finally, a shovel test placed near the central outer edge of the terrace produced abundant charcoal and charred maize fragments.

\section{Excavation strategy}

We set out two adjacent, one meter by one meter units in a generally north to south direction, perpendicular to the terrace wall, about one meter north of the edge of T413. The southern unit was designated Unit 1 , and Unit 2 was immediately to the north. Both units were excavated simultaneously in $10 \mathrm{~cm}$ levels. Bedrock was encountered first in the north wall of Unit 2, at a depth of $115 \mathrm{~cm}$ below the surface. It eventually sloped down to about $140 \mathrm{~cm}$ below the surface in the south wall of Unit 1. Excavation ceased when bedrock was completely exposed in both units.

\section{Stratigraphy}

We identified four stratigraphic zones in the east profile of Units 1 and 2. Zone 4 lies immediately above bedrock. It is a relatively thick $(65 \mathrm{~cm})$ layer of grayish brown (10YR5/2) of loose granular loam matrix, with $79-80 \%$ carbonate-encrusted pebbles and cobbles. Zone 3 lies on top of Zone 4 . It is a $45 \mathrm{~cm}$ thick layer of grayish brown (10YR5/2) loose, granular loam. Small, medium, and large cobbles are mixed throughout, but not as many as in Zone 4 (30-40\%), and $\mathrm{CaCO} 3$ deposits are absent. Zone 2 is a $5 \mathrm{~cm}$ thick, compacted layer that overlies Zone 3. It is a grayish brown (10YR5/2) silty loam with few gravels intermixed. Overlying Zone 2, at the surface, is a thin (2$3 \mathrm{~cm}$ ) layer of light brownish-gray (10YR5.5/2) aeolian silty loess, with some very small gravels. 


\section{Artifacts}

Lithic material and bone was recovered from the majority of the first 8 levels of excavation on T413, but their abundance was much reduced relative to that of most of the other terraces. One ground stone fragment was recovered from Unit 1, Level 1. By far, the most abundant cultural material collected from T413 was charcoal and charred plant remains. Because of the abundance of this material, we took several flotation samples from most levels of excavation in order to obtain as much datable material as possible. The charcoal began turning up in Level 2 of Unit 1, and in Level 1 of Unit 2. A fragment of burned maize cob was recovered from Level 7 of Unit 2, and a possible kernel fragment collected from Unit 1, Level 9. Although virtually no cultural material was collected below Level 10 in Unit 1 and Level 7 in Unit 2, we continued taking flotation samples through Level 11 of both units to increase the chances of recovering cultural materials if they were present.

The flotation samples produced a significant amount of charred maize. In Unit 1, numerous Zea mays cupules, cob fragments, and kernel fragments were recovered from Levels 3, 4, 6, 7, and 9. In Unit 2, one cupule and two kernel fragments were found in Level 2 , and a cob segment was found in Level 7 . The nine kernel fragments found in Unit 1, Level 7 have been submitted for radiocarbon dating.

\section{Interpretation}

We believe that Zone 4 represents the original surface colluvium on which T413 was built. This is supported by the abundance of calcium carbonate throughout the layer, implying its great age. The depth of this layer is a result of the deposition of colluvium from the slopes above, prior to terrace construction. Zone 3 is the terrace fill that was deposited on top of the original surface colluvium to construct T413. The berm wall fill which supports the terrace fill was not visible in the excavation units, because Unit 1 was placed too far away from the terrace edge. A layer of finer material would then have been deposited on top of the terrace fill to complete the occupation surface. Due to its compact nature, it is possible that Zone 2 represents this original occupation zone. Aeolian and colluvial processes then deposited the thin $(3 \mathrm{~cm})$ layer of fine silty loess which covers the occupation surface. The activities of insects and other natural agents probably account for the subsurface cultural materials in T413. The presence of insects in the excavation units, as well as the presence of cultural debris even in the original colluvium layer below the terrace, supports this notion. Through these processes, artifacts originally deposited on the occupation surface have migrated downward through the subsurface levels over time. 


\section{Appendix 2: Cerro los Torres Feature Descriptions (94-287)}

\section{Introduction}

Cerro los Torres is one of two additional cerros de trincheras tested during the 1998 season. This site is located approximately 40 kilometers south of Cerro Juanaqueña along the Rio Casas Grandes. Cerro los Torres is situated on an outlying promontory almost 1.5 kilometers east of the modern riverbed and rises approximately $85 \mathrm{~m}$ above the surrounding floodplain. Cerro los Torres is within eyesight of several other cerros de trincheras, including Cerro el Gallo $7.6 \mathrm{~km}$ to the north and Cerro la Cruz $7.5 \mathrm{~km}$ to the south. Today, most of the land to the south and west of Cerro los Torres is being cultivated by well water irrigation. In addition, much of these modern ejido lands have been modified by the construction of canals and channels across the floodplain of the Rio Casas Grandes.

The vast majority of terraces on Cerro los Torres were situated on the more gently sloping northeastern side of the hill. Rather than facing the floodplain, most of the terraces look east-northeast toward a pass between the Sierra la Escondida and the Sierra Capulin. The terraced portion of this hill occupies approximately 2 ha, concentrated within the upper third of the hilltop. Altogether there are over $2 \mathrm{~km}$ of terraces and walls, and perhaps 20 rock rings. One of the most striking aspects of this site is the macrofeature which surrounds the complex of features, defining a rough circle about $240 \mathrm{~m}$ in diameter centered on the summit. On the south, west, and northwest this feature is a $500 \mathrm{~m}$ long continuous constructed cobble berm resembling contiguous terraces in some places, but angling across the hillslope in other places. On the northeastern slope of the hill the macrofeature is defined by some of the lowermost terraces, which are contiguous with one another to form a more or less continuous feature 300 $\mathrm{m}$ in length. The area defined by this feature is about 4 ha in size and includes some of the steepest areas of the hill, areas which do not have constructed features. Virtually all of the terraces and rock rings at Cerro los Torres are consistent with the types, shapes, and sizes that are those found at Cerro Juanaqueña.
Artifact Distribution

Lithic artifacts are common on Cerro los Torres, although the artifact scatter is not as dense as at Cerro Juanaqueña. In addition to debitage, cores, hammerstones, drills or awls, bifaces, and projectile points were noted. Combining collections made during Minnis and Whalen's project in 1996 and those made by us in 1998, a total of 19 projectile points have been collected from this site. Of these, 11 appear to be dart points, 7 arrow points, and 1 specimen could be either. Manos and metate fragments also occur on the site, but not in the frequencies observed at Cerro Juanaqueña. These seem to correspond with the general morphology of those found at Cerro Juanaqueña. Most of these fragmentary metates appear to be formed from a pinkish andesite. One stone bowl was collected in 1998. A number of pictographs thought to date from the Medio period ( A.D. 11501400) are found on the southern and western rim of the summit.

Local people report that some years ago a plain redslipped ceramic vessel was found in a pile of cobbles on the summit of the hill. Near this pile of rocks we have found seven small sherds in a $3 \mathrm{~m}$ diameter area. One of these was an incised brownware and three others had a reddish brown slip. The other five were plain brownwares. An eighth sherd was found $100 \mathrm{~m}$ away on the northern slope of the hill.

\section{Terrace 1}

\section{Description}

Terrace 1 (T1) was selected because of its central location as well the presence of an ashy gray soil near the berm wall in the center of the terrace (Figures 22 and 23). One basin metate fragment and a mano fragment were also recorded in association with this feature. $\mathrm{T} 1$ faces toward the east and rests approximately 


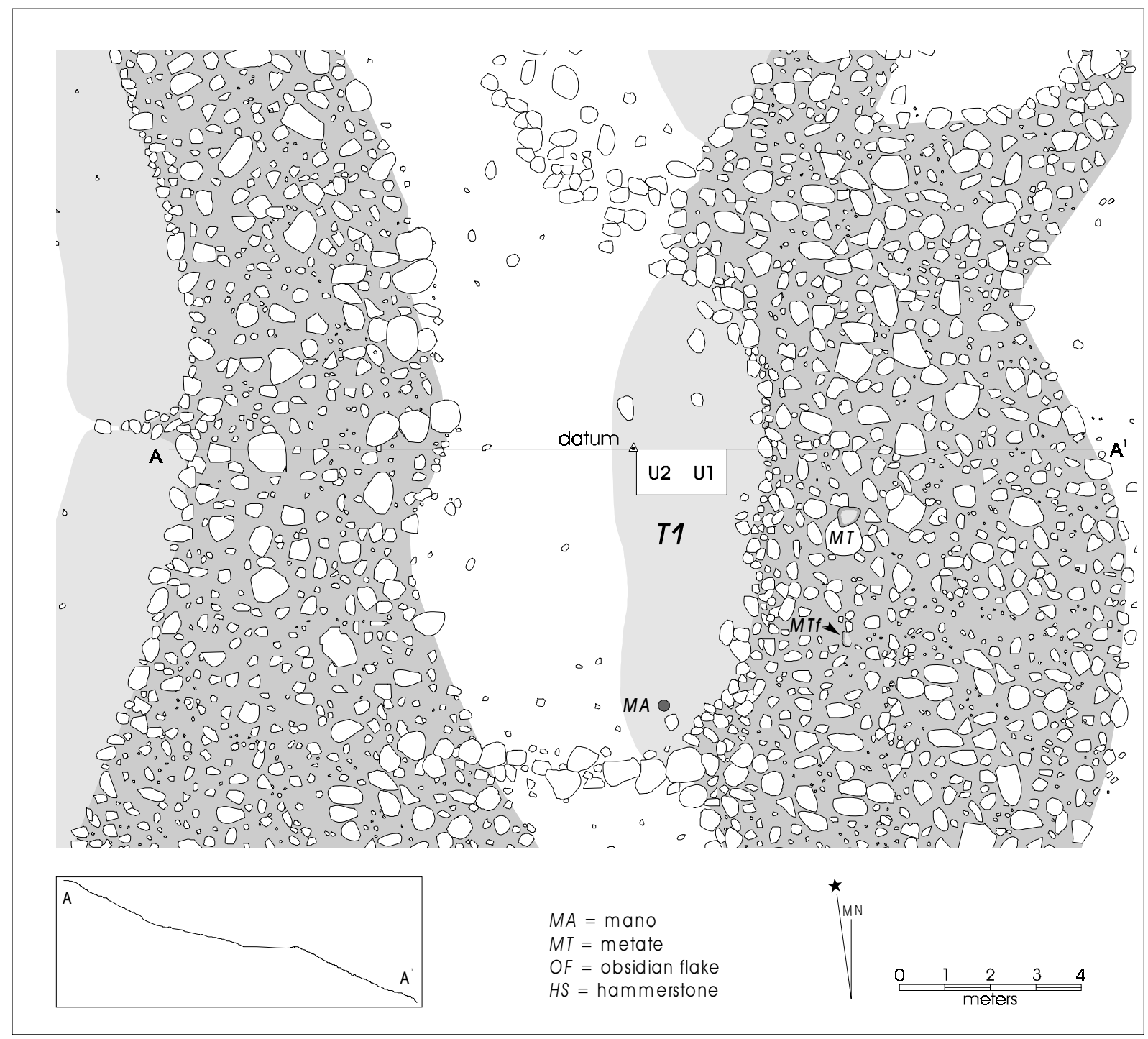

Figure 22. Plan view of T1, Cerro los Torres.

7 meters below the summit on the northeastern side of the hill. The walls of this short oblate terrace stretch approximately 13 meters from north to south and vary in width from 3 to 6 meters.

\section{Excavation Strategy}

All surface artifacts on T1 were recorded and mapped and a cross section of the feature was established. The center of the terrace was selected for testing after ashy soil was observed emanating from a disturbance just below the apex of the berm. Initially, two $1 \mathrm{~m}$ by $1 \mathrm{~m}$ excavation units were placed on the terrace surface, but a third unit $1 \mathrm{~m}$ by $.5 \mathrm{~m}$ in size was later added to recover additional botanical remains.

Units 1 and 2 were placed near the front edge of the terrace and were excavated simultaneously in $10 \mathrm{~cm}$ levels. Ashy soil was encountered in the eastern portions of Unit 1 and another unit (Unit 3) was added to recover additional flotation samples. Unit 3 further aided in the interpretation of the construction sequence by exposing a more complete profile. The terrace fill on $\mathrm{T} 1$ proved to be moderately deep and bedrock was first encountered at $50 \mathrm{~cm}$ below the surface in Unit 2. Bedrock continues to dip toward the east and reaches a maximum depth of $98 \mathrm{~cm}$ below the surface in Unit 3. Excavations ceased when bedrock was exposed. 


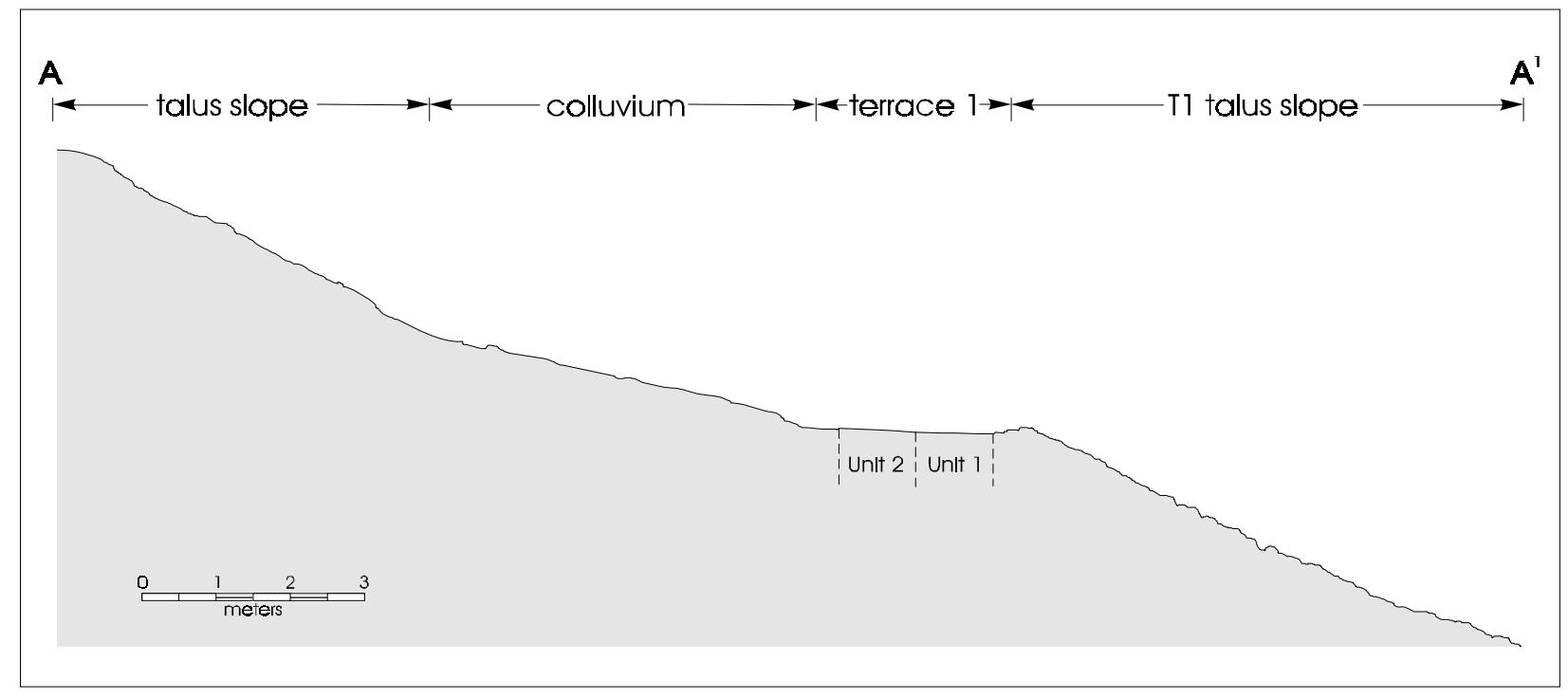

Figure 23. Cross-section of T1, Cerro los Torres.

\section{Stratigraphy}

These units proved to be $20-40 \mathrm{~cm}$ deeper than similar slopes on Cerro Juanaqueña. The lowermost zone of artificial construction (Zone 5) consists primarily of larger cobbles $(>10 \mathrm{~cm})$ concentrated in Units 1 and 3 and sweeps upward to the surface in the east (Figure 24). This zone appears to represent the back slope of berm construction and is distinguished by high quantities of ashy debris in the lower levels of Units 1 and 3 . These large cobbles are supported by a loose small cobble $(<10 \mathrm{~cm}) /$ silty loam matrix $(10 \mathrm{YR} 4 / 3)$ and directly overlay a thin layer $(\approx 5 \mathrm{~cm})$ of pre-occupational colluvium. Directly west of this zone is thick $(30-50 \mathrm{~cm})$ zone (Zone 4$)$ of loose cobble/silty loam matrix (10YR 4/3) which extends across Units 1 and 2. This material is distinguishable from the berm fill only in the fewer number of very large cobbles inclusions in the matrix. Zone 3 is a matrix of silty loam which overlays the unconsolidated fill of Zones 4 and 5 .Zone 2 is relatively free of large or medium cobbles $(>5 \mathrm{~cm})$ and likely represents the ancient living surface. Much of this stratum is clearly laminated and there is a distinctive increase in artifact density in the lower portions of this zone. Finally, the top 3-8 cm across the surface of the units (Zone 1) consists of a fine colluvium wash which appears to have been deposited in post occupational periods.

\section{Samples and Artifacts}

Artifact and botanical remains seem to follow a similar pattern as seen at some of the tested terraces at Cerro Juanaqueña. Lithic debitage peaks in Units 1 and 2 between 10 and $20 \mathrm{~cm}$ below the terrace surface but remains fairly consistent at all depths of the berm wall in Unit 3. Faunal remains were primarily recovered from the lower levels of Units 1 and 3 and appears to conform to a pattern of downward migration through the crevices of the berm wall.

An abundance of botanical remains were recovered at Cerro los Torres and includes in descending order of frequency; Zea mays, cheno-am, Eragrostis intermedia, Physalis, Gramineae, Atriplex, Leguminosae, and Euphorbia sp. A Zea mays cupule and three kernel fragments recovered from level 8 of Unit 3 were sent to INSTARR Laboratories at the University of Colorado for radiometric dating.

\section{Interpretation}

The construction sequence of T1 likely occurred in one brief phase. T1 appears to have been constructed directly upon thin colluvial surface of this eastern facing slope. The berm wall appears to have been formed first by the piling large and medium sized cobbles to form an oblate arc. It is possible that the ashy sedi- 


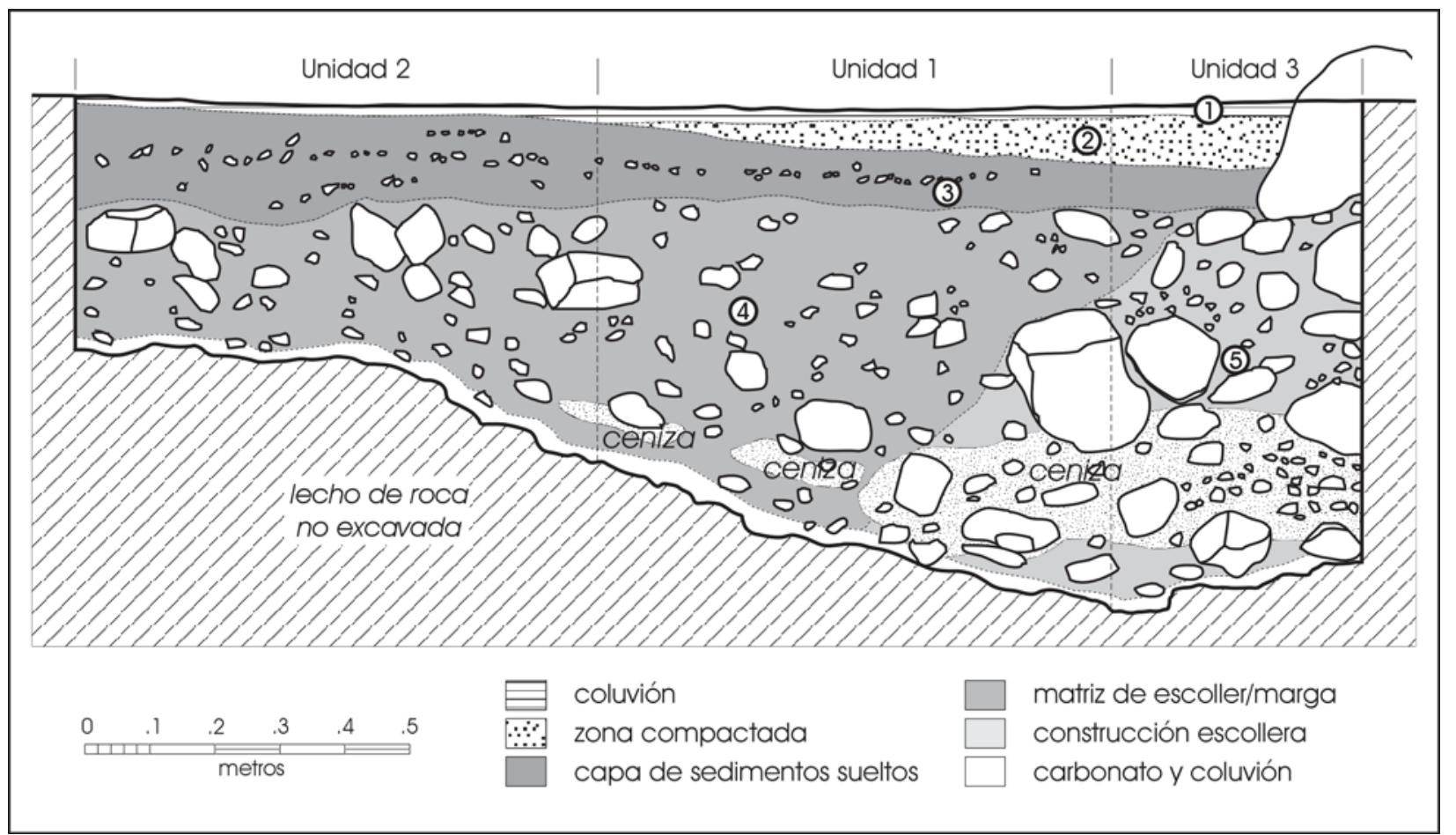

Figure 24. Unit 1, 2, and 3 profiles, Cerro los Torres.

ment and bones recovered in the lower levels of Units 1 and 3 were incorporated into the fill at this time, but there is no direct evidence that this was the case. The area directly behind the berm wall was next filled in and leveled with smaller cobbles and sediment from the surrounding hillside, forming a surface upon which daily activities could be carried out. Surface artifacts indicate that this terrace as well as others nearby were used for a variety of activities including lithic reduction and the grinding of seeds and/or other plant parts.
Although no clear living surfaces or hearths were found during excavations of T1, the presence of large quantities of ash, bone, and botanical remains deep within the berm wall indicate that such activities did occur on this terrace. 


\section{Appendix 3: Cerro Vidal Feature Descriptions (95-392)}

\section{Introduction}

Cerro Vidal rises $120 \mathrm{~m}$ above the Rio Piedres Verdes which runs along the western base of the hill. Cerro Vidal is a volcanic hill and is principally composed of basalt. The cerro lies near the junction of the Piedres Verdes and the Rio Palanganas which unite to form the Rio Casas Grandes. Cerro Vidal is some 30 kilometers upstream and southwest of Cerro los Torres and is 70 $\mathrm{km}$ south of Cerro Juanaqueña. The Sierra la Breña one of the northernmost ranges of the Sierra Madre Occidental towers above the sprawling plains approximately $10 \mathrm{~km}$ to the west. Cerro Vidal is within eyesight of several other cerros de trincheras and related features, including Cerro la Tinaja $12.4 \mathrm{~km}$ to the northwest, Cerro Moctezuma $5.0 \mathrm{~km}$ to the northeast, and Cerro la Boca de San Diego $3.8 \mathrm{~km}$ to the southeast. The floodplain immediately below the site is farmland irrigated by water diverted from the river and carried along a system of acequias. The features are on the summit of the hill, as extend down its gently sloping northern, eastern, and southern sides. The western side of the hill drops steeply to the river and was apparently too steep to be conducive to construction of terraces.

The prehistoric constructions are centered on the highest point of the hill and are very comparable to the terraces and rock rings described for Cerro Juanaqueña and Cerro los Torres. There are approximately $2.3 \mathrm{~km}$

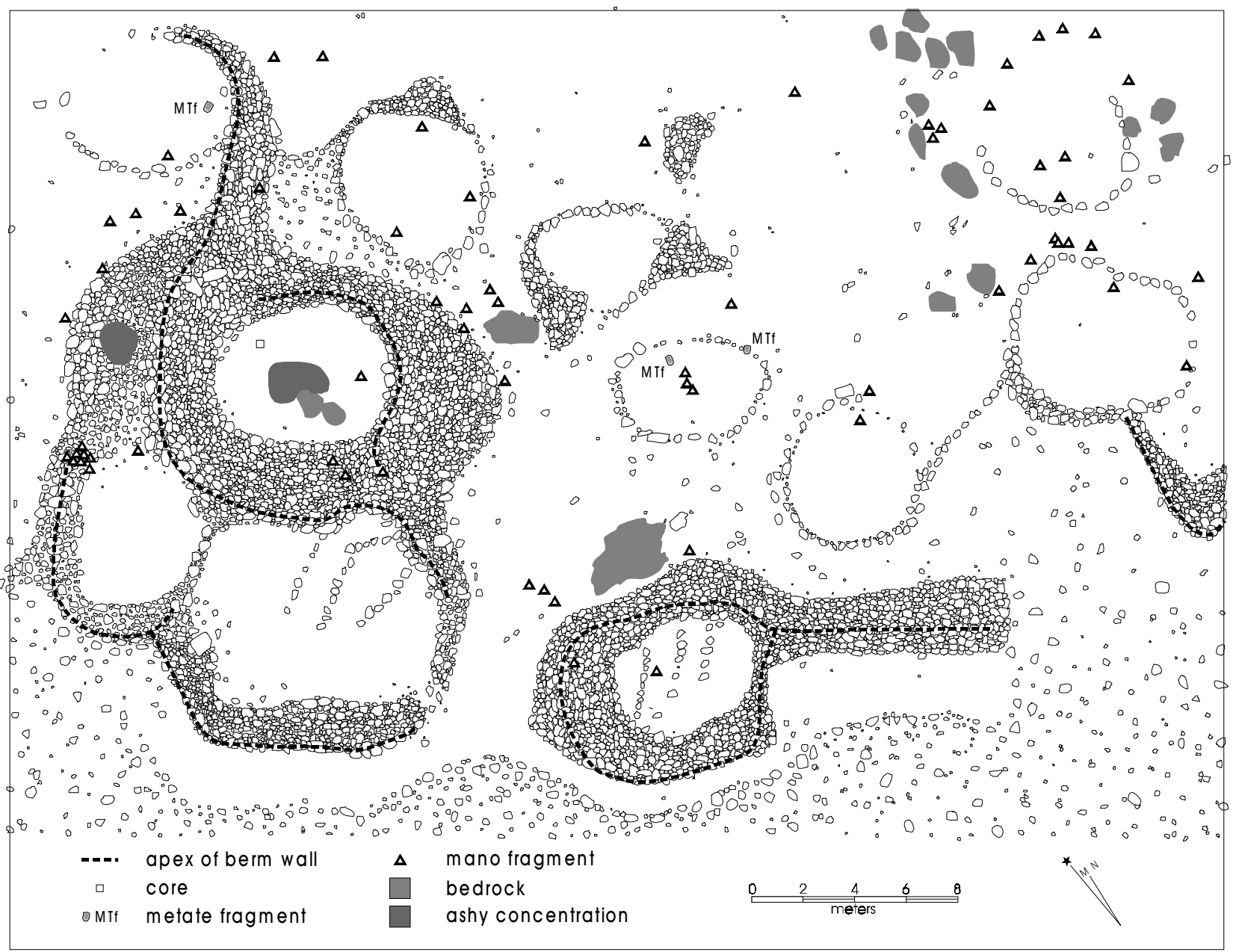

Figure 25. Rock-Ring Features on north end of Cerro Vidal. 
of terrace and wall on Cerro Vidal, and perhaps as many as 40 rock rings (Figure 25). Although the terraces at Cerro Vidal were constructed as individual arcs, like those at the other cerros de trincheras in Chihuahua, at this site the coalescence of individual terraces into macrofeatures is especially obvious. The overall plan of the site has the form of a series of six concentric ovals, defined by macrofeatures. The outermost of these is over 500 meters long and encloses an area of about 3.4 ha. Within this area are 25 rock rings, another 15 rock rings occur outside the main terrace complex.

\section{Artifact Distribution}

Although the range of artifacts at Cerro Vidal is similar to that at Cerro Juanaqueña, the artifact density on the surface of this site is noticeably lower. In addition to debitage we have noted cores, hammerstones, drills or awls, bifaces, cruciforms, and projectile points. The projectile points include 10 dart points and 6 smaller projectile points which may be arrow points. No pottery has been found at this site. Few metate fragments were noted, but there is a large number of small, expedient manos.

\section{Terrace 20}

\section{Description}

T20 is a relatively small arc-shaped terrace and part of a larger macro-feature which faces northeast toward Cerro Moctezuma. This feature is similar to terraces found at Cerro Juanaqueña in overall form and is constructed from local basalt. The terrace wall is approximately $10 \mathrm{~m}$ long and the surface area of the terrace is approximately $25 \mathrm{~m}^{2}$. T20 was selected because of the large number of ground stone fragments on the terrace surface, its location near the peak of the hill, and because terrace deposits appeared to be rather deep.

\section{Excavation Strategy}

The central objective was to recover carbonized material for $\mathrm{C}_{14}$ dating to determine the period of occu- pation at Cerro Vidal. All surface artifacts on T20 were recorded and mapped, and a cross section of the feature was drawn. Units 1 and 2 were laid out approximately $20 \mathrm{~cm}$ behind the berm wall on the terrace surface and excavated simultaneously in $10 \mathrm{~cm}$ increments. Unit 2 reached bedrock first at $60 \mathrm{~cm}$ below the surface and a maximum depth occurred in Unit 1 at $85 \mathrm{~cm}$ below the surface.

\section{Stratigraphy}

Four stratigraphic zones were identified in the southern profile of Units 1 and 2. Zone $4 \mathrm{~b}$ is the lowest stratum and consists of a thin, broken layer of colluvium and calcified cobbles spread across both units just above bedrock. Zone $4 \mathrm{a}$ is composed of a very loose, fine, silty loam matrix with some cobble and pebble inclusions. This matrix has a dark grayish brown color (10YR 4/3) and differs from terraces excavated at Cerro Juanaqueña by its relatively low percentage of large and medium sized $(>5 \mathrm{~cm})$ cobbles. Zone $4 \mathrm{a}$ varies in thickness from $35 \mathrm{~cm}$ in Unit 2 to $60 \mathrm{~cm}$ in Unit 1 and appears to represent the bulk of terrace fill for T20. Zone 3 is a more compact layer of brown to dark brown (10YR 4/3) silty loam sediments and ranges from $8 \mathrm{~cm}$ to $13 \mathrm{~cm}$ thick. Large and medium cobbles are virtually absent from this stratum. It appeared likely from observations in the field that the top of this layer could signify the occupational surface. Zone 2 directly overlies Zone 3 and contains a higher percentage of pebble inclusions $(>5 \%)$. Zone 2 averages $\approx 10 \mathrm{~cm}$ thick and is a dark grayish brown (10YR 4/2) color. Zone $1 \mathrm{~b}$ is a very hard-packed platy matrix of silty clay loam and is a grayish brown (10YR 5/3) color. Finally, Zone 1a includes the top 1-3 cm across the surface of the units and consists of a fine colluvium wash likely deposited in post occupational periods.

\section{Samples and Artifacts}

The recovery of lithic debitage at Cerro Vidal was relatively high $(>100)$ through $60 \mathrm{~cm}$ below the surface where counts began to steadily decrease with each additional level. There was no pronounced difference of lithic artifacts between the two units. Little bone was present. 
Ashy material and several tiny flakes of charcoal were observed in the lower levels of Unit 1 during excavations. Botanical remains recovered from levels 5 and 7 of Unit 1 included 3 copules of Zea mays and two Cheno-am seeds. The Zea mays cupules were sent to INSTARR Laboratory at the University of Colorado to undergo radiometric dating (see Table 4).

\section{Interpretation}

Because Units 1 and 2 were set back $20 \mathrm{~cm}$ behind the berm wall, very little of the wall construction was exposed during excavation. Consequently, very little information was gained as to the formation processes of T20. The compaction of sediments in zone 3 suggest that it may have been a living surface. Several medium sized cobbles $(5-10 \mathrm{~cm})$ were found to rest at the top of Zone 3 and were likely placed there during the period of occupation or immediately there after. 


\section{Appendix 4: Modern Vegetation Found in the Janos Area, September 4-6, 1998}

\section{Cerro Juanaqueña}

Agave aff. palmeri Engelm

Agave sp.

Albutilon malacum S. Watson

Alliona incarnata L.

Allionia sp.

Aloysia wrightii

Amaranthus palmeri Wats.

Apodanthera undulata Gray

Aristida ternipes Cav. var. ternipes

Aristolochea aff. Wrightii Seem

Asclepias aff. Brachystephana Torr.

Bebbia juncea (Benth.) Greene

Bouteloua curtipendula

Bouteloua Rothrockii Vasey

Brickellia

Cevallia sinuata Lag.

Chenopodium incanum (Wats.) Heller

Chloris virgata Swartz

Croton lindheimerianus Scheele

Cucurbita digitata Gray

Dalea wrightii Gray

Dasylirion wheeleri Wats.

Digitaria californica (Bentham) Henrard

Ephedra

Eragrostis intermedia Hitchc.

Eriogonum spp.

Erioneuron pulchellum (H.B.K.) Tateoka

Ferocactus

Fouquieria

Gutierrezia

Hibiscus denudatus Benth.

Iva ambrosiaefolia (Gray) Gray

Jatropha macrorhiza Benth.

Kallstroemia grandiflora Torr.

Lycium?

Macroptilium atropurpureum (D.C.) Urban

Manihot davisiae Croizat

Matricaria

Mentzelia multiflora (Nutt.) Gray

Muhlenbergia Porteri Scribner ex. Beal

Nicotiana obtusifolia Mart. \& Gal.
Opuntia (cholla)

Opuntia (prickly pear)

Opuntia leptocaulis

Physalis hederaefolia Gray

Pleuraphis mutica Buckley

Proboscidea

Prosopis glandulosa Torr.

Senna bauhinoides Gray

Senna wislenzenii Gray

Setaria macrostachya H.B.K.

Solanum eleagnifolium

Sporobolus wrightii Munro ex. Scribner

Stipa comata

Talinum aurantiacum Engelm.

Talinum paniculatum (Jacq.) Gaertn.

Trianthema portulacastrum L.

Tridens muticus (Torrey Nash.) var. muticus

Trixis californica Kellogg

Unknown shrub

Yucca (narrow leaf)

Zizyphus obtusifolia (Torr. \& Gray) Gray

\section{Floodplain and River Terraces}

Agave aff. palmeri Engelm

Allionia sp.

Amaranthus palmeri Wats.

Ambrosia spp.

Ambrosia trifida

Atriplex canescens

Atriplex wrightii Wats.

Baccharus sarothroides

Cephalanthus occidentalus L.

Chenopodium sp.

Chloracantha spinosa (Benth.) Nason

Chloris virgata Swartz

Cucurbita digitata Gray

Cucurbita foetidissima

Cucurbita sp. (possibly palmeri)

Datura

Echinochloa colonum (L.) Link

Erigeron

Helianthus annuus

Ipomoea spp. 
Juglans

Kallstroemia grandiflora Torr.

Mentzelia multiflora (Nutt.) Gray

Opuntia (cholla)

Opuntia (prickly pear)

Populus

Portulaca halimoides L.

Proboscidea

Prosopis glandulosa Torr.

Salix spp.

Salsola pestifer

Solanum eleagnifolium

Solanum sp.

Sorghum halapense

Sphaeralcea angustifolia (Cavanilles) G. Don

Sporobolus airoides (Torrey) Torrey

Trianthema portulacastrum L.

Verbesina

Xanthium

Yucca (narrow leaf)

\section{Modern Agricultural Fields}

Amaranthus palmeri Wats.

Atriplex wrightii Wats.

Cephalanthus occidentalus L.
Chenopodium sp.

Chloracantha spinosa (Benth.) Nason

Cucurbita foetidissima

Eragrostis cilianensis (All) Vign. Lutati ex Janchen

Helianthus annuus

Hibiscus sp.

Ipomoea spp.

Mentzelia multiflora (Nutt.) Gray

Polygonum

Robinia pseudoacacia L.

Solanum eleagnifolium

Sorghum halapense

\section{La Palotada}

Anemopsis californicus (Nutt.) Hook \& Am

Berula erecta (Huds.) Cov.

Cyperus odoratus L.

Datura

Fraxinus

Nastursium

Polygonum

Scirpus pungens

Typha

Wislizenia refracta Engelm.

Xanthium 


\section{References Cited}

Bayham, F. E.

1982 A Diachronic Analysis of Prehistoric Animal Exploitation at Ventana Cave. Doctoral dissertation, Arizona State University, University Microfilms, Ann Arbor.

Binford, L. R.

1978 Nunamiut Ethnoarchaeology. Academic Press, New York.

Broughton , Jack M.

1994a Declines in Mammalian Foraging Efficiency During the Late Holocene. Journal of Anthropological Archaeology, 13:371-401.

1994b Late Holocene Resource Intensification in the Sacramento Valley, California: The Vertebrate Evidence. Journal of Archaeological Science, 21(4):501-514.

Fish, Suzanne

1999 Pollen Results from the 1997 Field Season at Cerro Juanaqueña. Manuscript on file at the Center for Archaeological Research, San Antonio, Texas.

Fish, S. K., P. R. Fish, and C. E. Downum

1984 Hohokam Terraces and Agricultural Production in the Tucson Basin. In Prehistoric Agricultural Strategies in the Southwest, edited by S. K. Fish and P. R. Fish, pp. 55-71. Anthropological Research Papers No. 33. Arizona State University.

Fritz, Gayle

1984 Identification of Cultigen Amaranth and Chenopod from Rockshelter Sites in Northwest Arkansas. American Antiquity 49:558-572.

Greene, J. L. and T. W. Matthews

1976 Faunal Study of Unworked Mammalian Bones, Appendix 5. In The Hohokam: Desert Farmers and Craftsmen, edited by E. W. Haury, pp. 367-373. University of Arizona Press, Tucson.

Hard, Robert L. and John R. Roney

1998a A Massive Terraced Village Complex in Chihuahua, Mexico Dated to 3000 Years Before Present. Science, March 13, 1998.

1998b Continuing Archaeological Investigations of Late Archaic Cerros de Trincheras Sites in Chihuahua, Mexico. Grant Application to the National Science Foundation.

Hard, Robert J., Raymond P. Mauldin, and Gerry R. Raymond

1996 Mano Size, Stable Carbon Isotope Ratios, and Macrobotanical Remains as Multiple Lines of Evidence of Maize Dependence in the American Southwest. Journal of Archaeological Method and Theory 3: $253-318$.

Hard, Robert J., José E. Zapata, John R. Roney, and Bruce K. Moses

1999 Terrace Construction in Northern Chihuahua, Mexico at 1150 B.C. and the Present. Paper submitted to the Journal of Field Archaeology, under review. 
Houk, Brett and Bruce Moses

1998 Scanning Artifacts: The Use of a Flatbed Scanner to Image Three-Dimensional Objects. SAA Bulletin 16(3):36-39.

Huckell, Bruce B.

1995 Of Marshes and Maize: Preceramic Agricultural Settlements in the Cienega Valley, Southeastern Arizona, Anthropological Papers of the University of Arizona No. 59, The University of Arizona Press, Tucson.

1996 Middle to Late Holocene Stream Behavior and the Transition to Agriculture in Southeastern Arizona. In Early Formative Adaptations in the Southern Southwest, edited by B. Roth. Monographs in World Archaeology No. 25, Prehistory Press, Madison, Wisconsin.

Keely, L. W.

1996 War Before Civilization. Oxford University Press, New York.

Kelly, Robert L., and Lawrence C. Todd

1988 Coming into the Country: Early Paleoindian Hunting and Mobility. American Antiquity 53:231-244.

Kent, S.

1991 Mobility Strategies and Site Structure. In The Interpretation of Archaeological Spatial Patterning, edited by E. M. Kroll and T. D. Price, pp. 33-59, Plenum Press, New York.

Krider, P. Reen

1998 Paleoclimatic Significance of Late Quaternary Lacustrine and Alluvial Stratigraphy, Animas Valley, New Mexico. Quaternary Research 50:283-289.

Lang, R. W. and A. H. Harris

1984 The Faunal Remains from Arroyo Hondo Pueblo, New Mexico: A Study in Short Term Subsistence Change. Arroyo Hondo Archaeological Series, Vol. 5, School of American Research, Santa Fe.

Metcalfe, S. E., A. Bimpson, A. J. Courtice, S. L. O’Hara, and D. M. Taylor

1997 Climate Change at the Monsoon/Westerly Boundary in Northern Mexico. Journal of Paleolimnology 17:155-171.

Nordt, Lee

1998 Geomorphology Results from the 1997 Field Season at Cerro Juanaqueña. Manuscript on file at the Center for Archaeological Research, San Antonio, Texas.

Olsen, J. W.

1982 Prehistoric Environmental Reconstruction by Vertebrate Faunal Analysis, Grasshopper Pueblo. In Multidisciplinary Research at Grasshopper Pueblo, Arizona, edited by W. A. Longacre, S. J. Holbrook, and M. W. Graves, pp. 63-72, University of Arizona Press, Tucson.

Schmidt, Kari M. And Jennifer Nisengard

1998 Fauna from Cerro Juanaqueña. Paper presented at the 62nd Annual Meeting of the Society for American Archaeology, Seattle. 
Schmidt, Kari M.

1999 Logistical Mobility and Faunal Remains: A Diachronic Study from the San Simon Valley of Southeastern Arizona. Masters thesis on file, University of Oklahoma, Norman.

Shackley, M. Steven

1998 Source Provenance of Archaeological Obsidian from Cerro Juanaqueña, Cerro Vidal, and Cerro Los Torres, Northwestern Chihuahua. Manuscript on file at the Center for Archaeological Research, San Antonio, Texas.

Spaulding, W. G., and L. Graumlich

1986 The Last Fluvial Climatic Episodes in the Deserts of Southwestern North America. Nature 320:441444.

Szuter, C. R. and F. E. Bayham

1989 Sedentism and Animal Procurement Among Desert Horticulturalists of the North American Southwest. In Farmers as Hunters: The Implications of Sedentism, edited by S. Kent, pp. 80-95, Cambridge University Press, Cambridge, England.

Tagg, M. D.

1996 Early Cultigens from Fresnal Shelter, Southeastern New Mexico. American Antiquity, 61:311-324.

Van Devender, Thomas R.

1990 Late Quaternary Vegetation and the Climate of the Chihuahuan Desert, United States and Mexico. In Packrat Middens: The Last 40,000 Years of Biotic Change, edited by J. L. Betancourt, T. R. Van Devender, and P. S. Martin, pp. 104-133. University of Arizona Press, Tucson.

1995 Desert Grassland and History: Changing Climates, Evolution, Biogeography, and Community Dynamics. In The Desert Grassland, edited by Mitchel P. McClaran and Thomas R. Van Devender, pp. 68-99. University of Arizona Press, Tucson.

Van Devender, Thomas R., R. S. Thompson, and J. L. Betancourt

1987 Vegetation History in the Southwest: The Nature and Timing of the Late Wisconsin-Holocene Transition. In North America and Adjacent Oceans During the Last Deglaciation, edited by W. F. Rudiman and H. E. Wright, Jr., pp. 323-352. Geological Society of America, Boulder.

Van Devender, Thomas R., and R. D. Worthington

1977 The Herpetofauna of Howell's Ridge Cave and the Paleoecology of the Northwestern Chihuahuan Desert. In Transactions of the Symposium of the Biological Resources of the Chihuahuan Desert Region, United States and Mexico, edited by R. H. Wauer and D. H. Riskind, pp. 85-106. National Parks Service, Transactions and Proceedings Series No. 3, Washington D. C.

Vierra, Bradley J.

1993 Archaic Hunter-Gatherer Mobility in the American Southwest. In Across the Colorado Plateau: Anthropological Studies for the Transwestern Pipeline Expansion Project, edited by T. W. Burchett, B. J. Vierra, and K. L. Brown, pp. 385-397. Office of Contract Archaeology and the Maxwell Museum of Anthropology, University of New Mexico, Albuquerque. 
1996 Late Archaic Settlement, Subsistence and Technology: An Evaluation of Continuity vs. Replacement Arguments for the Origins of Agriculture in the Northern Southwest. Paper presented at the Conference on the Archaic Prehistory of the North American Southwest, University of New Mexico, Albuquerque.

Waters, Michael R.

1992 Principles of Geoarchaeology: A North American Perspective. University of Arizona Press, Tucson.

Whalen, Michael, and Paul E. Minnis

1994 Informe Tecnico Final al Consejo de Arqueología, Instituto Nacional de Antropología e Historia del Proyecto El Sistema Regional de Paquime,Chihuahua, Mexico. Manuscript on file at the University of Tulsa, Oklahoma. 